\title{
II. The Dialogue of CEE Constitutional Courts in the Era of Constitutional Pluralism
}

Izabela Skomerska-Muchowska*

\section{Introduction}

The main function of any constitutional court is to protect an institutional integrity of a state based on principles of democracy and rule of law and constitutionally granted rights. When performing these tasks, courts do no operate in isolation. In the $21^{\text {st }}$ century the globalisation tendencies are stronger than ever. The practice of national constitutional courts has been equally affected. As guardians of national constitutions, when conducting the control over the constitutionality of legal acts issued within a given legal system, they can no longer rely solely on a national law and ignore the international context. The universal fundamental values like democracy, the protection of basic human rights and freedoms, and the application of fundamental principles of law are protected not only at a national constitutional level, but also by international law both universally and regionally. In Europe, two legal regimes are of special importance in this regard: first, the system of the European Convention for the Protection of Human Rights and Fundamental Freedoms (the ECHR or the Convention) whose

* Dr iur., Assistant Professor, Department of European Constitutional Law, Faculty of Law and Administration, University of Lodz, Poland. 
provisions are interpreted and applied by the European Court of Human Rights (ECtHR). The second regime binding upon the Member States of the European Union is based on the Treaties of the European Union (the Treaty on the European Union TEU) and the Treaty on Functioning of the European Union (TFEU) and by the Charter of the Fundamental Rights of the European Union, whose uniform interpretation and application is ensured by the Court of Justice of the European Union (the CJEU). The two treaty-based regimes, constituted in a national like way by written meta-norms or codified secondary rules and based on normative foundations similar to state constitutions, are recognised by academia as constitutional legal orders. ${ }^{1}$ The constitutional courts of each of these systems, the ECtHR and the CJEU respectively, exercise compulsory jurisdiction over disputes that arise in the respective legal regimes as organs responsible for authoritative interpretation of the constitution and for preservation of coherence of a given legal systems. The courts' authority to interpret and apply the regimes' laws is final. ${ }^{2}$

The legal reality of overlapping constitutional orders, both special regimes of international law and national constitutional orders, can be explained through the lens of constitutional pluralism. The concept has emerged in the context of discussions about relations between legal orders in a complex, partly overlapping and not necessarily hierarchical legal reality. The notion identifies the phenomenon of a plurality of constitutional sources, which creates a context for potential constitutional conflicts between different constitutional orders to be solved in a non-hierarchical manner. Such context affects the role of all national courts and the character of adjudication. ${ }^{3}$ Specifically, constitutional courts do not only apply international law but act as guardians of constitutional orders holding a position of ultimate authority within it. As such, the courts are confronted with other constitutional orders whose provisions are applicable within their scope of jurisdictions. Due to a special position of constitutional courts and their engagement in exchange of views and concepts with other courts (both international and foreign national) the area of their practice seems to be the most useful one for a research aiming at exploration of the role of judicial dialogue in a pluralistic legal reality. In such reality, undoubtedly, judicial activity cannot be reduced to a mechanical application of law in the form of judicial syllogism. For this reason in recent years the role of judges has become increasingly relevant. Judicial dialogue understood as a reference to a foreign (international

1 See: A.S. Stone Sweet, H. Keller, 'The Reception of the ECHR in National Legal Orders', [in:] H. Keller, A.S. Stone Sweet (eds), A Europe of Rights. The Impact of the ECHR on National Legal Systems (Oxford University Press 2008), p. 3.

2 Cf. A. Stone Sweet, 'Constitutionalism, Legal Pluralism and International Regimes' (2009) 16 Indiana Journal of Global Legal Studies, p. 621.

3 See: M.P. Maduro, 'Contrapuntal Law: Europe's Constitutional Pluralism in Action', [in:] N. Walker (ed.), Sovereignty in Transition (Hart Publishing 2003), p. 501; M. Cartabia, 'Europe and Rights: Taking Dialogue Seriously' (2009) 5 European Constitutional Law Review, p. 5. 
or national) case law in constitutional interpretation ${ }^{4}$ is the main mechanism of coexistence of the highest courts in a legal constellation constructed in a heterarchical manner.

The aim of this contribution is to explore a phenomenon of judicial dialogue of the CEE constitutional courts from the point of view of constitutional pluralism. We will examine whether these courts act as international courts responsible for effective application of international rule of law and its development within the 'global community of courts' through engagement in judicial dialogue, as described by A.-M. Slaughter. ${ }^{5}$ After a short review of the concept of constitutional pluralism the practice of CEE constitutional courts will be examined. First, we will identify interlocutors of CEE constitutional courts and then the phenomenon of judicial dialogue in specific fields of law will be discussed. The last part is devoted to limits of judicial dialogue visible against the background of the identified and analysed case law.

\section{The Concept of Constitutional Pluralism}

\subsection{From Dualism to Pluralism - a Conceptual Framework}

Legal pluralism is commonly recognised as a new idea of the end of the $20^{\text {th }}$ century. The Kelsian monistic concept of unity of international and municipal law has by now been recognised as inadequate for description of mutual relations between international and national law. ${ }^{6}$ At the same time, the dualistic approach may be recognised as an intellectual basis for the concept of legal pluralism with regard to autonomous natures of national and international legal orders. ${ }^{7}$ The du-

4 Cf. V. Perju, 'Constitutional Transplants, Borrowing, and Migrations', [in:] M. Rosenfeld, A. Sajó (eds), The Oxford Handbook of Comparative Constitutional Law (Oxford University Press 2012), p. 1304.

5 See: A.-M. Slaughter, 'A Global Community of Courts' (2003) 4 Harvard International Law Journal, p. 191.

6 Cf. A. Bogdandy von, 'Pluralism, direct effect, and the ultimate say: On the relationship between international and domestic constitutional law' (2008) 6 International Journal of Constitutional Law, p. 397; J. Nijman, A. Nollkaemper, 'Beyond Divide', [in:] idem (eds), New Perspectives on the Divide Between National and International Law (Oxford University Press 2007), p. 341; G. Ulfstein, 'The International Judiciary', [in:] J. Klabbers, A. Peters, G. Ulfstein (eds), The Constitutionalisation of International Law (Oxford University Press 2009), p. 142. However opposite position by P. Allott, The Emerging Universal Legal System in New Perspectives on the Divide Between National and International Law (Oxford University Press 2007).

7 The dualist or pluralist view on the relationship between domestic and international law was presented by H. Triepel and then developed inter alia by D. Anzilotti. See: R. Collins, 'Classical 
alistic concept of a relation between international and national law is based on the presumption of autonomy of both systems. Such autonomy is related to the fact that the norms of legal orders in question have various addressees and the consequent divergent relations require different form of regulations. ${ }^{8}$ However, this does not mean that international law is deprived of any domestic significance. On the contrary, national courts as State organs fulfil a crucial function in execution of international obligations by a State. ${ }^{9}$ Since, on the one hand, international law is addressed to States and regulates their relations, and, on the other hand, national law governs relations within a State territory and is addressed to subjects under its jurisdiction, international law has been recognised as applicable by national judges as far as they are authorised to do so by a national legal order, usually, through national constitutional provisions. Thus, dualism, as defined by G. Gaja, is not a single concept but rather a set of concepts based on common grounds. According to this author,

[t]he main feature of dualism appears to be that international law and municipal laws are viewed as separate legal systems, which may be defined as self-contained, because within each system the only existing rules are those that are part of the system. Rules which are not created within the system may nevertheless be relevant for the system if they are referred to by a rule included in the system. ${ }^{10}$

legal positivism in international law revisited', [in:] J. Kammerhofer, J. D’Aspremont (eds), International Legal Positivism in a Post-Modern World (Oxford University Press 2014), p. 24.

8 D. Ancillotti, argued, that international and municipal law "are enacted by different wills: international law stems from the collective will of several States, while rules of municipal law are always the expression of the will of a State, or better of the will belonging to a State, if one does not wish to prejudge the well-known controversy on the binding nature of custom, which many jurists consider as law which is not State law, while nobody doubts that it belongs to municipal law. [...] if norms of international law only regulate relations among States, and give rights and duties only to States, it is impossible that disputes governed by international law ever come as such before national judicial authorities. One could therefore state that on principle these authorities never take a decision which is immediately based on a rule of international law." Quotation after G. Gaja, 'Positivism and Dualism in Dionisio Anzilotti' (1992) 3 European Journal of International Law, p. 123.

9 As D. Ancilotti further pointed out "norms of international law do not have any intrinsic or necessary inadequacy for being observed and applied by national courts. Courts are State organs and everybody knows that implementation - taking the word in its wide meaning - of international law may only take place through these organs. The State is certainly no fiction, but is nevertheless an abstraction, as it is a collective body represented as a unity - it is a collective will, which is shaped and expressed by one or several individual wills, an activity that requires and sets forth a sum of individual activities. Thus, the State expresses its will and acts through those to which these functions pertain and which we call its organs. So also rights and duties that international law gives to a State may be exerted and respectively accomplished only through its organs." Quotation after: ibidem, p. 123.

10 G. Gaja, 'Dualism: A Review', [in:] J. Nijman, A. Nollkaemper (eds), New Perspectives on the Divide between National and International Law (Oxford University Press 2007), p. 53. 
The development of international law, and especially the adoption of international instruments aiming at conferral of rights upon individuals and creation of international self-contained regimes equipped with judicial bodies having jurisdiction to adjudicate in cases of individual rights on the one hand and phenomenon of the so-called "globalisation of national constitutions"11 on the other, questions a relationship between international law (or special regimes of international law) and national legal orders.

The above question of relationship between international law and national law is currently explored by academia through the lens of legal pluralism. It is conceived of as a landscape of overlapping and interacting cycles of international, European and national legal orders. ${ }^{12}$ The notion of legal pluralism was defined for the first time in regard to the EU as a reaction to the judgement of the German Federal Constitutional Court. N. MacCormick thus wrote:

\begin{abstract}
The most appropriate analysis of the relations of legal systems is pluralistic rather than monistic, and interactive rather than hierarchical. The legal system of Member States and their common legal system of EC law are distinct but interacting systems of law, and hierarchical relationships of validity within criteria of validity proper to distinct systems do not add up to any sort of all-purpose superiority of one system over another. ${ }^{13}$
\end{abstract}

Both dualism and legal pluralism are based on autonomy of legal orders. In case of dualism clear distinction was made between effectiveness of international law in municipal legal orders and international responsibility for performance of international obligations. There is no hierarchy between international and national law or between international tribunals and national courts. Even if the aim of international norm is to confer rights upon individuals, such obligation is enforceable under international law exclusively at the international level. ${ }^{14}$ The concept of legal pluralism presupposes that there exist overlapping legal orders, thus a particular situation can be governed by norms belonging to different legal systems. Thus constitutional pluralism, born within autonomous, directly applicable normative system of the $\mathrm{EU},{ }^{15}$ is understood as a plurality of institutional normative orders,

11 A. Peters, 'The Globalization of State Constitutions', [in:] J. Nijman, A. Nollkaemper, New Perspectives on the Divide Between National and International Law (Oxford University Press 2007), p. 251.

12 Since the article is focused on role of national constitutional courts the question of relations between regimes of international law and general international law is not discussed. N. MacCormick, 'The Maastricht Urteil: Sovereignty Now' (1995), p. 1, European Law Journal, p. 259. to notify defendants of their right to consular assistance "can be carried out in various ways. The choice of means must be left to the United States" Germany $v$ United States of America (ICJ, 27 June 2001), para. 125. See also: Avena and Other Mexican Nationals, Mexico v United States of America (ICJ, 31 March 2004), para. 141.

15 R. Barents, 'The Precedence of EU Law from the Perspective of Constitutional Pluralism' (2009), p. 5; European Constitutional Law Review, p. 421; Priban I., 'Asking the Sovereignty 
each with a functioning constitution conceived of as a body of higher-order norms establishing and conditioning relevant governmental powers. ${ }^{16}$ The EU legal order makes its own independent constitutional claims, which exist alongside the continuing claims of states. ${ }^{17}$

The debate on constitutional pluralism started but did not end with the EU. The concept of constitutionalisation of international law understood as "the process of (re)organization and (re-)allocation of competence among the subjects of the international legal order, which shapes the international community, its value system and enforcement" ${ }^{18}$ and even the idea of creation of "global constitutional community" ${ }^{19}$ further exposes the understanding of constitutional law and blurs the direct link between constitutional law and the nation state. The constitutional claim of international law is based mainly on developments of the end of the $20^{\text {th }}$ century and the beginning of $21^{\text {st }}$ century. Namely, the recognition of jus cogens norms and erga omnes obligations under international law provoked the discussion concerning internal hierarchy of international law, public law analogies and, in consequence, the proclamation on a constitutional nature of the international legal order as a normative system based on common values of the international community. ${ }^{20}$

The specific manifestation of the constitutionalisation of international law is the expansion of international human rights, which are perceived by some authors as

Question in Global Legal Pluralism: From "Weak" Jurisprudence to "Strong" Socio-Legal Theories of Constitutional Power Operations' (2015) 28 Ratio Juris, p. 33.

Although commonly used the idea as such remains Problematic. See: M. Avbelj, J. Komárek, 'Four Visions of Constitutional Pluralism' (2008) 4 European Constitutional Law Review, p. 524; N. Walker, 'The Idea of Constitutional Pluralism' (2002), p. 65, Modern Law Review, p. 317; N. Walker, 'Post-Constituent Constitutionalism? The Case of the European Union', [in:] M. Laughlin, N. Walker (eds), The Paradox of Constitutionalism: Constituent Power and Constitutional Form (Oxford University Press 2007), p. 247. Some authors distinguish between legal and constitutionalism and pluralism e.g. N. Krisch, points out that "[t]he contest between constitutionalism and pluralism has so far largely lacked a common basis - pluralists have typically made their case on analytical grounds, while constitutionalists have mostly turned to the normative sphere. So whereas pluralism seems to provide a strong (though contested) interpretation of the current, disorderly state of post-national law, constitutionalism - if not yet realized today - appears as the more attractive vision for the future." N. Krisch, 'The case for pluralism in post-national law', [in:] G. de Búrca, J.H.H. Weiler, The Worlds of European Constitutionalism (Oxford University Press 2011), p. 203.

17 N. Walker (n. 17), p. 337.

18 E. de Wet, 'The International Constitutional Order' (2006) 55 International \& Comparative Law Quarterly, p. 51.

19 A. Peters, 'Membership in the Global Constitutional Community', [in:] J. Klabbers, A. Peters, G. Ulfstein (eds), The Constitutionalisation of International Law (Oxford University Press 2009), p. 153.

20 Cf. E. de Wet (n. 19), pp. 57-63; J. Klabbers, T. Piiparinen, 'Normative Pluralism: An Exploration', [in:] iidem (eds), Normative Pluralism and International Law: Exploring Global Governance (Cambridge University Press 2013), p. 13. 
international constitutional rights. ${ }^{21}$ The universality of human rights is, however, questioned. ${ }^{22}$ Thus although human rights constitute fundamental value of international law, pluralistic interaction took place predominantly in case of a specific treaty based regimes. ${ }^{23}$ The ECHR is the most prominent example. The jurisprudence of the ECtHR interpreting specific human rights on the basis of the concept of the Convention as a living instrument strongly influences also the development of national constitutional rights.

\subsection{Institutional Dimension of the Constitutional Pluralism - the Role of Judicial Dialogue}

In the legal environment described above it is impossible to avoid conflicts arising between European, international, or national political and legal institutions. Since there is no hierarchy between competing legal orders each of them is based on its own secondary rules (if one was to use Hart's terminology). ${ }^{24}$ The existence of multiple poles of constitutionalism equipped with an ultimate judicial body results in jurisdictional competition between international courts (in our case mainly the CJEU and the ECtHR) and national constitutional courts. Both constitutional and international courts perceive their own basic documents (national constitutions, on the one hand, and international treaties, on the other) as supreme law and claim ultimate authority to interpret them. Such judicial or interpretative competition distinguishes constitutional courts form other national courts. While all other national judges face the problem of multiple loyalties and dual or multiple preliminarily since they belong to plural legal orders, ${ }^{25}$ constitutional courts are, first of all, guardians of national constitutions. By definition, therefore, their main task covers authoritative interpretation of the constitution and thus also the preservation of the coherence of the legal order. Nevertheless, even when preforming the role of servants of the constitution, they are faced with authority of international courts carrying out exactly the same function within treaty-based regimes. Since national constitutions, directly or indirectly, insert internation-

21 A. Peters (n. 12), p. 167.

22 See: R.A. Macdonald, 'Pluralistic Human Rights? Universal Human Wrongs?', [in:] R. Provost, C. Sheppard (eds), Dialogues on Human Rights and Legal Pluralism (Springer 2013), p. 15.

23 However one must agree that fragmentation of international law on human rights can be seen as the way of development of universal human rights law: "it is through fragmentation that human rights can aspire to universality." C.I. Fuentes, R. Provost, S.G. Walker, 'E Pluribus Unum - Bhinneka Tunggal Ika? Universal Human Rights and the Fragmentation of International Law', [in:] R. Provost, C. Sheppard (eds), Dialogues on Human Rights and Legal Pluralism (Springer 2013), p. 38.

24 H.L.A. Hart, The Concept of Law (Oxford University Press 1997).

25 See more: G. Martinico, 'Multiple loyalties and dual preliminarity: The pains of being judge in a multilevel legal order' (2012) 10 I-CON 871. 
al and European law into national legal orders ${ }^{26}$ constitutional judges must determine not only the position of international and European legal orders within national system but also their own relation with international courts. In both so-called monistic and dualistic states international law is applicable (in the broad meaning of the term including any form of invocability) within the limits determined by a national constitution as interpreted by a particular constitutional court. It means that regardless of whether a given legal system is called 'monistic' or not, in fact the constitutional courts act always as dualistic or pluralistic since even in so called 'monistic' states a national constitution is perceived as a means of general incorporation of international law to domestic legal order. At the same time a constitution as the supreme law of a land establishes limits for effectiveness of international law within a domestic system. The difference between those two, as it was already indicated, lays in the fact that in case of dualism, international law as well as decisions of international courts are invoked simply to ensure that international obligations of the state are fulfilled. In case of constitutional pluralism national and international laws are interconnected by common values, which create the platform for dialogue. However, it does not mean that in the pluralistic world conflict of legal orders is excluded. It is minimalized due to the axiological consistency of legal orders, but not fully eliminated.

The pluralistic approach does not provide a clear answer as to who is to act as a final arbiter in case of conflict. In a given case a judge is to employ different forms of judicial techniques in order to find the best legal solution. The role of a dialogue, especially the dialogue between highest (constitutional) courts cannot be overestimated in formation of a common understanding of law. The pluralist approaches to the international legal order claim to preserve space for contestation, resistance and innovation, and to encourage tolerance and mutual accommodation. ${ }^{27}$ The relationship between the orders is now horizontal rather than vertical, that is to say, heterarchical rather than hierarchical..$^{28}$ As the result, the main institutional relations between legal orders are based on mutual recognition and respect between authorities.

At the same time, because of globalisation, courts of different states are faced with similar legal problems. The increasing availability of foreign judicial decisions and the development of bilateral and multilateral cooperation of constitutional courts, at least on the European level, create a unique possibility of interaction also between national constitutional courts. As the result, both vertical and horizontal dialogues have become the main tool of development of the international rule of law. It must be noted in that regard that constitutional courts, in contrast to other national courts, operate mainly on matters

26 See: contribution by Wyrozumska in this volume.

27 See: G. de Búrca, 'The ECJ and the international legal order: a re-evaluation', [in:] G. de Búrca, J.H.H. Weiler, The Worlds of European Constitutionalism (Oxford University Press 2011), p. 105. 
of principle. In Habermas's understanding using a constitutive interpretation in order to deliver acceptable solution of a legal problem, do constitutional courts not only build up the understanding of a legal order as a "system of rules structured by principles", ${ }^{29}$ but also develop their own concept of "value jurisprudence".

The legal and constitutional pluralism require an expansion of the scope of legal arguments to be employed by courts and an increased focus on systemic and teleological reasoning resulting in increasing contextualization of judicial reasoning. ${ }^{30}$ The new legal challenges before courts do not require a construction of new judicial techniques, but rather a recognition that law is a dynamic structure and requires the reflexive methodology of adjudication. Constitutional courts have a leading role in judicial dialogue within pluralistic legal environment. The participation in a dialogue requires not only sufficient openness for arguments of other interlocutors, but also self-reflection and self-determination. This leads to a gradual change of the language. The sovereignty arguments are supplemented by constitutional identity ones. Although this term remains subjective and ambiguous, ${ }^{31}$ it can be considered as a symbolic barrier where the influence of others finishes and self-consideration within a specific community starts.

The resolution of conflicts though dialogue does not necessarily bring a clearcut simple solution and requires an on-going process of mutual accommodation. The heterarchical nature of legal pluralism entails "specific language of dialogue and encounter, give and take, criticism and self-criticism. Dialogue means both speaking and listening, and that process reveals both common understandings and real differences. Dialogue does not mean everyone at the table will agree with one another. Pluralism involves the commitment to being at the table - with one's commitments." 32

In the subsequent parts of this paper we will explore how the CEE constitutional courts consider their own role in the pluralistic environment and how they

29 J. Habermas, Between Facts and Norms. Contributions to a Discourse Theory of Law and Democracy, translated by William Rehg (The MIT Press 1996), pp. 253, 262.

30 M.P. Maduro, 'Courts and Pluralism: Essay on a Theory of Judicial Adjudication in the Context of Legal and Constitutional Pluralism', [in:] J.L. Dunoff, J.P. Trachtman (eds), Ruling the World? Constitutionalism, International Law, and Global Governance (Cambridge University Press 2009), pp. 356, 361.

31 See: M. Rosenfeld, The Identity of the Constitutional Subject: Selfhood, Citizenship, Culture, and Community (Routledge 2010); idem, 'Is Global Constitutionalism Meaningful or Desirable?' (2014) 25 European Journal of International Law, p. 177; A. Śledzińska-Simon, 'Constitutional identity in 3D: A model of individual, relational, and collective self and its application in Poland' (2015) 13 I-CON 124.

32 K. Lachmayer, 'The Possibility of International Constitutional Law. A Pluralistic Approach towards Constitutional Claw and Constitutional Comparison', [in:] P. Riberi, K. Lachmayer (eds), Philosophical or Political Foundation of Constitutional Law? Perspectives in Conflict (Nomos Publishing 2014), p. 283. 
interact with other international and foreign courts. We will search for the position at the discussion table the CEE courts take and the commitments they will bring to it.

\section{Judicial Dialogue in Practice of the CEE Constitutional Courts}

\subsection{The Actors of Judicial Dialogue}

In multi-centric or poly-contextual environment of European human rights protection system it is desirable that constitutional courts of all States parties to the Convention consider, directly or indirectly, the case law of the ECtHR. Similarly the jurisprudence of the CJEU is significant not only for the Member States of the EU, but to all the States parties to the ECHR because of interactions between both international courts. In addition, case law of foreign domestic courts may be relevant, if it contributes to legal evolution of human rights protection standard or principles of democratic state based on rule of law.

The aim of this part of the paper is to explore the scope of judicial dialogue in CEE in both institutional terms and so taking into consideration both international and cross-national aspects of it. We will analyse how and why constitutional courts of Czech Republic, Hungary, Lithuania, Poland, Russia and Ukraine enter into conversation with other courts, and how they build court-to-court relations.

\subsubsection{The Dialogue with the European Court of Human Rights}

The ECHR is the most frequently referred to international court in the CEE States. The ECtHR is an international treaty binding upon these states. Its formal position in national legal orders is determined by national constitutions. ${ }^{33}$ Since the relation of national constitutional courts and the ECtHR are based simultaneously on the international treaty and national regulations, this kind of dialogue is described in literature as a vertical ${ }^{34}$ or a mandatory one. ${ }^{35}$

Different factors influence implementation of the ECHR and of the case law of the ECtHR, in domestic legal orders. The Venice Commission identified

33 See: contribution by Wyrozumska in this volume.

34 See: A.-M. Slaughter, 'A Typology on Transjudicial Communication' (1994) 29 University of Richmond Law Review, p. 99.

35 See: M. Bobek, Comparative Reasoning in European Supreme Courts (Oxford University Press 2013), p. 21. 
a range of them. From the domestic perspective what matters are: the conceptualization of the relation between international and domestic legal orders and international law, a position of human rights treaties within domestic legal orders' hierarchy, direct and indirect effect and the interpretation clauses in domestic constitutions and legislation enabling the reception of human rights treaties and decisions of monitoring bodies into the domestic legal order (legal possibility of reopening the procedure after the ECtHR decision indicating the violation of the Convention). ${ }^{36}$ Another identified factor is the position of human rights instruments related to their specific aim. They are to ensure the effective protection of human rights, which means that main beneficiaries of human rights treaties are not states but individuals. ${ }^{37}$ It is also important to notice that the Protocol 11 to the ECHR ensures compliance with the obligations arising from the Convention under individual applications subject solely to the exhaustion of domestic remedies, which includes the constitutional complaint lodged before the constitutional court if applicable. Thus the decision of a constitutional court can be subject to review by the ECHR. ${ }^{38}$ The position of the ECHR within the ECtHR system is also vital. According to Art. 32 ECHR, the ECtHR poses exclusive and final jurisdiction with regard to interpretation of the Convention. In line with Art. 46 States are to abide by the final judgments of the ECtHR. ${ }^{39}$ On that basis the ECtHR has developed specific powers to give maximum effect to its case law, like pilot judgments procedure, which encourages domestic constitutional courts to consider the practice of the Court in a systemic manner. Finally, in CEE States all national constitutions in question have been adopted with the perspective of accession to the European Convention thus there is a strong focus on conformity or even unity of constitutionally granted rights with those provided for by the Convention. Human rights and rule of law standards were 're-imported' from international law into the legal orders of CEE States. ${ }^{40}$ In the transformation period, the interpretation of national constitutions in the light

36 European Commission for Democracy through Law (Venice Commission) Report on the Implementation of International Human Rights Treaties in Domestic Law and the Role of Courts adopted by the Venice Commission at its $100^{\text {th }}$ plenary session (Rome, 10-11 October 2014) on the basis of comments by Ms. Veronika Bílková (Member, Czech Republic), Ms. Anne Peters (Substitute Member, Germany), Mr. Pieter van Dijk (Expert, The Netherlands), Study No. 690/2012 (Strasbourg, 8 December 2014), p. 5. Ibidem, p. 17 Cf. A. Voßkuhle, 'Multilevel Cooperation of the European Constitutional Courts. Der Europäische Verfassungsgerichtsverbund' (2010) 6 European Constitutional Law Review, p. 175. See: European Commission for Democracy through Law (Venice Commission) Report On The Implementation of International Human Rights Treaties in Domestic Law and the Role of Courts, Study No. 690/2012, CDL-AD(2014)036 (Strasbourg, 8 December 2014).

40 See: A. Peters, 'Supremacy Lost: International Law Meets Domestic Constitutional Law' (2009) 3 Vienna Online Journal on International Constitutional Law, p. 170. 
of the ECtHR seemed to be treated as a proof of systemic changes in CEE ${ }^{41}$ and was to confirm the belonging of the CEE states to the community of democratic states based on the rule of law. All of the above factors lead to the recognition of the case law of the ECtHR as an indicator of the common European standard of protection of human rights and, as such, also as the substantive source of constitutional values. ${ }^{42}$

In the Czech Republic before 2001, international human rights treaties, as an only category of incorporated international treaties, had been granted a status equal to the Constitution within the Czech legal order. ${ }^{43}$ After the $2001 \mathrm{Eu}$ ro-amendment of the Constitution ${ }^{44}$ the incorporation clause was extended to all ratified and promulgated international treaties and treaties on human rights were deleted form the formal definition of the constitutional order. ${ }^{45} \mathrm{Howev}$ er, the Czech Constitutional Court declared in 2002 that human rights treaties ratified prior to the constitutional amendment would not be affected by the change in the regulation and sustained the 'constitutional law quality' granted to the ECHR by the legal system of the Czech Republic. ${ }^{46}$ In the judgment

41 Cf. R. Prochazka, Mission Accomplished. On Founding Constitutional Adjudication in Central Europe (Central European University Press 2002), p. 17; A. Czarnota, M. Krygier, W. Sadurski (eds), Spreading Democracy and the Rule of Law? The Impact of EU Enlargement for the Rule of Law, Democracy and Constitutionalism in Post-Communist Legal Orders, Constitutional Evolution in Central and Eastern Europe: Expansion and Integration into the EU (Springer 2006); L. Hammer, F. Emmert (eds), The European Convention on Human Rights and Fundamental Freedoms in Central and Eastern Europe (Eleven International Publishing 2012). It is worth notice that although Lithuania has ratified the ECHR in 2000 already in 1991 the Reconstituent Seimas of the Republic of Lithuania made an official statement that "it will respect and honestly fulfill all the obligations established by the European Convention for the Protection of Human Rights and Fundamental Freedoms of 4 November 1950", Declaration of the Seimas of the Republic of Lithuania on the Obligations of the Republic of Lithuania arising from the Convention for the Protection of Human Rights and Fundamental Rights of 4 November 1950, 5 October 1991, 17/94 on the confidentiality of legal counselling (Lithuanian Constitutional Court, 18 November 1994), quotation after A. Čepas, 'Preface', [in:] Human Rights in Lithuania (NAUJOS SISTEMOS 2005). See also: judgements of Polish Constitutional Court K 1/92 (Polish Constitutional Court, 20 October 1992). If not indicated otherwise translations of the judgments of the Polish Constitutional Court comes from the website of the Court <http://trybunal.gov.pl/en/> accessed between March 2012 and May 2016.

42 Cf. M. de Visser, Constitutional Review in Europe (Hart Publishing 2015) 229.

43 See: detailed analysis P. Mikeš, 'Czech Courts and International Law' (2011) 2 Czech Yearbook of International Law, p. 289.

44 Constitutional Act 395/2001 Coll.

See: P. Štruma, 'Human Rights in a New EU Member State: The Czech Example', [in:] R. Arnold (ed.), Universalism of Human Rights (Springer 2013), p. 357.

46 The Constitutional Court held that: "[t]he inadmissibility od changing the substantive requirements of a democratic state based on the rule of law also contains an instruction to the Constitutional Court, that no amendment to the Constitution can be interpreted in such a way that it would result in limiting an already achieved procedural level of protection for fundamental rights and freedoms [...]. The guarantee of a general 
of 11 November 2006 the Court confirmed a special position of international human rights treaties, and stressed that the case law of the ECHR as the authoritative interpretation of the ECtHR must be taken into account by all state organs. ${ }^{47}$

After 2010 amendment of the Hungarian Constitution, the Constitutional Court in the judgment of 12 July 2011 stressed the importance of international agreements on human rights as a minimum standard of protection and emphasised its own obligation of due consideration of case law of the Strasbourg court stemming from pacta sunt servanda principle. ${ }^{48}$ The Court applied a clearly du-

incorporation norm within the Constitution, and the rejection thereby of dualistic concept of the relationship between international and domestic law, cannot be interpreted to mean that ratified and promulgated international agreements on human rights and fundamental freedoms are removed as a reference point for the purpose of the evaluation of domestic law by the Constitutional Court with derogative effect. Therefore, the scope of the concept of constitutional order cannot be interpreted only with regard to Art. 112(1) of the Constitution, but also in view of Art. 1(2) of the Constitution and ratified and promulgated international agreements on human rights and fundamental freedoms must be included within it." Judgement PI. ÚS 36/01 (Czech Constitutional Court, 25 June 2001). See also judgements: I. ÚS 752/02 (Czech Constitutional Court, 15 April 2003) and Pl. ÚS 44/02 (Czech Constitutional Court, 24 June 2003). If not indicated otherwise translations of judgments of the Czech Constitutional Court come from the website of the Court <http://www.usoud.cz/en/decisions/> (access: between March 2014 and May 2016).

47 I. ÚS 310/05 (Czech Constitutional Court, 11 November 2006). The Court held that: "[t]he immediate applicability of international treaties also includes the obligation of Czech courts and other public authorities to take into account the interpretation of these treaties by international tribunals as authorities called upon to pronounce authoritatively on the interpretation of international treaties. This of course also applies to the interpretation of the ECHR by the ECtHR. The relevance of the ECtHR jurisprudence achieved constitutional law quality in the Czech Republic. ECtHR decisions are for the Czech Republic and for public authorities on its territory binding in an individual case, which also comes from Art. 46(1) of the ECHR. [...] For the reasons mentioned above, however, have public authorities a general duty to take into account the interpretation of the ECHR carried out by the ECtHR. [...] Public authorities, in the first place then the courts, are therefore obliged to take into account the case law of the ECtHR as well as in the cases where decisions concerned the Czech Republic as well as in the cases that concerned another Member State of the ECHR when these cases were, by its nature, significant also for the interpretation of the ECHR in the Czech context" (translation after Mikeš P., 'Country Report Czech Republic' 10. In 2010 the Czech Constitutional Court repeated this statement and not only included broad analysis of the ECtHR case law into argumentation but also pointed out that there is an obligation of any national court of the Czech Republic to consider practice of the European Court. Otherwise "courts ignorance or lack of knowledge may lead to the State liability of violation of the Convention", II. ÚS 862/10 (Czech Constitutional Court, 19 May 2010).

48 Case 61/2011 (Constitutional Court of Hungary, 12 July 2011): "There are some fundamental rights the essential content of which is formulated in the same manner in the Constitution and as in an international treaty (e.g. the International Covenant on Civil and Political Rights and the European Convention on Human Rights). In such cases, the level of protection 
alistic approach towards the Convention as an incorporated international treaty. The Court used this reasoning in subsequent decisions where the Court employed formula to justify consideration of the decisions of ECtHR in subsequent judgements:

in the course of examining the petition, the Constitutional Court took account of the case law of the European Court of Human Rights [...]. Hungary as a state party joined the Convention on the protection of human rights and fundamental freedoms promulgated in Act XXXI of 1993 [...], therefore the Constitutional Court applies as the minimum requirements of protecting rights in the course of elaborating the Hungarian constitutional standards the aspects found in the judicial practice of ECHR on the interpretation of the Convention. ${ }^{49}$

It means that due to the incorporation of the ECHR into Hungarian legal order, the Court recognises the Convention as a part of constitutional standard of protection of human rights (although the minimal one) and the case law of the ECtHR is considered as a part of the Convention. ${ }^{50}$

The Lithuanian Constitutional Court in 1995 in case concerning ratification of the ECHR, stated that the Convention

is a peculiar source of international law, the purpose of which is different from that of many other acts of international law. This purpose is universal, i.e. to strive for universal and effective recognition of the rights declared in the Universal Declaration of Human Rights and to achieve that they were observed while protecting and further implementing human rights and fundamental freedoms. With respect to its purpose, the Convention performs the same function as the constitutional guarantees for human rights, because the Constitution establishes the guarantees in a state and the Convention - on the international scale. That is why it is very significant to evaluate and establish the relation between the Convention and the Constitution. ${ }^{51}$

of fundamental rights guaranteed by the Constitutional Court cannot be in any case lower than the level of the international protection namely that of the European Court of Human Rights. Consequent of the principle of pacta sunt servanda the Constitutional Court is bound to follow the Strasbourg jurisprudence and the level of protection of fundamental rights which is thereby defined, even if such a turn could not be deduced necessarily from its' own 'precedent-decisions'” translation after Kovács P., 'International Law in the Recent Jurisprudence of the Hungarian Constitutional Court: Opening of a New Tendency?', [in:] A. Seibert-Fohr, M.E. Villiger (eds), Judgments of the European Court of Human Rights - Effects and Implementation (Nomos 2014), p. 251.

49 Hungarian Constitutional Court cases: $1 / 2013$ (I. 7.) AB, 22/2013 (VII. 19.) AB, 7/2014 (III. 7.) AB.

50 See: detailed discussion by N. Chronowski, T. Drinóczi, I. Ernszt, 'Hungary', [in:] D. Shelton (ed.), International Law and Domestic Legal Systems. Incorporation, Transformation and Persuasion (Oxford University Press 2011), p. 278.

51 Case 22/94 (Lithuanian Constitutional Court, 24 January 1995) on the Convention for the Protection of Human Rights and Fundamental Freedoms, para. 23. If not indicated otherwise translations of judgments of the Lithuanian Constitutional Court come from the website 
The Court stressed that the legal system of the Republic of Lithuania is based on the principle of primacy of the Constitution and that the conflict situation is possible in following circumstances: firstly, if the Constitution established a complete and final list of rights and freedoms and the Convention set forth some other rights and freedoms; secondly, the Constitution prohibited some actions and the Convention defined them as one or another right or freedom; thirdly, some provision of the Convention could not be applied in the legal system of the Republic of Lithuania because it was not consistent with some provision of the Constitution. However, the Court noticed that neither the Constitution nor the Convention contain a complete and final list of human rights and freedoms and that consistent interpretation should be the main tool to avoid conflict. The Court stressed that

\begin{abstract}
the interpretation of the compatibility (relation) of the norms of the Constitution and the Convention must be semantic, logical and not only literal. Literal interpretation of human rights alone is not acceptable for the nature of the protection of human rights. [...] The literal interpretation of legal norms when applied as the only way of interpretation is not acceptable because while interpreting the contents of a legal norm not the particular wording of a certain rule is most significant, but the fact that the text should provide understanding beyond doubt that the instruction is given to certain subjects under certain conditions to act in an appropriate way.
\end{abstract}

The Court thus indicated necessity of employment of dynamic interpretation of human rights guaranteed by the Constitution. Even if the wording of the provision protecting the analogous right differs in the Constitution and in the ECHR, the provisions should be interpreted harmoniously. Consequently, "the provisions of the Convention, which define human rights and freedoms, may be applied along with the constitutional provisions provided they do not contradict the latter." ${ }^{22}$ In 2000 the Lithuanian Constitutional Court expressly recognized the ECtHR's case law as a source in construction of law. The Lithuanian Constitutional Court held that "the jurisprudence of the European Court of Human Rights as a source of construction of law is also important to construction and applicability of Lithuanian law." 53

Thus, the Constitutional Court's case law granted the status of an authoritative source of interpretation of law, first, to the Convention, and, later, to the jurisprudence formed by the ECtHR. ${ }^{54}$

of the Court <http://www.lrkt.lt/en/court-acts/rulings-conclusions-decisions/171/y2016> (access: between March 2014 and May 2016). Ibidem. See also: case 11/99 (Lithuanian Constitutional Court, 7 January 1999). rope - Current Situation and Perspectives", Vilnius 2013, 13. See also: case 26/2014-4/2015 (Lithuanian Constitutional Court, 9 July 2015) on the compliance of certain provisions of the 
In 2012 the Lithuanian Constitutional Court and the ECtHR did not see eye to eye in the context of Paksas case ${ }^{55}$ analysed in depth below (Section II.4). The Lithuanian Court decided in that case that "even though the jurisprudence of the European Court of Human Rights, as a source for construction of law, is important also for construction and application of Lithuanian law, the jurisdiction of the said Court does not replace the powers of the Constitutional Court to officially construe the Constitution." The Court delimited the scope of own competence and powers of the ECtHR and held that:

in itself the judgment of the European Court of Human Rights may not serve as the constitutional basis for reinterpretation (correction) of the official constitutional doctrine (provisions thereof) if such reinterpretation, in the absence of corresponding amendments to the Constitution, changed the overall constitutional regulation (inter alia the integrity of the constitutional institutes - impeachment, the oath and electoral right) in essence, also if it disturbed the system of the values entrenched in the Constitution and diminished the guarantees of protection of the superiority of the Constitution in the legal system.

The Polish Constitutional Court also found that the ECtHR plays an essential role in determining a standard catalogue of fundamental rights and freedoms in a democratic state. ${ }^{56}$ According to the Court:

special role of the European Convention stems from the fact that states-parties to the Convention not only obliged themselves to observe a catalogue of rights and fundamental freedoms included in the Convention but also to comply with the judgments of the European Court of Human Rights which adjudicates on the basis of the Convention and the Protocols that supplement it. The Court's judicial decisions determine the normative contents of rights and fundamental freedoms that are formulated in a compact way, which is understandable, in the Convention and the Protocols. The judicial decisions of the European Court determine common normative contents of rights and fundamental freedoms the regulation of which (also by constitutions) sometimes significantly differs in various states. ${ }^{57}$

rules on the amounts and payment of remuneration to advocates for the provision and coordination of secondary legal aid and detailed discussion of the case law by Kuzborska. Case 8/2012 (Constitutional Court of Lithuania, 22 May 2012).

56 See inter alia Polish Constitutional Court cases: SK 29/04 (6 December 2004), para. VIII.2.; SK 52/08 (9 June 2010), para. III.7.3.2.

57 Case U 10/07 (Polish Constitutional Court, 2 December 2009), para. V.3.2. See also: Case SK 32/14 (Polish Constitutional Court, 22 September 2015). The Court resolved question of constitutionality of provisions of Polish Code of Civil Procedure precluding possibility of reopening of the case in consequence of the ECtHR's decision on infringement of Art. 6 of the ECHR. The Court held that according to the Art. 91(1) of the Polish Constitution the ECHR possesses special legal status. It is part of the Polish legal order and is directly applicable. It is an act of higher legal value than statutes. The content of the Convention is determined by its text as interpreted by the ECtHR. Constitutional status of the Convention covers not 
This means that the Polish Constitution recognizes significance of the ECHR not only as an international treaty but also as an emanation of common European standards (at least at a minimal level) of human rights protection.

It must be also noted that, according to their scope of jurisdiction the Polish and the Czech Constitutional Courts decide about conformity of national law not only with the Constitution but also with international treaties. In cases concerning the ECHR the courts interpret the ECHR in the light of the jurisprudence of the ECtHR. Significantly, in any case the examination of conformity of national provisions with the ECHR is connected with examination of their consistency with a parallel constitutional norm. The fact that the result of the Court's review as to the conformity with both acts is usually exactly the same proves that even if there are two formally separate criteria of legality of national norm they are perceived by the Court as substantively identical. ${ }^{58}$

In the Russian Federation the ECtHR's judgements are recognised as part of legal system of the state on the basis of Art. 15(4) of the Constitution..$^{59}$ According to the Federal Law on ratification of the European Convention for the Protection of Human Rights and Fundamental Freedoms and Protocols thereto Russia recognises the Convention as an integral part of its legal system. The Constitutional Court plays an important role in development of human rights protection in conformity with European standards as established by the Convention and case law of the ECtHR. In 2001, shortly after the accession of Russia to the ECHR, the Constitutional Court stated in Burdov that the Convention

is ratified by the Russian Federation and is in force in all its territory and, consequently, forms part of the domestic legal system. Furthermore, the Russian Federation accepted

only provisions concerning rights and freedoms but also other provisions of the Convention including Art. 6, which obliges state-parties to respect final decision of the ECtHR in any case to which they are parties. This obligation includes prohibition of challenging the infringement of subjective rights decided by the ECtHR and duty of any positive action in order to implement the judgment.

58 See e.g.: as to Art. 8 of the ECHR: K 39/12 (Polish Constitutional Court, 20 January 2015), K 23/11 (Polish Constitutional Court, 30 July 2014), I. ÚS 2482/13 (Czech Constitutional Court, 26 May 2014), Pl. ÚS 24/11 (Czech Constitutional Court, 20 December 2011); as to Art. 10 of the ECHR K 28/13 (Polish Constitutional Court, 21 September 2015); as to Art. 11 of the ECHR: K 5/15 (Polish Constitutional Court, 17 November 2015), K 44/12 (Polish Constitutional Court, 18 September 2014); as to Art. 7 (1), Art. 8 and Art. 18 of the ECHR: K 54/07 (Polish Constitutional Court, 23 June 2009); as to Art. 6 of the ECHR: P 26/11 (Polish Constitutional Court, 15 October 2013), K 6/13 (Polish Constitutional Court, 11 March 2014), K 47/15 (Polish Constitutional Court, 9 March 2016), K 19/11 (Polish Constitutional Court, 3 June 2014), 3 ÚS 1136/13 (Czech Constitutional Court, 27 October 2015); as to Art. 4(1) and (2) and Art. 5(1): II. ús 3626/13 (Czech Constitutional Court, 16 December 2015).

59 Russian constitutional Court cases: 4-П (4 February 1996), 1-П ( 25 January 2001), 2-П (5 February 2007), see also: A.L. Burkov, The Impact of the European Convention on Human Rights on Russian Law. Legislation and Application in 1996-2006 (ibidem-Verlag, Stuttgart 2007), <http://sutyajnik.ru/documents/4237.pdf> (access: between March 2014 and May 2016). 
the jurisdiction of the European Court of Human Rights and undertook to render its law-enforcement practice, including judicial, in full conformity with the obligations flowing from the participation in the Convention and the Protocols thereto. ${ }^{60}$

The Constitutional Court also emphasized that the provisions of the Civil Code of the Russian Federation in that case must "be considered and applied in consistent normative unity with the exigencies of the Convention." ${ }^{\prime \prime}$

In 2007 the Constitutional Court developed the above concept, however, made the reservation in regard to the scope of jurisdiction of the ECtHR. The Russian Constitutional Court held that ${ }^{62}$

[b]y ratifying the Convention for the Protection of Human Rights and Fundamental Freedoms, the Russian Federation recognized the jurisdiction of the European Court of Human Rights as obligatory in questions concerning the interpretation and application of the Convention and Protocols to it in cases of alleged violation by the Russian Federation of provisions of the mentioned instruments. Thereby, like the Convention for the Protection of Human Rights and Fundamental Freedoms, the judgments of the European Court of Human Rights - to the extent that they interpret the substance of the rights and freedoms provided for by the Convention, relying on the generally recognized principles and norms of international law, including the right to access to court and fair justice - are an integral part of the legal system of the Russian Federation. That is why they shall be taken into account by the federal legislator in regulating social relations and by the law-enforcement authorities in applying the respective norms of the law. ${ }^{63}$

The reference to "generally recognised principles and norms of international law" seems to determine both the basis of incorporation of the ECHR into Russian legal order through Art. 15 of the Constitution and limits of applicability of case law of the ECtHR under the Russian Constitution. ${ }^{64}$ At the same time, the Constitutional Court softens the effectiveness of the ECtHR's case law by indication that it must be taken into account while in the previous decision an obligation to ensure full conformity of the national law with the ECHR and case law of ECtHR was declared. ${ }^{65}$ In the discussed case the Court abstained from recognition of challenged provisions of the Code of Civil Procedure on supervisory review, ${ }^{66}$ although

60 Case 1-П (Russian Constitutional Court, 25 January 2001), para. 6.

61 Ibidem.

62 Case 2-П (n. 60).

63 Ibidem, para. 2.1.

64 See: detailed discussion K. Koroteev, S. Golubok, 'Judgment of the Russian Constitutional Court on Supervisory Review in Civil Proceedings: Denial of Justice, Denial of Europe' (2007) 7 Human Rights Law Review, p. 619.

65 Ibidem, p. 624.

66 Supervisory review ('nadzor') is a form of extraordinary appeal against a final judicial decision inherited by Russia and other former communist states from Soviet law. This procedure had been based on the assumption that prosecutors and higher courts supervise the activities 
there was no doubt that they are contrary to the right of a fair trial. Similarly, the above-mentioned reservation was used by the Russian Constitutional Court in the one of the most recent decisions discussed in Section III. 4. to deny execution of the decisions of the ECtHR because of their inconformity with the Russian Constitution and international law.

The position of case law of the ECtHR in the Ukrainian legal order is determined by the Constitution and Art. 17 of the Law of Ukraine on Execution of Judgments and Application of the case law of the European Court of Human Rights, which stipulates the obligatory application of the Convention, as interpreted by the ECtHR, as the source of law. These should be taken into consideration by all judges of Ukraine, including those of the Constitutional Court of Ukraine. Although the Ukrainian Constitutional Court frequently invokes the ECHR in its decisions, ${ }^{67}$ references to case law of the ECtHR are rather rare. Yet, in the last years the frequency of references has been increasing. ${ }^{68}$ The reluctance of the Ukrainian judges to invoke 'external' sources can be explained by the judicial tradition. However, in some cases the implicit influence of the ECtHR practice is evident. The death penalty case ${ }^{69}$ may serve as a flagship example. Even though the Constitutional Court avoided making direct reference to findings of the ECtHR with regard to the non-conformity of death penalty as a type of punishment to the prohibition of torture, inhuman and degrading treatment provided for in Art. 3 of the ECHR, the content of the Ukrainian decision is manifestly inspired by the ECtHR judgment in Soering $v$ United Kingdom. ${ }^{70}$

\subsubsection{The Dialogue with the CJEU}

The dialogue with the CJEU concerns mainly Member States of the EU. In practice of the Russian and the Ukrainian Constitutional Court the case law of the CJEU does not constitute a point of reference. ${ }^{71}$

of lower courts and constitutes a means by which final decisions that are res judicata may be overturned on request of governmental authorities. Ibidem, p. 622.

67 See i.a.: cases indicated in Constitutional Court of Ukraine, National Report XVIth Congress of the Conference of European Constitutional Courts "Cooperation of Constitutional Courts in Europe - Current Situation and Perspectives", Kyiv 2013: 9-rp/97 (Ukrainian Constitutional Court, 25 December 1997) case prior to accession of Ukraine to the ECHR; 19-rp/2004 (Ukrainian Constitutional Court, 1 December 2004); 6-rp/2007 (Ukrainian Constitutional, Court 9 July 2007); 2-rp/2008 (Ukrainian Constitutional Court, 29 January 2008); 20-rp/2008 (Ukrainian Constitutional Court, 8 October 2008); 5-rp/2012 (Ukrainian Constitutional Court, 13 March 2012).

68 See i.a. Ukrainian Constitutional Court cases: 8-rp/2010 (11 March 2010); 17-rp/2010 (29 June 2010); 1-rp/2012 (18 January 2012); 10-rp/2012 (18 January 2012). Case 11-rp/99 (Ukrainian Constitutional Court, 29 December 1999). Soering v United Kingdom, App. no. 14038/88 (ECtHR, 7 July 1989).

71 Cf. Constitutional Court of Ukraine, National Report XVIth Congress, (n. 68) 13, Constitutional Court of the Russian Federation, National Report XVIth Congress of the Conference of European Constitutional Courts "Cooperation of Constitutional Courts in Europe - Current Situation and Perspectives" (Vienna 2014) 23. 
Within the EU legal order the CJEU has exclusive jurisdiction to decide about validity of secondary law and to deliver a legally binding interpretation of EU law norms. One must emphasize that the concept of the 'autonomous nature' of the EU (or the former 'Community') legal order was developed as the result of the judicial dialogue between national courts and the CJEU. The judicial dialogue with constitutional and the highest courts of the Member States started after the formulation of, firstly, the two main principles governing the application of today's EU law in national legal orders such as the direct effect ${ }^{72}$ and the supremacy ${ }^{73}$ of EU law and, secondly, proclamation of auto-referential, complete nature of EU. Importantly, human rights protection must be considered as an inherent part of the EU legal order. ${ }^{74}$ All the above-mentioned legal concepts were formulated by the CJEU in response to inspiring (or even provocative) questions of ordinary courts. As the result, the position of the CJEU within the legal system of the Union has become comparable to the position of constitutional courts within national systems. Thus, ordinary courts became a part of the system of the judicial protection of the EU. In consequence, the powers of constitutional and highest courts have somewhat eroded. For instance, the landmark Internationale Handelsgesellschaft judgment aimed at the limitation of the review of constitutionality of acts of EU institutions by the German Federal Constructional Court. In response the German Constitutional Court ${ }^{75}$ as well as other constitutional courts of the Member States ${ }^{76}$ accepted the autonomy and primacy of EU law, yet, not unconditionally. They determined red lines preserving their own position and supremacy of national constitutions in court-to-court relation with the CJEU. ${ }^{77}$

Despite the fact that the CEE constitutional courts enter into the dialogue with the CJEU at a specific stage of development of EU law and in the situation when constitutional courts of the 'old' Union had already established their relations with the CJEU, they not only build up their own, constitutionally based approaches, but also actively participate in further developments at the EU level. When doing so,

72 26/62 NV Algemene Transport - en Expeditie Onderneming van Gend \& Loos (CJEU, 5 February 1963).

6/64 Costa v ENEL (CJEU, 15 July 1965).

11/70 Internationale Handelsgesellschaft GmbH (CJEU, 17 December 1970).

See: direct answer in Internationale Handesgesellschaft GmbH (Solange I) BvL 52/71 (German Federal Constitutional Court, 29 May 1974) and its development in Re Wünsche Handelsgesellchaft (Solange II) 2 BvR 197/83 (German Federal Constitutional Court, 22 October 1986); Brunner $v$ the European Union Treaty (German Federal Constitutional Court, 12 October 2013).

76 See: Frontini v Ministero delle Finanze 183/73 (Italian Constitutional Court, 27 December 1973); S.p.a. Granital v Amministrazione delle Finanze dello Stato 170 (Italian Constitutional Court, 8 June 1984); Administration des Douanes $v$ Societe 'Cafes Jacques Vebre' et SARL Wiegel et Cie (8 January 1971).

77 See more: M. Claes, The National Courts Mandate in the European Constitution (Hart Publishing 2006). 
they refer to experiences of other courts, however, within the framework of the national CEE constitutions.

Specific constitutional determinants have been affecting the position of CEE constitutional courts towards EU law. First, the strong sovereignty concerns must be taken into account as the challenge for constitutional courts to explain preservation of (newly recovered) independence with the process of the European integration. Secondly, the constitutional courts of new democracies had to build up their own position in the system. ${ }^{78}$ The two factors are clearly visible in the jurisprudence of all the courts subject to our analysis.

The Czech Constitutional Court in the first significant case concerning EU law, Sugar Quotas III, ${ }^{79}$ based its legal argumentation on distinction of EU Treaties form other international agreements on the basis of Art. 10a of the Czech Constitution authorising delegation of state powers on international organisation. The Court held that

[d]irect applicability in national law and applicational precedence of a regulation follows from Community law doctrine itself, as it has emerged from the case law of the ECJ. If membership in the EC brings with it a certain limitation on the powers of the national organs in favour of Community organs, one of the manifestations of such limitation must necessarily also be a restriction on Member States' freedom to determine the effect of Community law in their national legal orders. Art. 10a of the Constitution of the Czech Republic thus operates in both directions: it forms the normative basis for the transfer of powers and is simultaneously that provision of the Czech Constitution which opens up the national legal order to the operation of Community law, including rules relating to its effects within the legal order of the Czech Republic. The Constitutional Court is of the view that - as concerns the operation of Community law in the national law - such approach must be adopted as would not permanently fix doctrine as to the effects of Community law in the national legal order. A different approach would, after all, not correspond to the fact that the very doctrine of the effects that Community acts call forth in national law has gone through and is still undergoing a dynamic development. This conception also best ensures that which was already mentioned, that is, the conditionality of the transfer of certain powers.

The Czech Constitutional Court turned out to be the most open among discussed courts. The reasoning seems to reflect a pluralistic approach since the Court recognised not only the autonomy of EU law in terms of its adoption and validity but also found a legal basis for its applicability in the Czech Republic. The Constitutional Court found that since the accession of the Czech Republic to the EU,

78 Cf. W. Sadurski, "'Solange, chapter 3": Constitutional Courts in Central Europe - Democracy - European Union' (2006) 40 EUI Working Paper LAW.

79 Case Pl. ÚS 50/04 (Czech Constitutional Court, 8 March 2006). Cf. A. Albi, 'Supremacy of EC Law in new Member States. Bringing Parliaments into the Equation of "Cooperative Constitutionalism"' (2007) 3 European Constitutional Law Review, p. 25. 
a substantive change in the Czech constitutional order took place, and in consequence it is obliged to "interpret Czech constitutional law in the context of the principles of the Community [EU] law." ${ }^{80}$

The Court reviewed regulation on sugar quotas under national constitutional law, however, interpreted it in light of general principles of Union law as defined in the CJEU's case law. In subsequent decision Arrest Warrant ${ }^{81}$ it did so in extensive manner and interpreted the Czech Constitution in the light of the EU framework decision. The Court based its decision on Art. 1(2) of the Constitution of the Czech Republic in connection with the principle of sincere cooperation (now Art. 4(3) TEU, former Art. 10 TEEC) and formulated a constitutional principle, ${ }^{82}$ according to which

the domestic legal enactments, including the constitution, should be interpreted in conformity with the principles of European integration and cooperation between Community and Member State organs. If the Constitution, of which the Charter of Fundamental Rights and Basic Freedoms forms a part, can be interpreted in several manners, only certain of which lead to the attainment of an obligation which the Czech Republic undertook in connection with its membership in the EU, then an interpretation must be selected which supports carrying out of that obligation, and not an interpretation which precludes it. ${ }^{83}$

However, already in Sugar Quotas III, the Czech Constitutional Court expressed certain reservations in relation to the CJEU's doctrine of precedence of Union law over national constitutional law. The Court did so with reference to the case law of other European courts. It indicated decisions of the Italian Constitutional Court, ${ }^{84}$ the German Federal Constitutional Court, ${ }^{85}$ the Supreme Court of Ireland, ${ }^{86}$ the Supreme Court of Denmark ${ }^{87}$ and found that "all above

80 The Czech Constitutional Court found that "[a]lthough the Constitutional Court's referential framework has remained, even after 1 May 2004, the norms of the Czech Republic's constitutional order, the Constitutional Court cannot entirely overlook the impact of Community law on the formation, application, and interpretation of national law, all the more so in a field of law where the creation, operation, and aim of its provisions is immediately bound up with Community law. In other words, in this field the Constitutional Court interprets constitutional law taking into account the principles arising from Community law", para. VI.A.

81 European Arrest Warrant Pl. ÚS 66/04 (Czech Constitutional Court, 3 May 2006).

82 See: K. Wójtowicz, Constitutional Courts and European Union Law (Wydawnictwo Sejmowe 2014) 87.

83 Para. VIII.61.

84 Frontini v Ministero delle Finanze 183/73 (27 December 1973) and Fragd v Amministrazione delle Finanze dello Stato 232/1989 (Italian Constitutional Court, 21 April 1989).

85 Re Wünsche Handelsgesellchaft (Solange II) 2 BvR 197/83 (n. 76); Brunner v the European Union Treaty 2 BvR 2134 and 2159/92 (12 October 1993).

86 Society for the Protection of Unborn Children (Ireland) Ltd. v Grogan (Irish Supreme Court, 19 December 1989) and Attorney General v X (Irish Supreme Court, 5 March 1992).

87 Carlsen and Others v Rasmussen I-361/1997 (Danish Supreme Court, 6 April 1998). 
courts have never entirely acquiesced in the doctrine of the absolute precedence of Community law over the entirety of constitutional law but they retained a certain reservation to interpret principles such as the democratic law-based state and the protection of fundamental rights." ${ }^{88}$ The Court noticed the significance of judicial dialogue in that regard for the development of EU law. Elaborating its own position towards Union law, the Court based its findings on the concept of conditional conferral of powers under the Czech Constitution and held that this conditionality is manifested in the formal plane concerning the power attribute of state sovereignty itself, and the substantive component of the exercise of state powers. Consequently conferral has its limits and may persist as long as delegated powers are exercised in a manner that is compatible with the preservation of the foundations of state sovereignty of the Czech Republic, and in a manner which does not threaten the very essence of the substantive democratic state based on the rule of law. ${ }^{89}$

In subsequent judgements the Czech Constitutional Court became even more protective as regards its own position toward EU law. In Treaty of Lisbon I ${ }^{90}$ the Constitutional Court held that it possesses a power to review whether any act adopted by Union bodies exceeded the powers that the Czech Republic transferred to the EU pursuant to Art. 10a of the Constitution. However, the Constitutional Court assumed that such review would be possible in exceptional cases such as in particular, "abandoning the identity of values and exceeding of the scope of conferred competences."91 The Court further explained that

the supreme protector of Czech constitutionality, including against possible excesses by Union bodies or European law. [...] If European bodies interpreted or developed EU law in a manner that would jeopardize the foundations of materially understood constitutionality

88 Para. VI.A.

89 "Constitutional Court's view, this conferral of a part of its powers is naturally a conditional conferral, as the original bearer of sovereignty, as well as the powers flowing therefrom, still remains the Czech Republic, whose sovereignty is still founded upon Art. 1(1) of the Constitution of the Czech Republic. In the Constitutional Court's view, the conditional nature of the delegation of these powers is manifested on two planes: the formal and the substantive plane. The first of these planes concerns the power attributes of state sovereignty itself, the second plane concerns the substantive component of the exercise of state power. In other words, the delegation of a part of the powers of national organs may persist only so long as these powers are exercised in a manner that is compatible with the preservation of the foundations of state sovereignty of the Czech Republic, and in a manner which does not threaten the very essence of the substantive law-based state. In such determination the Constitutional Court is called upon to protect constitutionalism (Art. 83 of the Constitution of the Czech Republic). According to Art. 9(2) of the Constitution of the Czech Republic, the essential attributes of a democratic state governed by the rule of law, remain beyond the reach of the Constituent Assembly itself." Case Pl. ÚS 50/04 (n. 80), para. VI.A-3.

90 Lisbon Treaty I PI. ÚS 19/08 (Czech Constitutional Court, 26 November 2008) repeated in Lisbon Treaty II Pl. ÚS 29/09 (Czech Constitutional Court, 12 June 2010).

91 See: para. 120 Lisbon Treaty / Pl. ÚS 19/08. 
and the essential requirements of a democratic, law-based state that are, under the Constitution of the Czech Republic, seen as inviolable (Art. 9(2) of the Constitution) such legal acts could not be binding in the Czech Republic. ${ }^{92}$

This statement constitutes proclamation of constitutional identity clause conceived of as a red line demarcating the influence of the EU constitutional order on the Czech system. It was repeated and applied by the Czech Constitutional Court in the most controversial Slovak Pensions decision (discussed in point III.4), in which the Czech Constitutional Court adopted a dualistic rather than a pluralistic approach towards EU law.

The above described position of the Czech Constitutional Court shows, that the initial Euro-enthusiasm and openness to EU law has been replaced by a more preservative attitude, however, there are examples of judgments in which the Czech Constitutional Court in the course of examination of constitutionality of national implementing measures shaped constitutional standard following the doctrine established by the CJEU. ${ }^{93}$ Although the Czech Constitutional Court accepted exclusive jurisdiction of the CJEU as to the interpretation and the control of validity of Union law, ${ }^{94}$ it was quite sceptic towards its own classification as a court or tribunal in the meaning of Art. 267 TFEU. At the same time, the Czech Constitutional Court instructed other courts on the obligation to refer to the CJEU for interpretation of EU law ${ }^{95}$ and inspired by the German

92 See: para. 215 Lisbon Treaty / Pl. ÚS 19/08.

93 Case Pl. ÚS 36/05 (Czech Constitutional Court, 16 January 2007) the Constitutional Court inferred, on the basis of case law of the CJEU cases: C-229/00 Commission v Finland (12 June 2003), and C-424/99 Commission v Austria (27 November 2001), that interference with the right to fair process was also involved in the case on hand. "The way in which the European Court of Justice construes the principles corresponding to the fundamental rights and freedoms necessarily has repercussions when domestic law and its conformity with constitutionally protected rights are construed. Art. 1 of the Charter bestows special protection upon fundamental rights. If then that Court concluded that the decision on the inclusion of medicinal preparations into the list of medications covered by public health insurance funds results in an interference with the rights of their producers and distributors and, for that reason, it is necessary to see to it that the principles of fair process are consistently observed, then the Constitutional Court must take this line of argument into account when interpreting Art. 36(1) or (2) of the Charter", paras 40-41 of the judgment.

94 "The Constitutional Court held that it is not competent to assess the validity of Community law norms. Such questions fall within the exclusive competence of the European Court of Justice. In terms of Community law as it has been expounded by the European Court of Justice (hereinafter 'ECJ'), Community law norms enjoy application precedence over the legal order of Member States of the EC. According to the case law of the ECJ, where a matter is regulated solely by EU law, it takes precedence and cannot be contested by means of referential criteria laid down by national law, not even on the constitutional level."

95 See Czech Constitutional Court cases: III. ÚS 2738/07 (24 July 2008); I. ÚS 2553/07 (15 February 2010). 
Constitutional Court ${ }^{96}$ recognised failure of this obligation as a violation of the right to a fair trial. ${ }^{97}$ In the subsequent judgment, in order to strengthen the argumentation, the Court referred to the decision of the ECtHR in Ullens de Schooten et Rezabek $v$ Belgium $^{98}$ in which the Strasbourg Court found that Art. 6(1) ECHR places national courts under the obligation to provide rationale for any decision by which they refuse to submit a preliminary query. It means that in any case a refusal must be duly reasoned..$^{99}$ The last decision illustrates not only the extent of judicial dialogue on EU law in the Czech Republic but also the cross-fertilization of different legal systems, both European (international) and national, with regard to performance of obligations stemming from Treaties, on which the European Union is founded.

Whilst the Czech Constitutional Court's attitude towards EU law may be described as enthusiastic but cautious, the attitude of the Hungarian Constitutional Court towards EU law and the CJEU is not clear. The tactics of the Constitutional Court is to avoid confrontation. Shortly after the accession of Hungary to the EU the Constitutional Court examined the case concerning constitutionality of national legislation implementing EU regulations in the light of the principle of legal certainty. ${ }^{100}$ The Court refused to consider the case as based on Union law since it recognised that the EU regulations in question specified obligations for the new Member States rather than for their citizens, and that the provisions of the challenged national law did not qualify as a translation or publication of the regulations of the Union, as they implemented the aims of the regulations by using the means of Hungarian law. The recognition of the case as a purely internal one gave rise to the controversial outcome: the principle of legal certainty as a component of the democratic State prevailed over Hungary's obligations stemming from its participation in the European Union. ${ }^{101}$

In subsequent decisions the Hungarian Constitutional Court developed a doctrine, according to which EU treaties and their amending treaties are not international treaties from the perspective of jurisdiction of the Constitutional Court. ${ }^{102}$ The Constitutional Court found that "these treaties are primary sources of Com-

96 The Czech Constitutional Court referred to case BvR 2419/06 (German Federal Constitutional Court, 6 May 2008).

97 Case II. ÚS 1009/08 (Czech Constitutional Court, 8 January 2009).

98 Ullens de Schooten et Rezabek v Belgium, App. nos 3989/07 and 38353/07 (ECHR, 20 September 2011).

99 See: case II. US 1685/11 (Czech Constitutional Court, 30 November 2011), para. 18 quotation after Constitutional Court of the Czech Republic, National Report XVIth Congress of the Conference of European Constitutional Courts "Cooperation of Constitutional Courts in Europe - Current Situation and Perspectives" (25 September 2013) (English version of the judgment unavailable).

100 Case 17/2004 (V. 25.) AB IV. 1. (Hungarian Constitutional Court).

101 Cf. W. Sadurski (n. 79), p. 15.

102 See inter alia: 053/E/2005, 72/2006 (XII. 15.), 32/2008 (III. 12.), 61/2008 (IV. 29.), 76/2008 (V. 29.), 61/B/2005, 281/B/2007. 
munity law and the directives are secondary sources of Community law. They form part of the national legislation, since Hungary is the Member State of the EU" 103 and that "despite its international law origin the Community legal order is a sui generis legal order." ${ }^{104}$ Thus the Constitutional Court consequently recognises that Union law lays outside its jurisdiction. However, it recognised its own jurisdiction in the proceeding aiming at an a priori constitutional review of an international treaty. It means that in opinion of the Hungarian Constitutional Court amending treaties before the entry into force have in Hungary the status of a concluded international agreement. Once the treaties enter into force, they become a part of an autonomous legal order and, as such, a part of the Hungarian law. ${ }^{105}$ That's how the Hungarian Constitutional Court determined its own relation with the CJEU in Lisbon Treaty. ${ }^{106}$ The Court confirmed that "the authentic interpretation of the EU treaties and other EU-norms falls under the competence of the European Court of Justice." As a consequence, it recognised also its own obligation under Art. 267 TFEU to refer to the CJEU preliminary questions concerning EU law. However, in this particular case, with regard to the interpretation of current Art. 50 TEU, the Hungarian Court applied acte clair doctrine as formulated by the CJEU and found that the wording of the provision makes it clear that no state can be obliged to uphold its membership in the European Union, if it does not want to do so. This reasoning was used by the Constitutional Court as a confirmation of the fact that the membership in the EU does not influence the sovereignty of the state.

In Lisbon Treaty the Hungarian Constitutional Court, inspired by the German Federal Constitutional Court, also signalled an intention to perform an a priori control of constitutionality of amending European treaties only in exceptional cases and recognised own jurisdiction to conduct ultra vires review with respect to the protection of the limits of the powers conferred by Hungary upon the EU as well as constitutional identity. ${ }^{107}$ Such approach has been confirmed by the Court in the judgment concerning fiscal compact. ${ }^{108}$

The Polish Constitutional Court accepted supremacy of EU law and position of the CJEU already in Accession Treaty. ${ }^{109}$ The Court recognised autonomous

103 Case 1053/E/2005 (Hungarian Constitutional Court).

104 See: case 87/2008 (VI. 18.) AB (Hungarian Constitutional Court).

105 Case 32/2008 (III. 12.) (Hungarian Constitutional Court).

106 Decision 143/2010 (VII. 14.) AB (Hungarian Constitutional Court) on the constitutionality of the Act of promulgation of the Lisbon Treaty (Hungarian Constitutional Court, 12 July 2010). Press release: <http://www.mkab.hu/letoltesek/en_0143_2010.pdf> (access: between March 2014 and May 2016).

107 A.F. Tatham, "Keeping Faith" The Trials and Tribulations of the Hungarian Constitutional Court in Following its European Vocation', [in:] M. Bobek (ed.), Central European Judges Under the European Influence. The Transformative Power of the EU Revisited (Hart Publishing 2015), p. 349.

108 22/12 (V. 11.) AB.

109 Case K 18/04 (Polish Constitutional Court, 11 May 2006), para. III.2.2. 
Union legal order, as a part of international legal order based on Polish internal hierarchical principles, as an element of Polish legal order. According to the Court

\begin{abstract}
the concept and model of European law created a new situation, wherein, within each Member State, autonomous legal orders co-exist and are simultaneously operative. Their interaction may not be completely described by the traditional concepts of monism and dualism regarding the relationship between domestic law and international law. The existence of the relative autonomy of both, national and Community, legal orders in no way signifies an absence of interaction between them. ${ }^{110}$
\end{abstract}

The Court noticed that a potential possibility of a collision between regulations of Union law and the Constitution is not excluded. However, in most cases such collision may be resolved by a 'sympathetic to European law' interpretation of domestic law (including the Constitution). ${ }^{111}$ In the same case the Polish Constitutional Court established limits of the principle of interpretation of domestic law in a manner 'sympathetic to European law' and stressed that in no event may it lead to results contradicting the explicit wording of constitutional norms or being irreconcilable with the minimum guarantees included in the Constitution. In particular, the norms of the Constitution within the field of individual rights and freedoms indicate a minimum and unsurpassable threshold, which may not be lowered or questioned as a result of the introduction of Community provisions.

The above-described limitations were applied by the Court already in Arrest Warrant $I^{112}$ rendered few weeks before the Accession Treaty. The Constitutional Court noticed the obligation to assume an interpretation of national provisions consistent with Union law but decided that in case of obvious constitutional ban of extradition of Polish citizens, such interpretation is impossible. However, in the same case the Court used the possibility to maintain the legally binding force of unconstitutional provisions. The Court justified such decision by Art. 9 of the Constitution, according to which the Republic of Poland respects international law binding upon it. The Court found that this provision

is not only a grandiose declaration addressed to the international community, but also an obligation of state bodies, including the government, the parliament and the courts, to observe international law, which is binding for the Republic of Poland. Apart from introducing appropriate changes in the national legal order, the implementation of this obligation

110 See: para. III.6.2.

111 See also: case Kp 3/08 (Polish Constitutional Court, 18 February 2009) concerning preliminary ruling procedure in the third pillar of the EU, para. III.4.2, European Arrest Warrant II SK 26/08 (Polish Constitutional Court, 5 October 2010), para. III.2.4, and Lisbon Treaty K 32/09 (Polish Constitutional Court, 24 November 2010), para. III.3.2.

112 Case P 1/05 (Polish Constitutional Court, Court 27 April 2005). 
may require the public administration bodies to undertake specific actions within the scope of their assigned competencies. ${ }^{113}$

As a result, in the specific case addressed to the Constitutional Court and in pending and future cases before Polish courts, during the time of maintenance of legal force of an unconstitutional provision, the Constitutional Court granted priority to obligation to surrender stemming from the Framework Decision, before a constitutional ban of extradition of Polish nationals. ${ }^{114}$ This concession was granted, however, on the basis of the Constitution of Poland.

The Court noticed also that an irreconcilable inconsistency between a constitutional norm and a norm of Union law is possible. In such case a contradiction could not be eliminated through an interpretation, which would respect the mutual autonomy of European and national laws. According to Polish Constitutional Court

such a collision may in no event be resolved by assuming the supremacy of a Community norm over a constitutional norm. Furthermore, it may not lead to the situation whereby a constitutional norm loses its binding force and is substituted by a Community norm, nor may it lead to an application of the constitutional norm restricted to areas beyond the scope of Community law regulation. In such an event the Nation as the sovereign, or a State authority organ authorised by the Constitution to represent the Nation, would need to decide on: amending the Constitution; or causing modifications within Community provisions; or, ultimately, on Poland's withdrawal from the European Union. ${ }^{115}$

In Accession Treaty the Constitutional Court also answered the question on its relation with the CJEU. The Court did not support the applicants' submissions as regards the alleged inconsistency between the scope of competence of the CJEU, as defined by the Treaties and the principle of sovereignty of Poland, the supremacy of its Constitution in the Polish legal system and the specific legal status of the Constitutional Court. According to the Court, the CJEU is an authorised guard of the correct understanding of the Treaties, but it is not the only one. The interpretation of Union law delivered by the CJEU should be

113 See: para. III.5.5 of the judgment P $1 / 05$.

114 See more: K. Kowalik-Bańczyk, 'Should We Polish It Up? The Polish Constitutional Tribunal and the Idea of Supremacy of EU Law' (2005) 6 German Law Journal, p. 1355. According to M. Safjan, "in this judgement an ideal balance between on the one hand, the requirements stemming from the clear constitutional rule which forbade extradition of Polish citizen and, on the other hand, the requirements of the European framework decision on EAW, was struck" so in consequence two goals were achieved - preservation of supremacy of the Constitution and effectiveness of Union law. See: M. Safjan, 'Central \& Eastern European Constitutional Courts Facing New Challenges - Ten Years of Experience', [in:] M. Bobek (ed.), Central European Judges Under the European Influence. The Transformative Power of the EU Revisited (Hart Publishing 2015) 375.

115 See: para. III.6.3 of the judgment K 18/04. 
performed within the scope of competence and functions conferred thereupon by the Member States and should respect the principle of mutual loyalty of Union and Member States authorities. ${ }^{116}$ The above statement reflects a pluralistic expectation of mutual trust and understanding in the course of conducting a dialogue. The Polish Constitutional Court thus intentionally entered into a heterarchical cooperative relation with the CJEU. The above attitude was confirmed in the subsequent judgements ${ }^{117}$ and supplemented by the refusal to examine the conformity of Polish law with Union law. According to the Constitutional Court, in line with Art. 91 of the Constitution, it is for ordinary courts to decide on the inapplicability of a conflicting provision, if necessary, in cooperation with the CJEU in the preliminary ruling procedure. ${ }^{118}$ At the same time, the Constitutional Court recognized its own jurisdiction to examine constitutionality of Union 'normative acts', and, in particular, regulations. ${ }^{119}$ The Court clearly distinguished the control of constitutionality of any normative act applicable within the Polish legal system from the examination of validity of acts of EU institutions performed exclusively by the CJEU. It must be noticed that the reasoning of the Polish Court in crucial aspects of the case was based on the case law of the CJEU examining the conformity of the Regulation with the right of a fair trial. In part it was based on case law of the ECtHR, presuming axiological convergence between constitutional traditions of Member States of the European Union, the European Convention on Human Rights and the Charter of Fundamental Rights of the European Union. ${ }^{120}$ Importantly, after a careful analysis

116 K. Wójtowicz (n. 83), p. 90.

117 Polish Constitutional Court cases: Kp 3/08 (18 February 2009), K 32/09 (n. 112), SK 45/09 (November 2011) and K 33/12 (23 June 2013).

118 See: case P 37/05 (Polish Constitutional Court, 19 December 2006).

119 According to Art. 79(1) of the Polish Constitution, a constitutional complaint may be submitted to the Constitutional Court for it to determine "the conformity to the Constitution of a statute or another normative act", upon which basis a court or organ of public administration has made a final decision on a complainant's freedoms or rights or on his/her obligations specified in the Constitution. The Constitutional Court determined that regulations defined in Art. 188 TFEU as interpreted by the CJEU are 'another normative acts' within the meaning of Art. 79(1) of the Constitution. See: paras III.1.2-III.1.5.

120 The Constitutional Court stated that " $t$ t]he extensive catalogue of rights, freedoms and principles included in the Charter of Fundamental Rights stems, to a large extent, from the European Convention for the Protection of Human Rights and Fundamental Freedoms; the parties to the Convention also include the Republic of Poland. Pursuant to Art. 52(3) and (4) of the Charter of Fundamental Rights, in so far as this Charter contains rights which correspond to rights guaranteed by the Convention, the meaning and scope of those rights shall be the same as those laid down by the said Convention. This provision shall not prevent Union law providing more extensive protection. In so far as this Charter recognises fundamental rights as they result from the constitutional traditions common to the Member States, those rights shall be interpreted in harmony with those traditions. By contrast, on the basis of Art. 53 of the Charter, nothing in the Charter shall be interpreted as restricting or adversely affecting human rights and fundamental freedoms as recognised, in their respective fields of application, by Union law and international law and by international agreements to which 
of conformity of the regulation in question with the right to a fair trial as established in both Polish and Union legal orders ${ }^{121}$ the Court declared that since there is no doubt as to the conformity of the challenged Regulation with the EU primary law, taking into account the Foto-Frost doctrine, ${ }^{122}$ there was no need to refer a question to the CJEU for a preliminary ruling. ${ }^{123}$ This statement clearly indicates that in case of a doubt concerning the validity of a regulation the Court will refer the preliminary question to the CJEU in the future. It must be stressed that in contrast to the Czech or the German Constitutional Court, ${ }^{124}$ the Polish Constitutional Court does examine exclusively normative acts, and does not possess jurisdiction to control constitutionality of acts of application of law. It means that the Polish Constitutional Court is not entitled under Polish law to control constitutionality of the CJEU's judgements. ${ }^{125}$ The recognition of its own jurisdiction to control constitutionality of normative Union acts was the only one possibility for the Court to preserve its own position of the guardian of the Constitution in the field of EU law.

In Lisbon treaty the Polish Constitutional Court also formulated for the first time the concept of constitutional identity as the boundary for inclusion of international law and obligations streaming from it into constitutional order of the State. When doing so, the Court analysed decisions of the courts of other Member States concerning Lisbon Treaty, ${ }^{126}$ and noticed that although they varied due to different constitutional requirements of admissibility as regards challenging the Treaty, the constitutional courts share the position that the view that

the constitution is of fundamental significance as it reflects and guarantees the state's sovereignty at the present stage of European integration, and also that the constitutional judiciary plays a unique role as regards the protection of constitutional identity of the Member States, which at the same time determines the treaty identity of the European Union. ${ }^{127}$

the Union or all the Member States are party, including the Convention, and by the Member States' constitutions."

121 See: para. 6.4 of the judgment.

122 FotoFrost C-314/85 (CJEU, 22 October 1987).

123 Para. III.8.1.

124 The court invoked judgments of the Federal Constitutional Court of Germany to confirm exceptional nature of the control of constitutionality of acts of EU institutions.

125 It must be reminded that Solange doctrine concerns this kind of control of constitutionality see also Honeywell (Mangold) 2 BvR 2661/06 (German Federal Constitutional Court, 6 July 2010).

126 The Constitutional Court referred to cases: 143/2010 (Hungarian Constitutional Court); 2007-560 DC (French Constitutional Council, 20 December 2007); 2 BvE 2/08 (German Federal Constitutional Court, 30 June 2009); Pl. ÚS 19/08 (Czech Constitutional Court) (n. 91); 2008-35-01 (Latvian Constitutional Court, 7 April 2009), paras III.3.2-III.3.7.

127 The Court indicated that the position constitutes part of "European constitutional traditions", para. III.3.8. 
The Constitutional Court thus placed constitutional identity as an inherent element of a pluralistic constitutional constellation. Declaring that the common position described above constitutes "a vital part of European constitutional traditions", it suggested that constitutional identity should be treated as the main point of reference in relations between constitutional orders of the Member States and the constitutional order of the EU.

The Lithuanian Constitutional Court based its approach towards EU law on paragraph 2 of the Constitutional Act on Membership of the Republic of Lithuania in the European Union, according to which the norms of the European Union law shall be a constituent part of the legal system of the Republic of Lithuania. Whenever this provision concerns the founding Treaties of the European Union, the norms of the European Union law shall be applied directly. In an event of a collision of legal norms, European Union law shall have supremacy over the laws and other legal acts of the Republic of Lithuania. According to the Constitutional Court, the above provision constitutes a collision clause for all EU law. However, the Court made a reservation as to the relation between EU law and the Lithuanian law. ${ }^{128}$ The Constitutional Court stressed that "the constitution also consolidates the principle that in cases where a national legal act (save the Constitution itself, it goes without saying) establishes a legal regulation conflicting with the legal regulation set down in an international treaty, the international treaty should be applied." ${ }^{129}$ As the result, the Court recognised that "the jurisprudence of the CJEU as a source of construction of law is also important to construction and application of Lithuanian law." ${ }^{130}$

Potentially, an important element of cooperation between constitutional courts and the CJEU should be a preliminary reference procedure. ${ }^{131}$ Without entering into a deep discussion as to what constitutes this procedure and what is its role in judicial dialogue, it must be noted that the CEE constitutional courts, similarly to their counterparts form other Member States, avoid a direct dialogue with the CJEU, however, duly consider the case law of the CJEU. ${ }^{132}$ The Lithuanian Constitutional Court made the first preliminary

128 Case 17/02-24/02-06/03-22/04 (Lithuanian Constitutional Court, 14 March 2006).

129 Case 13/2010-140/2010 (Lithuanian Constitutional Court, 22 December 2011).

130 Lithuanian Constitutional Court cases: 30/03 (21 December 2006); 47/04 (4 December 2008) on the Compliance of paragraph 2 of Art. 15 of the Republic of Lithuania's Law on Electricity (wording of 1 July 2004) with the Constitution of the Republic of Lithuania, 33/06 (27 March 2009) on the Law on Trade Marks 7/04-8/04 (27 March 2009) on state secrets and official secrets, para. 15.

131 More about preliminary ruling procedure and judicial dialogue in CEE see: Czaplińska in this volume; T. de la Mare, C. Donnelly, 'Preliminary Rulings and EU Legal Integration: Evolution and Stasis', [in:] P. Craig, G. de Búrca (eds), The Evolution of EU Law (Oxford University Press 2011), p. 363.

132 Cf. G. Martinico, 'Judging in the Multilateral Legal Order: Exploring the Techniques of "Hidden Dialogue”' (2010) 21 King's Law Journal, p. 257. 
reference to the $\mathrm{CJEU}^{133}$ in 2007. The Czech and the Hungarian Constitutional Courts, although recognized themselves as 'courts' in the meaning of Art. 267 TFEU, constantly avoid to use the preliminary ruling procedure. ${ }^{134}$ The Polish Constitutional Court after a long time and a number of declarations ${ }^{135}$ finally decided to ask the Luxemburg Court to decide on validity of the Union directive in $2015 .{ }^{136}$

\subsubsection{The Dialogue with Other International Courts}

The judicial dialogue of the CEE constitutional courts with other international courts concerns mainly human rights protection and so involves references to decisions of the International Commission of Human Rights (rare and mainly supporting the adopted reasoning). ${ }^{137}$ Only exceptionally, the Czech Constitutional Court dissented from decisions of the Human Rights Committee. ${ }^{138}$ Decisions of other international courts are rarely invoked by constitutional courts, since, due to the scope of their jurisdiction, they do not apply often international law. The most experienced in this field are the Russian and the Ukrainian Constitutional Courts, however, although their decisions are broadly reasoned by international acts (both political and legal) there is no reference to the case law of international courts. ${ }^{139}$ The practice of the Polish Constitutional Court does

133 Case 47/04 (Lithuanian Constitutional Court, 8 May 2007) on the application to the Court of Justice of European Communities for a preliminary ruling.

134 See: case Pl. ÚS 154/08 (Czech Constitutional Court, 30 June 2008).

135 See especially: case SK 45/09 (n. 118). See: detailed analysis K. Kowalik-Bańczyk, 'Sending Smoke Signals to Luxembourg - the Polish Constitutional Tribunal in Dialogue with ECJ', [in:] M. Claes, M. de Visser, P. Popelier, C. Van de Heyning (eds), Constitutional Conversation in Europe. Actors, Topics and Procedures (Intersentia Publishing Ltd. 2012), p. 131.

136 Case K 61/13 (Polish Constitutional Court, 7 July 2015).

137 See i.a.: Pl. ÚS 37/04 (Czech Constitutional Court, 26 April 2006); 2/2014 (Lithuanian Constitutional Court, 4 November 2015); 10/2015 (Lithuanian Constitutional Court, 20 October 2015); P 29/09 (Polish Constitutional Court, 18 November 2010); 12-П/2016 (Russian constitutional Court, 19 April 2016).

138 See: Pl. ÚS 33/96 (Czech Constitutional Court, 4 June 1997); Pl. ÚS 45/97 (Czech Constitutional Court, 25 March 1998); Pl. ÚS 15/02 (Czech Constitutional Court, 21 January 2003) discussed by Wyrozumska.

139 See especially last cases concerning Crimea: 6-П/2014 (Russian Constitutional Court, 19 March 2014); 2-rp/2014 (Ukrainian Constitutional Court, 14 March 2014). What is significant there is obvious contradiction between findings of both courts resulting from different interpretation of the general principles of international law, namely right to self-determination of people and territorial integrity of state. In case of the Russian constitutional Court it must be noticed that after amendment of the Constitution of the Russian Federation also its interpretation of general international law was changed in regard to relation between above-mentioned principles of international law. See decision on unconstitutionality of proposed referendum on independence in Tatarstan of 1993 discussed by G. Danilenko, 'Implementation of International Law in Russia and Other CIS States' (1998) <http://www.nato.int/acad/fellow/96-98/danilenk.pdf> (access: between March 2014 and May 2016). 
not include judicial dialogue on international law with other international courts. The Czech Republic invocation of the International Court of Justice's Nottebohm ${ }^{140}$ to establish significance of international law in regard to recognition of citizenship $^{141}$ must be noticed. The practice of Lithuanian and Hungarian constitutional courts delivers interesting examples of judicial dialogue with international courts on international law.

The Hungarian Constitutional Court in the decision of $2003^{142}$ denied to accept the judgments of the ICJ as a source of constitutional obligation for Hungarian authorities. The case originated in the ICJ decision in Gabčikovo-Nagymaros. ${ }^{143}$ A member of the Hungarian Parliament submitted a constitutional complaint on the legislative omission through failure of implementation of the ICJ decision. The Constitutional Court held that the judgment of the ICJ cannot be considered as "a generally recognized principle of international law" or compared to incorporated international treaties. The Court held that

[e]ven though the proceedings of the International Court are based on the consent of the countries involved acknowledging the jurisdiction, as contained in an international treaty, the judgment is not a norm, not a contract, but the resolution of a specific dispute, even if some of its statements gain theoretical content or the value of a precedent. The International Court has no jurisdiction to annul an internal legal norm, to oblige the participating states to create law. The International Court cannot oblige the state to create law even if the state can only fulfil the obligation contained in the judgment by creating law. ${ }^{144}$

As a consequence, the Court declared the lack of jurisdiction to decide about an obligation of the Parliament or the Government to enact internal law or to conclude a treaty.

The position of the Hungarian Constitutional Court is coherently dualistic. We must observe at this point that the discussed approach to decisions of the ECtHR is based on recognition of the ECHR as an incorporated international agreement, which forms a part of the Hungarian legal order. The Constitutional Court recognises legally the binding force of the Convention but not of the Strasbourg Court decisions, which are solely to be taken into account in the process of interpretation of Hungarian law. The dualistic approach made it impossible to recognise decisions of international courts as sources of obligations if such an obligation is not envisaged in incorporated international treaty. However, it does not mean that the case law of international courts other than the ECtHR cannot be taken

140 Nottebohm Lichtenstein v Guatemala (ICJ, 6 April 1955).

141 Case Pl. ÚS 9/94 (Czech Constitutional Court, 13 September 1994) on the State power to grant citizenship under international law.

142 Case 988/E/2000 (Hungarian Constitutional Court, 7 October 2003).

143 Gabčikovo-Nagymaros Project, Hungary v Slovakia (ICJ, 25 September 1997).

144 See: para. 3.3. 
into account by Hungarian courts in the process of interpretation and application of international law. ${ }^{145}$

The most prominent example of judicial dialogue in application of international law is the decision of the Lithuanian Constitutional Court in Genocide. ${ }^{146}$ The case concerned the constitutionality of the Lithuanian Criminal Code, which retroactively provide for a criminal liability for genocide. The claimants argued that the Lithuanian law establishes a broader corpus delicti of genocide compared to that provided for in the international treaties in force to which Lithuania is a party. Furthermore, the claimants sustained that the retroactive effect of the national law is contrary to nullum crimen sine lege principle. The Court began its reasoning from Art. 135(1) of the Constitution and confirmed its former finding that in line with this provision the Republic of Lithuania

is obliged to follow the universally recognised principles and norms of international law; the said provision consolidates the constitutional principle of respect for international law, i.e. the principle of pacta sunt servanda, which means the imperative of fulfilling in good faith the obligations assumed by the Republic of Lithuania under international law, inter alia, international treaties.

The Court added that "the constitutional principle of pacta sunt servanda also means the imperative of fulfilling in good faith the international obligations arising from the universally recognised norms of international law (general international law) that prohibit international crimes." It means that, in contrast to the Hungarian Constitution, the Constitution of Lithuania incorporates whole international law including not only international treaties but also general principles of law and customary international law into the Lithuanian legal order.

In the next part of the judgement the Court recognized prohibition of genocide and other international crimes as jus cogens norms of international law. When doing so the Court carefully analysed international acts and judicial decisions. The Court referred to case law of the ICJ ${ }^{147}$ as well as to the decision of International Criminal Tribunal for Rwanda in Kayishema and Ruzindana. ${ }^{148}$ International case law was also broadly invoked to define the content of prohibition of genocide as an international customary law rule. The Court started its

145 Cf. N. Chronowski, E. Csatlós, 'Judicial Dialogue or National Monologue? The International Law and Hungarian Courts' (2013) 1 ELTE Law Journal, p. 26.

146 Case 31/2011-40/2011-42/2011-46/2011-9/2012-25/2012 (Lithuanian Constitutional Court, 18 March 2014).

147 The Court referred to Advisory Opinion on the Reservations to the Convention on Genocide (ICJ, 28 May 1951); Armed activities on the territory of the Congo, Democratic Republic of the Congo $v$ Rwanda (ICJ, 3 February 2006); Application of the Convention on the Prevention and Punishment of the Crime of Genocide, Bosnia and Herzegovina v Serbia and Montenegro (ICJ, 26 February 2007) and Jurisdictional Immunity of States Germany v Italy Greece intervening (3 February 2012).

148 ICTR-95-1-T Kayishema and Ruzindana (ICTR, 21 May 1999). 
analysis form the 1948 Geneva Convention on the Prevention and Punishment of the Crime of Genocide as reflection of customary law and then carefully analysed national law of several states, ${ }^{149}$ resolutions of the UN General Assembly, resolutions of the UN Security Council establishing international criminal courts and interpretation of genocide delivered by the ICJ in Application of the Convention against Genocide ${ }^{150}$ as well as the practice of international criminal courts ${ }^{151}$ and concluded that

under universally recognised norms of international law, states are under the obligation to adopt national legislation establishing liability for genocide. In the practice of the states concerned, the said obligation may also be understood as certain discretion, while taking account of a concrete historical, political, social, and cultural context, to establish, in their national law, a broader definition of the crime of genocide than that established under the universally recognised norms of international law, inter alia, as the possibility of including, within the respective national law, social and political groups in the definition of genocide. ${ }^{152}$

As the result, the Constitutional Court adopted a broad definition of genocide, shaped to cover crimes committed against Lithuanian residents recognized as political opponents during the period of the USSR totalitarian system. ${ }^{153}$ When

149 The Court held that "it should be noted that, when defining genocide, besides the groups protected under the Convention Against Genocide, the national law of more than twenty states additionally incorporates other groups in the respective lists of protected groups (inter alia, political groups and various social groups characterised on the basis of social status, age, sex, sexual orientation, etc.)", para. 3.3.

150 See: para. 3.3.4 of the judgment.

151 See: para. 3. The Constitutional Court invoked decisions of ICTY: IT-95-10 The Prosecutor v Jelisić (14 December 1999). IT-98-33 The Prosecutor v Krstić (2 August 2001); IT-95-16-T The Prosecutor v Kupreškić and Others (14 January 2000); IT-03-66-T The Prosecutor v Limaj and Others (November 2005); IT-02-60-T The Prosecutor v Blagojević and Jokić (17 January 2005) and ICTR cases: ICTR-95-1-T Kayishema and Ruzindana (21 May 1999); ICTR-96-4-T The Prosecutor v Akayesu (2 September 1998); ICTR-97-20 The Prosecutor v Semanza (15 May 2003); ICTR-95-54A-T The Prosecutor v Kamuhanda (22 January 2004).

152 See: para. 3.7 of the judgment.

153 "Thus, with consideration of such an international and historical context, inter alia, the aforesaid ideology of the totalitarian communist regime of the USSR upon which the extermination of entire groups of people was grounded, the scale of repressions of the USSR against residents of the Republic of Lithuania, which was a part of the targeted policy of the extermination of the basis of Lithuania's political nation and of the targeted policy of the treatment of Lithuanians as an 'unreliable' nation, the conclusion should be drawn that, during a certain period (in 1941, when mass deportations of Lithuanians to the Soviet Union began and non-judicial executions of detained persons were carried out, and in 1944-1953, when mass repressions were carried out during the guerrilla war against the occupation of the Republic of Lithuania), the crimes perpetrated by the Soviet occupation regime, in case of the proof of the existence of a special purpose aimed at destroying, in whole or in part, any national, ethnic, racial or religious group, might be assessed as genocide as defined according 
doing so, the Court defined the Geneva Convention term 'in part'154 as covering also a political or social group. Consequently the Court adjudicated positively on compatibility with the Lithuanian Constitution of Art. 99 of the Criminal Code, which stipulates that actions, aimed at physical destruction, in whole or in part, of persons belonging to any national, ethnic, racial, religious, and also social or political group.

When resolving the question of constitutionality of retroactive application of a wider notion of genocide enshrined in national law, the Court found that the norm of international law abolishing statutory limitations for prosecution and punishment of genocide concerns genocide as defined in the 1948 Geneva Convention. However, States may establish abolition of such limitations with reference to other crimes.

The Grand Chamber of the ECtHR considered these findings of the Constitutional Court a mere year later in Vasiliauskas v Lithuania. ${ }^{155}$ The ECtHR accepted that the domestic authorities have discretion to interpret the definition of genocide more broadly than that contained in 1948 Genocide Convention. However, such discretion does not permit domestic courts to convict persons accused under that broader definition retrospectively. According to the ECtHR, the current development of interpretation of term 'in part' used in the Geneva Convention was unforeseeable in 1953 when the applicant killed Lithuanian partisans ${ }^{156}$ and thus his conviction was contrary to nullum crimen sine lege principle contained in Art. 7 ECHR. It must be noted that the decision of the ECtHR was taken by 9 votes to 8 ,

to the universally recognised norms of international law (inter alia, according to the Convention Against Genocide)", para. 6.3.

154 "According to Article 1 of the Convention Against Genocide, genocide means any of the following acts committed with intent to destroy, in whole or in part, a national, ethnical, racial or religious group."

155 Vasiliauskas v Lithuania, App. no. 35343/05 (ECtHR, 20 October 2015). The case originated in conviction for genocide of member of Soviet security services and was involved in the killings of Lithuanian partisans under Lithuanian law. The main question to be resolved by the ECtHR was conformity of retroactive Lithuanian law with Art. 7 of the Convention.

156 The ECtHR found that "in 1953 there was no case law by any international tribunal to provide a judicial interpretation of the definition of genocide. [...] The Court [...] considers it reasonable to find that in 1953 it was foreseeable that the term 'in part' contained a requirement as to substantiality. [...] [H] owever, the Court is mindful of the subsequent development in the international case law on the crime of genocide. Half a century after the events for which the applicant was convicted, judicial guidance as to the interpretation of the phrase 'in part' emerged when cases concerning genocide were brought before the ICTY, ICTR and the ICJ. In particular [...], the intentional destruction of a 'distinct' part of the protected group could be considered as genocide of the entire protected group, provided that the 'distinct' part was substantial because of the very large number of its members. Furthermore, in addition to the numerical size of the targeted part, judicial interpretation confirmed that its 'prominence' within the protected group could also be a useful consideration. Be that as it may, this interpretation of the phrase 'in part' could not have been foreseen by the applicant at the relevant time", para. 176. 
which proves that international definition of genocide is still a subject of interpretative disagreements. Nevertheless, the decision of the Lithuanian Constitutional Court must be recognised as an important contribution to the development of international law.

The comparison of the Hungarian and Lithuanian approaches to international law also proves that constitutional openness, traditionally called as a monistic approach, and general incorporation of international law into domestic legal order creates favourable circumstances for judicial dialogue.

\subsubsection{The Dialogue with Foreign National Courts}

The judicial dialogue with foreign courts is deprived of any formal framework and is fully voluntary in nature and based on "a common substantive mission such as protection of human rights, at national, regional, or international level." ${ }^{157} \mathrm{Com}$ parative argument is thus based on presumption of universality of human rights. ${ }^{158}$ Decisions of foreign courts do not constitute binding legal sources, and for that reason they are not invoked by the Ukrainian and Russian Constitutional Courts. The lack of comparative arguments does not mean that foreign practice and comparative methodology is missing. In the Russian Constitutional Court there is a special unit for study and generalization of a foreign constitutional practice, which, whenever it is necessary and usually upon request by a judge repporteur, prepares surveys on decisions of foreign constitutional control bodies. ${ }^{159}$ It means that comparative analysis is present yet appears hidden in the practice of the Russian Constitutional Court.

The Czech, Hungarian, Lithuanian and Polish Constitutional Courts refer routinely to foreign national decisions. The reference to foreign courts takes place especially in 'problematic' cases, to draw inspiration for determination of democratic standards and proper balance between human rights and other interests. Constitutional courts most frequently refer to decisions issued by the Federal Constitutional Court of Germany which is explained in academia by historic and legal cultural affinities, linguistic ability and intellectual stimulus, constitution and constitutional jurisdictional formation in the post-Communist era and resulting influences on courts' judicial practice. ${ }^{160}$ However, references are also made to judgements of other national courts, including the CEE ones, especially in cases concerning common problems.

157 As suggested by Anne-Marie Slaughter "[c]ourts may well feel a particular common bond with one another in adjudicating human rights cases [...] because such cases engage a core judicial function in many countries around the world." A.-M. Slaughter (n. 35), p. 101.

158 Ibidem, p. 107.

159 See: Constitutional Court of the Russian Federation, National Report XVIth Congress (n. 72), p. 38.

160 A.F. Tatham, Central European Constitutional Courts in the Face of EU Membership: The Influence of the German Model in Hungary and Poland. The Influence of the German Model in Hungary and Poland (Martinus Nijhoff Publishers 2013), p. 5. 
The comparative reasoning may be used to change internal doctrine on particular legal institution like in the Czech example concerning the right to compensation for unlawful detention. ${ }^{161}$ Czech courts have for a long time rejected the possibility that the right covers also compensation for immaterial damage. The 2006 Constitutional Court's judgment analyses the decisions of selected national European courts (Germany, Austria, Greece, Denmark, the Netherlands) and the case law of the ECtHR relating to Art. 5(5) ECHR. It decided that:

\footnotetext{
irrespective of the manner in which the issues of damages is approached by the domestic legislator, case law of the ordinary courts and the Constitutional Court, and also the domestic doctrine of civil law, it is necessary, in the area of domestic application of the European Convention, to proceed from the notion of damage in the way it is conceptualised by other European constitutional and supreme courts, in whose case law is rooted also the case law of the European Court of Human Rights. ${ }^{162}$
}

The approach of the Czech Constitutional Court illustrates that the case law of foreign courts may be recognised as emanation of a universal or at least a European standard of protection of human rights. At the same time it illustrates interconnections between the mandatory dialogue (with the ECtHR) and a non-mandatory one with foreign courts. ${ }^{163}$

Constitutional dialogue with international and foreign jurisdictions, especially if it results in law-creating argument requires at least a minimal level of familiarity with an invoked legal system. Judges can optimally and reasonably use solution adopted by others, only if they are able to justify such practice. Otherwise, the position taken can be questioned and, as a result, prove inefficient before internal and external audience. Constitutional judges develop their knowledge on foreign law and practice not only by examination of legal sources but also during meetings with other judges and on the basis of academic contributions. ${ }^{164}$

Constitutional courts usually use comparative argumentation carefully considering both the circumstances of the case in hands and the level of approximation of referred legal systems with their own legal order. Therefore, they make reservations on limits of a comparative method. The Hungarian Constitutional Court in Election Procedure ${ }^{165}$ made a general statement with regard to a reference to foreign law suggested by the party to the proceedings. The Court found that:

161 M. Example after Bobek (n. 36) 156.

162 Case I. ÚS 85/04 (Czech Constitutional Court, 13 July 2006). Translation after M. Bobek, op. cit., p. 156.

163 Cf. ibidem, p. 156.

164 M. Rosenfeld, A. Sajó, 'Introduction', [in:] iidem (eds), Oxford Handbook of Comparative Constitutional Law (Oxford University Press 2012).

165 Case $1 / 2013$ (I. 7.) AB on the unconstitutionality of certain provisions of Act on Election Procedure (Constitutional Court, 4 January 2013). 
[ $\mathrm{t}$ ] he constitutionality of a specific legal institution in another country depends on the constitution of the given state, the fitting into the legal system, and on the historical and political background. Therefore, the Constitutional Court - though acknowledging that taking into account foreign experiences may help to evaluate certain regulatory solutions - does not consider the example of any foreign country in itself as a determining factor with regard to the review of constitutionality (compliance with the Fundamental Law). ${ }^{166}$

Similarly, the Polish Constitutional Court held that a comparative reasoning (including references to international law and practice) may be used, however, subject to various preconditions, especially if it aims at justification of dynamic interpretation of the Constitution. According to the Court:

there are particular circumstances in which one may resort to non-linguistic methods of legal interpretation $[\ldots]$. The role of those methods is subsidiary to linguistic and logical interpretation, however, even if by means of that method a text is found to be synonymous, its interpreter may sometimes 'go beyond' its determined meaning. However, a strong axiological substantiation is required which will mainly invoke constitutional values. It is also necessary to note that if the Court invokes a foreign internal law it is necessary to determine if the use of alien models is adequate to the interpretation of the Polish law. One should be particularly careful in „selecting” a legal system which is to be invoked. ${ }^{167}$

Interestingly, the Polish Constitutional Court treated in the same way the ECtHR case law and that of foreign courts as an emanation of a universal standard in the field of human rights protection which should be taken into account and justify dynamic interpretation of constitutional provisions.

The Czech Constitutional Court quite frequently refers to other constitutional courts and especially to the German Federal Constitutional Court, decisions of which were an undoubted source of inspiration in several fundamental cases concerning questions of Union law, discussed in other parts of this paper. ${ }^{168}$ Here one must notice the decision of 3 May $2012^{169}$ where the jurisprudence of the Polish Constitutional Court provided a strong persuasive argument in formulation of general principles regulating restrictions of judges' salaries. ${ }^{170}$ Also in the

166 Ibidem, III.3.4.

167 Case K 38/07 (Polish Constitutional Court, 3 July 2008), para. III.4.

168 See also i.a.: reference to the decision of the German Constitutional Court, the Italian Constitutional Court, the Austrian Constitutional Court, the Polish Constitutional Court, the Supreme Court of Spain, the Croatian Constitutional Court and the Supreme Court of the United States of America in Pl. ÚS 17/11 (Czech Constitutional Court, 15 May 2012) concerning photovoltaic power plants part VIII b paras 58-64 of the judgement; reference to the Polish Constitutional Court Pl. ÚS 33/11.

169 Case PI. ÚS. 3/11 (Czech Constitutional Court, 3 May 2012), para. VII.

170 "The following fundamental, general theses regarding the constitutionality of salary restrictions on judges arise from the case law of the Constitutional Court, as well as from comparison with the case law of European constitutional courts (see, in particular, decisions 
practice of the Hungarian Constitutional Court we can find referrals to decisions of foreign courts as sources of inspiration for interpretation of constitutional provisions. ${ }^{171}$

\subsection{The Main Fields of Judicial Dialogue}

\subsubsection{The Judicial Dialogue on Human Rights Protection}

As it was already mentioned, human rights protection constitutes the main field of judicial dialogue in the pluralistic legal order. On the one hand, the axiological similarity (nearly identity) of plural legal orders constitutes an essential element of ensuring coherence of the whole system. When applying national human rights provisions, constitutional courts refer to international courts' judgments not only on the basis of their legally binding force, but also to determine the European standard of protection. On the other hand, in difficult cases, in which there is a problem of proper balance between different rights and interests references to international and foreign courts' decisions strengthen the legal argumentation and deliver additional legitimization for a particular decision.

\subsubsection{Searching for a Common Standard of Protection - Consistent Interpretation}

Consistent interpretation is a well-established method used by national courts to avoid conflicts between domestic constitutional law and international and regional human rights law and to achieve conformity with European and international standards of human rights protection. Usually, Courts use judicial dialogue to bring an (evolving) standard of constitutional protection in line with a European standard stemming from the ECtHR but also the CJEU and foreign case law. In case of constitutional courts references to each other's decisions on human rights and judgments of international courts issues seem to be a highly effective tool of cross-fertilization. ${ }^{172}$

When judicial dialogue is relied on to achieve consistent interpretation of domestic and international human rights law in constitutional courts, the foreign or international courts' judgments do not usually form a part of a legal reasoning in determination of the content and the scope of an applicable norm. These courts use instead international and foreign material to support

of the Polish Constitutional Court: P 1/94 (8 November 1994); K 13/94 (14 March 1995); P 1/95 (11 September 1995); P 8/00 (4 October 2000); K 12/03 (18 February 2004)."

171 Case 1/2013 (I. 7.) AB (n. 166).

172 E. Benvenisti, 'Reclaiming Democracy: The Strategic Uses of Foreign and International Law by National Courts' (2008) 5 Tel Aviv University Law Faculty Papers 4. 
or supplement their primarily domestic law-based argument. ${ }^{173}$ In this regard, the judgment of the Polish Constitutional Court on the retirement age of men and women is a good example. The Constitutional Court considered exclusively the conformity between national provisions that set a different retirement age for men and women with Art. 32 (non-discrimination) and Art. 33 (equality of men and women) of the Polish Constitution. Regardless of such delimitation of the subject matter of the judgement, the Court devoted two separate parts in the judgment to the discussion of relevant $\mathrm{EU}$ and international standards of protection, including the case law of both the CJEU and the ECHR. In addition, the Constitutional Court noted explicitly, albeit in an obiter dictum, that the relevant provisions of domestic law were consistent with these European and international standards. ${ }^{174}$

Another example of a dialogue that resulted in bringing Polish law in line with the ECHR is a case concerning the reorganisation of intelligence services. ${ }^{175} \mathrm{In}$ this case, the Constitutional Court held that although it was unnecessary to refer to Art. 6 ECHR (since the right of fair trial was enshrined in Art. 45 of the Polish Constitution), it was necessary to refer to human rights treaties and the judicial practice of the ECtHR and other international human rights bodies to establish the constitutional standard of protection.

The Russian Constitutional Court considers case law of the ECtHR when interpreting constitutionally granted human rights and especially the right to a fair trial. ${ }^{176}$ For example, in the decision of 15 November 2011 the Constitutional Court referred to the decision of the ECtHR in Gorodnichev v Russia ${ }^{177}$ in examination of constitutionality of the decision on discontinuation of the criminal proceeding after death of an accused person challenged by his relatives. It is interesting that the referred decision concerning admissibility of application to the ECtHR (in the light of its Art. 6) after applicant's death. The decision of the ECtHR was not used as a decisive argument by the Russian Constitutional Court. It rather confirmed its own findings and showed due consideration to the ECtHR decisions in Russian cases. In the decision of 5 December $2011^{178}$

173 M. Wendel, 'Comparative Reasoning and the Making of a Common Constitutional Law - The Europe-Decisions of National Constitutional Courts in a Transnational Perspective' (2013) 25 Jean Monnet Working Paper, p. 9; J. Krzemińska, 'Courts as Comparatists: References to Foreign Law in the Case law of the Polish Constitutional Court' (2012) 5 Jean Monnet Working Paper, p. 49, <www.jeanmonnetprogram.org.> (access: between March 2014 and May 2016).

174 See: point III.3 under the heading "EU law provisions concerning equal retirement age of men and women" and III. 4 under the heading "International law provisions concerning equal retirement age of men and women" K 63/07 (Polish Constitutional Court, 15 July 2009).

175 Case K 51/07 (Polish Constitutional Court, 27 June 2008), para. III.4.2.

176 See inter alia Russian Constitutional Court cases: 29-П (30 November 2012); 5-П (17 March 2009); 6-П (25 April 2011); 16-П (14 July 2011).

177 Gorodnichev v Russia, App. no. 32275/03 (ECtHR, 15 November 2007).

178 Case 27-П/2011 (Russian Constitutional Court, 6 December 2011). 
concerning the constitutionality of the provision of the Russian Code of Criminal Procedure providing for home arrest, the Constitutional Court carefully analysed the case law of the ECtHR interpreting Art. 5 ECHR to establish a proper balance between the right to freedom and a public security interest. ${ }^{179}$ Furthermore, it attempted to determine the essence of the right to freedom in the context of distinction between depravation and limitation of liberty. ${ }^{180}$

However, there are also examples, in which case law of the ECtHR has been used as a persuasive authority to alter the scope of human rights protection granted under domestic law. In Maslov, handed down by the Russian Constitutional Court in $2000^{181}$ interpretation of domestic law in conformity with the jurisprudence of the ECtHR ${ }^{182}$ resulted in the alteration of the scope of rights of defendants in the Russian Code of Criminal Procedure. The Russian Constitutional Court stressed the obligation of law enforcement agencies to enable detained persons to access a defence counsel in the first hours of police questioning, even though neither the Russian Code on Criminal Procedure nor the Russian Constitution contained such an obligation at the time. ${ }^{183}$

The practice of the Russian Constitutional Court delivers also an interesting example of the use of the ECtHR case law to justify diminishing a constitutional standard of protection. ${ }^{184}$ It happened in the case concerning compensation for taking of property by the State under the 2000 Bankruptcy Protection Act. ${ }^{185}$ The Court decided that although the Constitution provides for expropriation by the State only by means of a judicial decision provided that "prior and equivalent compensation" is granted, the interpretation of the last condition as a right to a full compensation is not justified. As an argument, case law of the ECtHR was invoked. The Constitutional Court concluded that to achieve more social justice the amount of compensation must be fair, reasonable and proportionate to the public interest. So the Court instrumentally replaced literal meaning of the

179 Ibidem, para. 2.

180 Ibidem, para. 2.1. See also cases: 30-П (21 December 2011); 6-П/2015 (31 March 2015).

181 Case 11-ח (Russian Constitutional Court, 27 June 2000).

182 ECtHR judgments cited by the Russian Constitutional Court were Quaranta v Switzerland, App. no. 12744/87 (ECtHR, 24 May 1991) and Imbrioscia v Switzerland, App. no. 13972/88 (ECtHR, 24 November 1993).

183 For a detailed analysis of case law of the Constitutional Court of the Russian Federation see: National Report, Russian Federation, XVI Congress of the Conference of European Constitutional Courts, "Cooperation of Constitutional Courts in Europe - Current Situation and Perspectives”, Vienna, May 2014, <www.vfgh.gv.at/cms/vfgh-kongress/downloads/landesberichte/LB-Russie-EN.pdf> (access: between March 2014 and May 2016).

184 After A. Trochev, 'Russia's Constitutional Spirit: Judge-Made Principles in Theory and Practice', [in:] G.B. Smith, R. Sharlet (eds), Russia and its Constitution: Promise and Political Reality (Martinus Nijhoff Publishers 2008), p. 53.

185 See: case 8-П (16 May 2000). 
constitutional provision by interpretation "in conformity" with international obligations of the Russian Federation. ${ }^{186}$

Although, as it was pointed out before, for a long time the Ukrainian Constitutional Court was rather reluctant to make explicit references to case law of the ECtHR and other courts, in the latest practice the Court incorporates into its legal reasoning the analysis of the European standard of human rights protection. ${ }^{187}$ In the case of 22 April $2014^{188}$ the Court interpreted the provisions of Ukrainian Code of Civil Procedure deciding whether rulings of courts of first instance, which are not explicitly referred to in the Code are subject to a separate challenge in an appellate instance. When establishing the content and the scope of the right to appeal, the Court referred to the ECtHR judgements to support the extensive interpretation of domestic procedural law in the light of the right to appeal, under which everyone is guaranteed the right to appeal against decisions, actions or omissions of public authorities, local authorities, officers and employees. A court's refusal in admitting claims, complaints, issued in accordance with the procedural law is a violation of the right to a judicial protection, which, under Art. 64 of the Constitution cannot be restricted. The Court stressed that the realization of judicial proceedings on principles defined in the Constitution is the constitutional guarantee of everyone's right to judicial protection. One of these principles is to ensure the appeal and the cassation appeal against a court decision, except in cases established by law. In the judgment of 8 April $2015^{189}$ the Ukrainian Constitutional Court decided on unconstitutionality of the provisions of the Code of Administrative Proceedings of Ukraine, according to which a decision of a local general court in its capacity as an administrative court in cases concerning decisions, actions or omission of subjects of authority on bringing to administrative liability shall be final and may not be appealed, as it is contrary to the right to access to judgment. In its decision the Constitutional Court not only broadly analysed the case law of the ECtHR but also invoked the Charter of Fundamental Rights of the European Union as emanation of the European standard.

The dialogue with the CJEU may also bring domestic law in line with the European standard of human rights protection, especially, but not exclusively, in cases concerning measures implementing EU law in a domestic legal system. ${ }^{190}$ For example, the Lithuanian Constitutional Court in its decision of 15 May $2007^{191}$

\footnotetext{
186 A. Trochev (n. 185), p. 58.

187 See also examples presented by in this volume by T. Tsymbrivskyy.

188 Case 4-rp/2014 (Ukrainian Constitutional Court, 22 April 2014).

189 Case 3-rp/2015 (Ukrainian Constitutional Court, 8 April 2015).

190 Case: K 41/05 (Polish Constitutional Court, 2 June 2007); K 23/11 (n. 59).

191 Case 7/04-8/04 (n. 131).
} 
invoked the case law of both the $\mathrm{ECtHR}^{192}$ and the CJEU ${ }^{193}$ in order to interpret the notion of equality of any person before the court in the context of the right of the party to disclose information constituting a state secret. There the Court confirmed that

\begin{abstract}
the jurisprudence of the European Court of Human Rights as a source of construction of law is important to construction and application of Lithuanian law as well; the same can be said mutatis mutandis as regards the jurisprudence of the Court of Justice of the European Communities and the Court of the First Instance of the European Communities. ${ }^{194}$
\end{abstract}

Similarly, the Polish Constitutional Court in its judgment of 20 March $2006^{195}$ referred to the decision of the Court of the First Instance in Interporc $I I,{ }^{196}$ which concerned access to documents of European institutions as a proof of an existing standard.

The 2009 Polish Constitutional Court judgment ${ }^{197}$ may be considered as another example of a broad judicial dialogue on human rights protection with both the ECtHR and foreign courts. The Court was called upon to adjudicate a challenge to the constitutionality of the obligation to fasten seat belts in cars under the Polish Road Traffic Act. The applicant had been stopped by the police and fined for not fastening his seat belt. The applicant refused to pay the fine on the ground that the obligation in question was contrary to the right of privacy and violated his dignity. The Polish Constitutional Court referred to several cases of the ECtHR ${ }^{198}$ as well as of national courts ${ }^{199}$ to strengthen its argumentation concerning the acceptable scope of limitations to the right to privacy.

192 Edwards and Lewis $v$ the United Kingdom, App. nos 39647/98, 40461/98 (ECtHR, 27 October 2004).

193 Joined Cases T-110/03, T-150/03 and T-405/03 Jose Maria Sison v Council of the European Union (CJEU, 26 April 2005).

194 Ibidem, para. 15.

195 Case Sk 11/12 (Polish Constitutional Court, 23 October 2012). See also: case K 17/05 (Polish Constitutional Court, 20 March 2006).

196 T-92/98 Interporc v Commission (CJEU, 7 December 1999).

197 SK 48/05 (Polish Constitutional Court, 9 July 2009).

198 Among them to ECtHR cases: X v Belgium, App. no. 8707/79 (13 December 1979); Schmautzer v Austria, App. no. 15523/89 (10 May 1993); Viel v France, App. no. 41781/98 (14 December 1999).

199 For example: 1 BvR 1925/80 (German Federal Constitutional Court, 26 January 1982); 1 BvR 331/85 (German Federal Constitutional Court, 24 July 1986); 1 BvR 74/92 (German Federal Constitutional Court, 9 March 1992); Schmautzer B 821/88 (Austrian Constitutional Court, 27 February 1989); Society v Kohrig 62719-24, 498 N.E. 2d 1158 (US Illinois Supreme Courts, 1 October 1986); State v Hartog 88-383, 440 N.W. 2d 852 (US lowa Supreme Court, 17 May 1989); State v Eckblad 74109-3, 152 Wn. 2d 515, 98 3d 1184 (US Washington Supreme Court, 14 October 2004). 
Similarly, the Constitutional Court of Czech Republic in 2005 deciding about the scope of the right to judicial review ${ }^{200}$ referred to the decisions of the Slovak ${ }^{201}$ and Polish ${ }^{202}$ Constitutional Courts, laws of the Netherlands and Lithuania, and the jurisprudence of the ECtHR. ${ }^{203}$ It used these references to support its arguments that the right to an effective remedy was broader under the Czech Constitution than the protection granted by the ECHR.

The practice of the Hungarian Court provides also interesting examples of cases resolved in judicial dialogue with international and foreign courts. ${ }^{204}$ The most prominent one is the famous totalitarian symbols saga. ${ }^{205}$ In 2000 the Hungarian Constitutional Court did not find that the prohibition of using and wearing totalitarian symbols, including the 'five-point red star' unconstitutional. Mr. Vajnai who had been punished under this provision for wearing a five-point red star in public challenged this decision before the ECtHR. ${ }^{206}$ In its judgment Vajnai $v$ Hungary, the ECtHR concluded that the applicant's criminal conviction for simply having worn a red star had to be considered unnecessary, as it did not respond to a 'pressing social need'. Furthermore, the sanction against the applicant, although relatively light, came under criminal law, entailing serious consequences for the applicant. The sanction had therefore not been proportionate to the legitimate aim pursued. Accordingly, there had been a violation of Art. 10 ECHR. After the judgment of the ECtHR Mr. Vajnai had again been accused of wearing the red star in public. The Hungarian Supreme Court submitted a legal question to the Hungarian Constitutional Court. The Constitutional Court reversed its earlier judgment, and found the provision unconstitutional. In coming to this conclusion and establishing the proper level of protection, the Hungarian Con-

200 Case Pl. ÚS 11/04 (Czech Constitutional Court, 25 April 2005).

201 The Czech Constitutional Court referred to the judgment of the Slovak Constitutional Court of Pl. ÚS 15/03 (11 February 2004).

202 The Czech Constitutional Court referred to the judgment of the Polish Constitutional Court K 21/99 (10 May 2000).

203 Among them ECtHR cases: Incal v Turkey, App. no. 41/1997/825/1031 (9 June 1998); Sramek v Austria, App. no. 8790/79 (22 October 1989); Pellegrin v France, App. no. 28541/95 (8 December 1999).

204 See inter alia: 13/2000 (V. 12.) AB on the symbols of the State, 57/2001 (XII. 5.) AB on the right of reply, 22/2003 (IV. 28.) AB on euthanasia, 50/2003 (XI. 5.) AB on investigative committees, $6 / 2007$ (II. 27.) $A B$ on the questions 8 related to the prohibition of the publication of opinion poll results, 20/2007 (III. 29.) AB on the radio and TV broadcasting of the sessions of the Parliament, 53/2009 (V. 6.) AB on domestic violence and restraining order, para. III.3.4 and cases discussed by A. Wyrozumska 48/1998 (XI. 23.) AB; 21/B/2008, 154/2008 (XII. 15.) AB concerning the constitutionality of the Act of 2007 No. CLXXXIV on registered partnerships (Constitutional Court, 15 December 2008).

205 See: case 14/2000 (V. 12.) (Hungarian Constitutional Court, 9 May 2000). Discussed also in I. Skomerska-Muchowska, 'Judicial Dialogue on International Human Rights Law in Poland and Eastern Europe', [in:] A. Müller (ed.), Judicial Dialogue and Human Rights (Cambridge University Press forthcoming).

206 Vajnai v Hungary, App. no. 33629/06 (ECtHR, 8 July 2008). 
stitutional Court not only relied on the ECtHR's Vajnai judgment, but also referred to domestic law of Slovakia, Germany, Italy, Lithuania, Latvia, Romania, Poland and Ukraine, as well as to the decisions of foreign constitutional courts on the subject as an important persuasive argument based on similar social and political situation behind the legal problem at hands. ${ }^{207}$ The judgment of the ECtHR was referred to as a 'new circumstance' justifying reopening constitutional procedure concerning an already decided question of constitutionality and one of factors reflecting social changes.

Another interesting example of practice of the Hungarian Constitutional Court is the case concerning the right to reply to a press statement infringing his (subjective) rights. In this judgment the Court found unconstitutional the amendment to the Civil Code. The proposed provision permitted anyone to demand the publication of their reply in the press, if they felt that their rights had been infringed by a publication. The law envisaged sanctions, including court-imposed fines, against the media in the case of refusal to publish the reply. In the reasoning of the decision the Court suggested that the proposed regulation is inspired by American legal solutions. The Court thus compared European standard of protection of freedom of speech with the American one and found certain similarities as far as the principles are concerned, however, stressed that there are also significant differences as regards admissible restrictions to the freedom of expression and the freedom of the press as well as legal remedies for violation of the right in question. That is why, in the light of the Hungarian Constitution interpreted in conformity with the ECHR, the proposed regulation did not ensure a proper balance between conflicting rights and interests. Similarly, in other case concerning freedom of speech ${ }^{208}$ the Hungarian Court also referred not only to the European standard as established by the ECtHR but also to the practice of the US Supreme Court. ${ }^{209}$

In a sensitive case concerning euthanasia the Hungarian Constitutional Court rejected a constitutional claim concerning conformity of provisions obliging physicians to treat patients that they consider terminally ill with maximum care. The right to human dignity granted under Art. 54(1) of the Constitution was understood as containing the right to end one's life with dignity. The Constitutional Court supported its findings by a broad analysis of both case law and regulations in force in European states such as the Netherlands, Belgium, United Kingdom, Germany, as well as United States and Australia.. ${ }^{210}$

207 German Federal Constitutional Court cases: 1 BvR 680/86 (3 April 1990); 1 BvR 204/03 (23 March 2006); 1 BvR 150/03 (1 June 2006); 2 BvR 2202/08 (18 May 2009); and 74/1958 (Italian Constitutional Court, judgment, 20 December 1958) were referred in the judgment of 19 July 2011 of the Polish Constitutional Court.

208 Case 7/2014 (III. 7.) AB on the unconstitutionality and the annulment of the text "on the basis of acknowledgeable public interest."

209 Case 57/2001 (XII. 5.) AB, para. 2.2.

210 See: case 22/2003 (IV. 28.), paras 7-8 of the judgment. 
Similarly, judgment of Lithuanian Constitutional Court of $2011^{211}$ must be brought to the attention. ${ }^{212}$ The case concerned the concept of family adopted by the legislator who limited its scope solely to relations based on a formal marriage. The Lithuanian Constitutional Court carefully analysed case law of the ECtHR ${ }^{213}$ as well as national constitutional courts of Hungary, France and Germany ${ }^{214}$ and found that there is no commonly accepted definition of family. Nevertheless, the Court decided that although marriage is one of the bases of the constitutional notion of family on which family relations are founded, it does not mean that the Constitution does not protect families different than those founded on the basis of marriage. Such protection may be granted to, inter alia, the relationship of a man and a woman living together without concluding a marriage; the relationship based on the permanent bonds of emotional affection, reciprocal understanding, responsibility, respect, shared upbringing of children and similar features, as well as on the voluntary determination to take on certain rights and responsibilities, which form a basis for the constitutional notion of motherhood, fatherhood and childhood. ${ }^{215}$

\subsubsection{Shaping the Standard of Protection Through Judicial Dialogue - the Pilot Judgement Procedure and Beyond}

The ECtHR sometimes also confirms decisions of constitutional courts concerning incompatibility of national law or practice with human rights. This is true especially in cases of systemic violations when executive and legislature are unwilling or unable to ensure proper level of protection. The so-called Bug River claims' cases may serve as an example of such occurrences.

Following the World War II, the external borders of Poland were changed. And so Poland lost a major part of its territory eastwards from the Bug river. Inhabitants of that territory, according to the so-called 'Republican Agreements' ${ }^{216}$ have been repatriated westwards. The agreements provided for an obligation of evacuated landlords to leave substantial - quantitatively and qualitatively - parts of their property in the abandoned territories. The thus lost property was to be compensated by the Republic of Poland. Whilst most of the repatriates were compensated, a number of claims remained unsatisfied. In 2002 the Polish Ombudsman challenged before the Constitutional Court provisions of domestic laws restricting largely and practically impeding the possibility to compensate these losses as fore-

211 Case 21/2008 (Lithuanian Constitutional Court, 28 September 2011).

212 See also: 4/2012-13/2012 (Lithuanian Constitutional Court, 11 June 2015) on the transfer of a share of the personal income tax to municipal budgets.

213 See: para. III.2.

214 See: para. III.3.

215 See: para. III.13.

216 Agreements of 1944 concluded by the Polish Committee for National Liberation [PKWN] and governments of three Soviet republic: Belarusian, Ukrainian and Lithuanian, as well as in two treaties of 1945 and 1957 concluded between the governments of Poland and USSR. 
seen by the treaties. The Constitutional Court ${ }^{217}$ held that the Republican Agreements gave rise to legitimate expectations of the Polish citizens that issues of compensation would be regulated in domestic law. The compensatory mechanism created for persons deprived of their property as the result of territorial changes, led to the establishment of legitimate expectations of the interested parties, that the problem would be ultimately solved in the future in such a way, that interests of all subjects, entitled to thus created right, would be taken into consideration. The Constitutional Court held that right to credit provided for in Polish regulation is covered by the right to property. In this respect the unjustified limitations to realization of that right destroying the essence of the right in question made the practice illusory. It was not only contrary to Art. 64 of the Polish Constitution and Art. 1 of the Protocol 1 to the ECHR as interpreted by the ECtHR ${ }^{218}$ but also the rule of law (Art. 2 of the Constitution of Poland). ${ }^{219}$ The Court stressed that the unconstitutionality of challenged provisions "arises from the defective legal formulation of the provisions governing the question of compensation, which causes an inadmissible systemic dysfunction." According to the Court, the general property right as established by national law cannot be at the same time arbitrarily limited by the State in the way excluding substantial stocks of property from the compensation procedure, which de facto paralyses the possibility for beneficiaries to derive any economic advantage from these rights.

The judgement of the Constitutional Court had not been implemented neither by the executive, nor by the legislative. In 2004 Broniowski ${ }^{220}$ case was heard by the ECtHR, which broadly referred to and confirmed the findings of the Polish Constitutional Court as well as the related judgement of the Polish Supreme Court. ${ }^{221}$

217 Case K 33/02 (Polish Constitutional Court, 19 December 2002).

218 The Court held that " $\mathrm{t}]$ here can be no doubt that the right to credit belongs to the category of rights subject to protection under Art. 1 of Protocol No. 1 to the Convention for the Protection of Human Rights and Fundamental Freedoms."

219 According to the Constitutional Court " $[\mathrm{t}]$ he requirement of respect for the principle of maintaining citizens' confidence in the State and the law made by it, ensuing from the principle of the rule of law (Art. 2 of the Constitution), entails a prohibition on enacting laws that would create illusory legal institutions. This principle therefore requires that the obstacles which prevent [persons] from benefiting from the right to credit be eliminated from the legal system. From the point of view of the confidence principle, in the case of the right to credit it is the means of protecting this right that is subject to assessment, rather than its substance. The lack of opportunity to benefit from this right, within the framework set out by the legislature, shows that an illusory legal institution has been created, and thereby constitutes a violation of Art. 2 of the Constitution."

220 Broniowski v Poland, App. no. 31443/96 (ECtHR, 22 June 2004).

221 Case I CK 323/02 (Polish Supreme Court, 21 November 2003) in which the Supreme Court regarded the situation obtaining after the entry into force of the Constitutional Court's judgment, in particular the authorities' practices, to be unacceptable and contrary to the rule of law. 
The ECtHR fully accepted the Constitutional Court's conclusions concerning the lack of a legitimate aim pursued by Polish law and practice since they were based on its direct knowledge of national circumstances. ${ }^{22}$ The ECtHR also expressly repeated in the grounds for judgment arguments concerning a violation of the rule of law. The ECtHR noticed that the December 2003 Act on the exercise of the State Treasury's powers, the Law on commercialisation and privatisation of State enterprises and other statutes "constituted the culminating event of a series of actions and omissions of Polish executive and legislative." The Act deprived the claimant of any further compensation given that his family had previously received some kind of compensation. By imposing limitations on the exercise of the right to credit, and applying practices that made it unenforceable and unusable, these authorities also destroyed the very essence of his right. According to the ECtHR, the state of uncertainty in which Broniowski found himself as a result of the delays and obstructions over the years was in itself incompatible with Art. 1 Protocol No. 1 ECHR. The ECtHR then found that the violation had originated in a widespread and systemic problem, which had resulted from a malfunctioning of Polish legislation and administrative practice and which affected and remained capable of affecting a large number of persons. ${ }^{223}$ The Court concluded that the facts of the case showed the existence of a shortcoming, which affected a whole class of individuals. In view of this systemic problem, the Court declared that general measures were called for in the execution of the judgement. The ECtHR stated that these measures should include a scheme, which would offer redress to all persons affected, and not only to the applicant.

In Broniowski judgment the ECtHR used for the first time the pilot judgement mechanism. ${ }^{224}$ It held that Poland must take the general measures necessary to remove any obstacle to the implementation of the right to credit of persons affected, or provide equivalent redress, and ordered the State to secure the effective and expeditious realization of the title in respect of the remaining Bug River claimants through legislative and administrative measures and thus avoid repetitive violations in a lengthy series of comparable cases. It must be stressed that the finding of systemic violation was essentially based on the previous judgments of the Polish Constitutional Court. ${ }^{225}$ The ECtHR fully respected the role of the

222 See: Broniowski v Poland, para. 173.

223 Broniowski v Poland, para. 189.

224 See more, [in:] L. Wildhaber, 'Pilot Judgments in Cases of Structural or Systemic Problems on the National Level', [in:] R. Wolfrum, U. Deutsch (eds), The European Court of Human Rights Overwhelmed by Applications: The Problems and Possible Solutions (Springer-Verlag 2009), p. 69.

225 As noticed by Wildhaber "[t]he Broniowski judgment was particularly well-suited to the pilot-judgment kind of adjudicative approach; the Polish Constitutional Court and the Polish government were receptive to that approach; so in essence there was not much resistance", L. Wildhaber, (n. 226), p. 75. 
Constitutional Court as national guardian of human rights. Consequently, even if the pilot judgment moved towards a constitutional court-type jurisdiction of the ECtHR, since it prescribed general measures to be taken by national authorities, due regard to the previous judgement of the Constitutional Court obviously highlights subsidiary nature of the ECtHR itself.

A similar situation occurred in the Polish saga on restriction of landlords' rights to increase rents resulting in the Hutten-Czapska ECHR pilot judgement. ${ }^{226}$ The Polish Constitutional Court examined a number of times the legal situation of real-estate owners and decided on unconstitutionality of statutory law limiting their property rights read in the light of the ECHR. ${ }^{227}$ The judgments were not respected by the legislative power. The situation resulted in a number of applications to ECtHR. In Hutten-Czapska the Chamber of the Strasbourg Court again decided the case with due regard to findings of the Polish Constitutional Court and held that the government had failed to set an adequate balance between the interests of the landlords and that of the tenants so as to guarantee an equitable system of landlord rights and as result Poland violated Art. 1 of Protocol 1. The judgment of the ECtHR not only contained extraordinary long quotations of the Polish Constitutional Court's findings fully approved by the ECtHR, but also indicated that "it was incumbent on the Polish authorities to eliminate, or at least to remedy with the requisite promptness, the situation found to have been incompatible with the requirements of the applicant's fundamental right of property in line with the Constitutional Court's judgments." 228 The Grand Chamber repeated these arguments in the subsequent decision. ${ }^{229}$

Both Broniowski and Hutten-Czapska constitute examples of the cooperation between the two courts that can be even referred to as a 'judicial alliance ${ }^{\text {'230 }}$ for criticizing the domestic legal framework, and in bringing the legislative and executive branches of the State in compliance with the standards of rights protection

226 ECtHR cases: Hutten-Czapska v Poland, App. no. 35014/97 (22 February 2005); Hutten-Czapska v Poland, App. no. 35014/97 (19 June 2006); Hutten-Czapska v Poland, App. no. 35014/97 (28 April 2008). Detailed analysis Sadurski W., 'Partnering with Strasbourg: Constitutionalisation of the European Court of Human Rights, the Accession of Central and East European States to the Council of Europe and the Idea of Pilot Judgments' (2008) 08 Sydney Law School Legal Studies Research Paper, p. 15.

227 Case P 11/98 (Polish Constitutional Court, 12 January 2000). The Court referred to following decisions of the ECtHR, as to the existence of legitimate aim Spadea and Scalabrino $\mathrm{v}$ Italy, App. no. 12868/87 (28 September 1995), as to the definition of property right Sporrong and Lonnroth $v$ Sweden, App. nos 7151/75, 7152/75 (23 September 1982), as to the permissibility of limitation in rent system Scollo v Italy, App. no. 19133/91 (28 September 1995) and Velosa Baretto v Portugal, App. no. 18072/91 (21 November 1995).

228 Judgment of the Chamber of 22 February 2005, para. 187.

229 Judgment of the Grand Chamber of 19 June 2006, para. 223.

230 W. Sadurski (n. 228), p. 22. 
shared by both courts. ${ }^{231}$ The discussed cases prove that in some difficult cases it is necessary for the Constitutional Court and the ECtHR to act hand in hand to ensure a proper standard of protection of human rights. It must be stressed once again that judgments of the ECtHR were based on the findings of the Polish Constitutional Court and the dialogue with national judiciary. ${ }^{232}$ It is suggested by some scholars that in these cases the relation between the national constitutional court and the ECHR in the two situations of systemic violations took a very specific dimension. The constitutional court deals with a general constitutional dimension, while the ECtHR focuses on issues pertaining to a concrete case. However the general findings of the Constitutional Court were the main argument of the ECtHR justifying 'systemic' approach in individual case and prescription of general measures to be taken by the State.

Subsequently, the ECtHR continued thus established judicial dialogue in another pilot-judgment based Burdov saga. ${ }^{233}$ The applicant, a participant of emergency operations at the site of the Chernobyl nuclear plant disaster, repeatedly sued the competent State authorities, seeking payment of social benefits in connection with the resulting damage to his health. The Russian courts granted him the relevant payments but a number of their judgments remained unenforced. In 2000 the applicant lodged a first complaint with the ECtHR about the non-enforcement of domestic judicial decisions. In 2002 the Court found violations of Art. 6 ECHR and of Art. 1 of Protocol No. 1 to the Convention. ${ }^{234}$

It must be noted that in a similar case already in 2001 (so before the decision of the ECtHR in Burdov I) in the judgment of 25 January 2001, ${ }^{235}$ the Russian Constitutional Court, found the relevant provision of the Civil Code incompatible with the Constitution in so far as it provided for special conditions on State liability for damage caused by the administration of justice. ${ }^{236}$ The Court assumed that an individual should be able to obtain compensation for any damage incurred through a violation by a court of his or her right to a fair trial within the meaning of Art. 6 ECHR. The Constitutional Court called upon the Parliament to adopt appropriate legislative measures. Once the Burdov I judgment was issued, the Constitutional Court immediately referred to it and declared the law concerning social benefits for Chernobyl victims unconstitutional, as the system

231 W. Sadurski (n. 228), p. 23.

232 L. Wildhaber, 'Rethinking the European Court of Human Rigths', [in:] J. Christoffersen, M. Rask Madsen (eds), The European Court of Human Rights. Between Law and Politics (Oxford University Press 2011), p. 222.

233 Cf. P. Leach, H. Hardman, S. Stephenson, 'Can the European Court's Pilot Judgment Procedure Help Resolve Systemic Human Rights Violations? Burdov and the Failure to Implement Domestic Court Decisions in Russia' (2010) 2 Human Rights Law Review, p. 346.

234 See: Burdov v Russia, App. no. 59498/00 (ECtHR, 7 May 2002).

235 Case 1-П (n. 60).

236 The Court found, referring to relevant case law of the ECtHR, that an individual should be able to obtain compensation for any damage incurred through a violation by a court of his or her right to a fair trial within the meaning of Art. 6 of the Convention. 
thus created lacked clarity and predictability. ${ }^{237}$ Consequently, in 2004, the Russian Parliament amended the legislation and introduced a new system of indexation of allowances. However, the execution procedure reminded problematic. And so by force of a judgment of 14 July 2005, 238 the Constitutional Court considered certain provisions governing the special execution procedure to be incompatible with the Russian Constitution. Following the judgment, the Russian law was changed in that regard. In the meantime, Burdov obtained positive judicial decisions. Yet, there was a significant delay in their implementation so he had applied to the ECtHR for the second time.

In Burdov II, the ECtHR found it appropriate to apply the pilot-judgment procedure, given the recurrent and persistent nature of the underlying problems, the large number of people affected and the urgent need for a speedy and appropriate redress at the domestic level. ${ }^{239}$ In the statement of reasons the Strasbourg Court declared "considerable importance to the findings of the Russian Constitutional Court, which has invited Parliament since January 2001 to set up a procedure for compensation of damage arising, inter alia, from excessively lengthy proceedings. Of particular importance is the finding made by reference notably to Art. 6 of the Convention that such compensation should not be conditional on the establishment of fault." The above statement confirms that the pilot judgment procedure also in this case was based on prior findings of the national Constitutional Court.

In February 2010 the Russian Constitutional Court issued a decision concerning, inter alia, implementation of ECtHR decisions and the right to a fair trial. This judgement can be recognised as a response to Burdov II. ${ }^{240}$ The Court interpreted Art. 46 ECHR in the light of the case law of the ECtHR and when referring to Burdov II stressed that this provision imposes on the respondent State a legal obligation not only to effect payments to persons concerned as a just satisfaction awarded by the ECtHR, but also to take general and, if appropriate, individual measures

237 Case 11-П (Russian Constitutional Court, 19 June 2002). Cf. P.B. Maggs, O. Schwartz, W. Burnham, Law and Legal System of the Russian Federation (Juris Publishing 2015), p. 394.

238 Case 8-П (Russian Constitutional Court, 14 July 2005) after P. Leach, H. Hardman, S. Stephenson (n. 217), p. 349.

239 Burdov v Russia II, App. no. 33509/04 (ECtHR, 15 January 2009). The ECtHR noticed that these problems did not affect only Chernobyl victims, as in the present case, but also other large vulnerable groups of the Russian population: non-enforcement very frequently occurred in cases concerning the payment of pensions, child allowances and compensation for damage sustained during military service or for wrongful prosecution. Approximately 700 cases concerning similar facts were currently pending and in some instances could lead to the Court finding a second set of violations of the Convention in respect of the same applicants. It was a matter of grave concern that the violations found in the present judgment had occurred several years after its first judgment in the applicant's case, notwithstanding Russia's obligation under Art. 46 to adopt, under the supervision of the Committee of Ministers, the necessary remedial and preventive measures. The breaches found thus reflected a persistent structural dysfunction and a practice incompatible with the Convention.

240 Case 4-П (26 February 2010). 
to put an end to the violation in the domestic enforcement practice and to redress its effects as far as possible. Such measures are to be taken also in respect of other persons in a situation comparable to that of an applicant whose right the ECtHR found to be violated. Although it is for the respondent State to choose means by which the legal obligation based on Art. 46 of the ECHR will be discharged within a domestic legal system, such means must be compatible with the conclusions set out in a relevant judgment of the ECtHR. The Constitutional Court added, on the basis of the ECtHR case law, that save for cases where errors allegedly made by domestic courts in facts and in law could violate the rights and freedoms protected by the Convention, it is for the domestic authorities, namely judicial bodies, to decide on interpretation and application of the national legislation. ${ }^{241}$ The discussed decision fully confirmed findings of the ECtHR and called all state authorities for effective implementation of decision of ECtHR also in regard to a right to court. As the result of the described extensive dialogue between the Russian Constitutional Court and the ECtHR in March 2010 the Federal law on damages for violation of the right to fair trial within the reasonable time or the right to execution of a court ruling within reasonable time was adopted. ${ }^{242}$

It must be noticed that the pilot judgment mechanism, though born as a child of judicial dialogue, grew up on the basis of respect between the ECtHR

241 Para. 2 of the judgment.

242 In its Interim Resolution on the case, in December 2009, the Council of Europe Committee of Ministers noted "with satisfaction the Russian authorities' prompt and constructive response to the Court's pilot judgment and to the Committee of Ministers' Interim Resolution." Committee of Ministers, Interim Resolution CM/ResDH (2009) 158, Execution of the pilot judgement of the European Court of Human Rights in the case of Burdov No. 2 against the Russian Federation relative to the failure or serious delay in abiding by final domestic judicial decisions delivered against the state and its entities as well as the absence of an effective remedy, adopted on 3 December 2009. In two inadmissibility decision of 2010 the ECtHR held that the applicants were required to exhaust the new domestic remedy, whilst specifying that it might review its position in the future depending on the Russian courts' ability to establish consistent case law in line with the requirements of the European Convention on Human Rights (Nagovitsyn and Nalgiyev v Russia, App. nos 27451/09 and 60650/09 (ECtHR, 23 September 2010)). However in two subsequent judgments of 2012 the Court noted with regret that there was still no remedy available in Russia by which to complain of such delays where the judicial decisions in question imposed obligations in kind on the Russian State. That problem, in the Court's view, remained unresolved despite the 2010 Federal law following the Burdov II judgment. The Court therefore considered that an application before it continued to be the only means by which these applicants could assert their rights and obtain effective redress for the clear violations of their Convention rights (Ilyushkin and Others v Russia, App. nos 5734/08, 20420/07, 54342/08, 56997/08, 60129/08, 4561/09, 7738/09, $11273 / 09,11993 / 09,16960 / 09,20454 / 09,21964 / 09,26632 / 09,28914 / 09,31577 / 09,31614 / 09$, 31685/09, 32395/09, 35053/09, 36327/09, 38180/09, 45131/09, 48059/09, 52605/09, 56935/09, $58034 / 09,59761 / 09,1048 / 10$ et 1119/10 (ECtHR, 17 April 2012) and Kalinkin and Others $v$ Russia, App. nos 16967/10, 37115/08, 52141/09, 57394/09, 57400/09, 2437/10, 3102/10, 12850/10, $13683 / 10,19012 / 10,19401 / 10,20789 / 10,22933 / 10,25167 / 10,26583 / 10,26820 / 10,26884 / 10$, 28970/10, 29857/10, 49975/10 et 56205/10 (ECtHR, 17 April 2012). 
as the authoritative interpreter of the Convention and highest national courts as guardians of constitutionally granted rights. ${ }^{243}$ As it was emphasised, judicial dialogue has been a crucial element legitimising the law-creating attitude of the ECtHR. Once accepted it became an independent tool for resolution of systemic violations of the ECtHR or repetitive violation as determined in previous decisions of the ECtHR. ${ }^{244}$

Constitutional courts are supported by the ECtHR in enforcement of fundamental rights in other cases. In Biblical Centre of the Chuvash Republic v Russia ${ }^{245}$ the ECtHR had to decide about violation of Art. 9 ECHR by legislative and executive practice, which in the same time was contrary to decision of the Russian Constitutional Court. The Russian Court found application of dissolution, as a sanction against legal entities, imposed on formal grounds as unconstitutional. ${ }^{246}$ However, state organs did not follow the decision and applied dissolutions against religious schools without certification. The ECtHR held that such sanction against the applicant organisation was not necessary in a democratic society and thus contrary

243 In Varga and others v Hungary, App. nos 14097/12, 45135/12, 73712/12, 34001/13, 44055/13 and 64586/13 (ECtHR, 10 March 2015) the Court relied on several decisions of Kuria (the Supreme Court of Hungary) and the decision of the Constitutional Court (32/2014 (XI. 3.); similarly in Rutkowski v Poland, Rutkowski and Others v Poland, App. nos 72287/10, 13927/11 and 46187/11 (ECtHR, 7 July 2015) the ECtHR broadly referred to the case law of the Polish Supreme Court.

244 Yuriy Nikolayevich Ivanov v Ukraine, App. no. 40450/04 (ECtHR, 15 October 2009). The Court invoked as justification of application pilot judgment procedure extensive dialogue between the Ukrainian Government and the Committee of Ministers of the Council of Europe. Gazsó v Hungary, App. no. 48322/12 (ECtHR, 16 July 2015) and Ananyev and Others v Russia, App. nos 42525/07 and 60800/08 (ECtHR, 10 January 2012).

245 Biblical Centre of the Chuvash Republic v Russia, App. no. 33203/08 (ECtHR, 12 June 2014).

246 Case 14-ח (Russian Constitutional Court, 18 July 2003). The case before the Constitutional Court originated in the a judgment of the Commercial Court of the Yaroslavl Region, which rejected a prosecutor's application for a judicial order requiring the Islamic Religious Organisations of Yaroslavl Muslims to discontinue the unlicensed education of followers at a Sunday school (madrasa). The Federal Court pointed out that the education provided at the madrasa was not accompanied by a final evaluation and certification and therefore fell outside the scope of the Education Act. The Constitutional Court stated that "The fact that Art. 61(2) of the Civil Code does not contain a specific list of provisions whose breach may entail dissolution of a legal entity [...] does not imply that this sanction can be applied on formal grounds only, in the event of a repeated violation of regulations that are binding on legal entities. Taking into account the generally accepted principles of legal liability (including the presence of mens rea) and the criteria for restricting rights and freedoms enunciated in Art. 55(3) of the Constitution, which are binding both on lawmakers and law enforcement authorities, [Art. 61(2) of the Civil Code] presupposes that repeated violations of law, taken in their entirety, must be so gross as to allow the commercial court - having regard to all the circumstances of the case, including the nature of violations committed by the legal entity and their consequences - to decide on the dissolution of the legal entity as a measure necessary for the protection of rights and lawful interests of others." 
to Art. 9 ECHR interpreted in the light of its Art. 11. ${ }^{247}$ Another example of constructive dialogue between the Russian Constitutional Court and the ECtHR may be found in Khmel $v$ Russia. ${ }^{248}$

The Lithuanian Constitutional Court was also supported by the ECtHR in preservation of adequate level of protection of human rights in Lithuania. In $R a$ manauskas $v$ Lithuania $^{249}$ the ECtHR confirmed findings of the Lithuanian Court in case of 8 May 2000, ${ }^{250}$ in which the Court ruled that the Operational activities act was generally compatible with the Constitution however it also gives interpretation of the Act in conformity not only with the Lithuanian Constitution but also with the ECHR as interpreted by the ECtHR. ${ }^{251}$ Referring in particular to Teixeira de Castro $v$ Portugal the Lithuanian Court emphasised that a criminal conduct simulation model could not be used for the purpose of incitement or provocation to commit an offence that had not already been initiated. It further held that this investigative technique did not allow officials to incite the commission of an offence by a person who had abandoned plans to commit the offence. In spite of the decision Lithuanian authorities used incitement. The ECtHR in Ramanauskas $v$ Lithuania found that such practice contrary to the judgment of the Constitutional Court, violated Art. 6 of the Convention.

Examples of reinterpretation of the Constitution after the judgment of the ECHR are also present in the Czech practice. The Constitutional Court after the decision in Kohlhofer et Minarik $v$ Czech Republic ${ }^{252}$ pointed out that minority shareholders had to be protected within the light of Strasbourg case law. ${ }^{253}$ Similarly in regard

247 The ECtHR referred to the judgment of the Constitutional Court and held that "[t]he sanction of dissolution could be applied indiscriminately without regard to the gravity of the breach in question [...], a practice which the Constitutional Court found to be incompatible with the constitutional meaning of the relevant provisions as early as 2003. [...] In pronouncing the applicant organisation's dissolution, the Russian courts did not give heed to the case-law of the Constitutional Court or to the relevant Convention standards and their decision-making did not include an analysis of the impact of the applicant organisation's dissolution on the fundamental rights of Pentecostal believers. As it happened, their judgments put an end to the existence of a long-standing religious organisation and constituted a most severe form of interference, which cannot be regarded as proportionate to whatever legitimate aims were pursued", para. 61. See also similar approach of the ECtHR in Khmel v Russia, App. no. 20383/04 (ECtHR, 12 December 2013) referring to 86-O (Russian Constitutional Court, 14 July 1998).

248 Khmel v Russia, App. no. 20383/04 (ECtHR, 12 December 2013) referring to 86-O (Russian Constitutional Court, 14 July 1998).

249 Ramanauskas v Lithuania, App. no. 74420/01 (ECtHR, 5 February 2008).

250 12/99-27/99-29/99-1/2000-2/2000 (n. 52) on operational activity.

251 The Constitutional Court invoked Klass and Others v Germany, App. no. 5029/71 (ECtHR, 6 September 1978); Kopp v Switzerland, App. no. 23224/94 (ECtHR, 5 March 1998); Teixeira de Castro v Portugal, App. no. 44/1997/828/1034 (ECtHR, 9 June 1998).

252 Kohlhofer et Minarik v Czech Republic, App. nos 32921/03, 28464/04 and 5344/05 (ECtHR, 15 October 2009).

253 Case Pl. ÚS 14/10 (Czech Constitutional Court, 7 January 2011), para. 46. 
to decision of ECtHR in Husák $v$ Czech Republic ${ }^{254}$ concerning right of the accused to be heart in case of infringement of personal freedom before a court which makes a decision on the limitations of freedom, and this at any time such decision making takes place the Constitutional Court found that in principle, there is no reason for a child not to have the fundamental right to be heard directly before a court when a decision is being passed on restricting their personal freedom whilst an adult has such a right in the same circumstances. A relevant reason for denying the right of a child to be heard surely occurs when the child is not capable, with respect to the level of their development, of forming an opinion and evaluating the bearing of the measures relating to them. ${ }^{255}$

\subsubsection{The Dialogue on EU Law}

An important field of judicial dialogue in EEC is Union law. As it was already mentioned constitutional courts usually refer to foreign judgement to draw inspiration. Already in first decisions concerning EU law discussed in former part of the paper Polish and Czech Constitutional Courts invoked experience of their counterparts form 'old' Union. In these cases they did it briefly mainly to justify own position within pluralistic system as highest courts of national constitutional orders. ${ }^{256}$ Also the Hungarian Constitutional Court used case law of other courts in its decision Lisbon Treaty ${ }^{257}$ in similar way.

The conclusion of the Lisbon Treaty of 2007 gave rise new constitutional proceedings in which Polish and Czech Constitutional Courts, partly voluntary, partly provoked by the parties to the proceedings and the content of constitutional claims, made an in-depth comparative constitutional judicial analysis. ${ }^{258}$ The Czech Constitutional Court in Lisbon Treaty $I^{259}$ expressly declared that it took as inspiration case law of other constitutional courts and considered fundamental especially the decisions of the German Federal Constitutional Court in Solange II and the Maastricht ${ }^{260}$ However, in Lisbon Treaty II the Court was explicitly called by applicants to refer to the decision of the German Constitutional Court in order answer to the first question concerning definition of the "substantive limits to the transfer of powers" under eternity clause contained in the Czech Constitution. ${ }^{261}$

254 Husák v Czech Republic, App. no. 19970/04 (ECtHR, 4 December 2008).

255 Case II. ÚS 1945/08 (Czech Constitutional Court, 2 April 2009).

256 See: especially Polish Accession Treaty decision and Czech Sugar Quotas III decision.

257 143/2010 (VII. 14.) AB (n. 107).

258 See: broader discussion of Lisbon decisions of Member States Constitutional Courts in Lisbon Treaty cases by M. Wendel, 'Lisbon before the Courts: Comparative Perspective' (2011) 7 European Constitutional Law Review, p. 96.

259 Lisbon Treaty I Pl. ÚS 19/08 (n. 91).

260 See: paras $116-118$ and 139.

261 According to Art. 9(2) of the Czech constitution, the "substantive requisites of the democratic, law-abiding State may not be amended." According to Art. 1(1), the "Czech Republic is a sovereign, unitary and democratic, law-abiding State, based on respect for the rights and freedoms of man and citizen." See: M. Wendel (n. 174), p. 11. 
As noticed by the Court itself, the question was "evidently inspired by the decision of the German Constitutional Court."262 The Constitutional Court considered it impossible to construct this kind of catalogue of non-transferrable powers under the Czech Constitution. The Court confirmed its previous findings that establishment of such limits should be left primarily to the legislature, since it is an a priori political question. The Court also stressed that concepts of sovereignty and the rule of law should be defined on case-by-case basis. ${ }^{263}$ The Court also dissented from the decision of the German Constitutional Court with regard to the interpretation of the principle of democracy.

In Lisbon Treaty ${ }^{264}$ the Polish Constitutional Court carefully analysed decisions of other European Constructional Courts and concluded that "the jurisprudence the constitutional courts of the Member States share - as a vital part of European constitutional traditions - the view that the constitution is of fundamental significance as it reflects and guarantees the state's sovereignty at the present stage of European integration, and also that the constitutional judiciary plays a unique role as regards the protection of constitutional identity of the Member States, which at the same time determines the treaty identity of the European Union." The position of the Court is a pluralist one. It considered other members of the pluralist legal community to determine its own place in the whole system, on the one hand, and to confirm its own constitutional identity in relation to the CJEU and other courts. The subsequent part of the judgment stressed that legal solutions elaborated by other constitutional courts, even as distinguished as the German Federal Constitutional Court, cannot be considered suitable for the Polish constitutional framework. The Court was asked to determine the possible scope of transfer of powers and conditions of their execution under Art. 90 of the Polish Constitution. The Court held that it is neither its function to specify the content of the statute granting consent to ratification of an international agreement, as referred to in Art. 90 of the Constitution, nor to establish the rules of participation of the parliament and the government in implementation of the Treaty of Lisbon. ${ }^{265}$ The Court noticed that applicants' expectations in this regard were inspired by the judgement of the German Federal Constitutional Court, in which it decided not only on the consistency of the Treaty of Lisbon with the German Basic Law but also

262 See: Lisbon Treaty II (n. 91), para. 110.

263 The Court noticed that "[ $t$ ] his does not involve arbitrariness, but, on the contrary, restraint and judicial minimalism, which is perceived as a means of limiting the judicial power in favour of political processes, and which outweighs the requirement of absolute legal certainty [...]. The attempt to define the term 'sovereign, unitary and democratic state governed by the rule of law, founded on respect for the rights and freedoms of the man and of citizens' once and for all (as the petitioners, supported by the president, request) would, in contrast, be seen as an expression of judicial activism [...]."

264 Case K 32/09 (n. 112).

265 Para. III.2.6. 
on constitutionality of some provisions concerning the powers of the Parliament with regard to European matters. The Polish Constitutional Court noticed vital differences between the Polish and the German Constitution, when it comes to regulating the systemic foundations of European integration. According to the Court, in the Polish constitutional system it is for the drafters of the Polish Constitution and the legislator to resolve the problem of democratic legitimacy of the measures provided for in the Treaty, applied by the competent bodies of the Union. However, in the next part of the judgment the Court determined, on the basis of Preamble, Art. 2 (the rule of law) and Art. 8 (supremacy of the Constitution) of the Constitution, the catalogue of inalienable competences, the Court included the following: decisions specifying the fundamental principles of the Constitution and decisions concerning the rights of the individual which determine the identity of the state, including, in particular, the requirement of protection of human dignity and constitutional rights, the principle of statehood, the principle of democratic governance, the principle of a state ruled by law, the principle of social justice, the principle of subsidiarity, as well as the requirement of ensuring better implementation of constitutional values and the prohibition to confer the power to amend the Constitution and the competence to determine competences. ${ }^{266}$ The statement of the Court is very similar to that of the German Constitutional Court based on eternity clause defined in Art. 79(3) of the German Basic Law. ${ }^{267}$

The Polish Constitutional Court entered into a dialogue on interpretation of the founding treaties also in relation to the ratification of the European Council Decision amending Art. 136 TFEU. ${ }^{268}$ The Court supported its argumentation with the CJEU's decision in Pringle. ${ }^{269}$ It also analysed the judgement of the German Federal Constitutional Court ${ }^{270}$ to determine the nature of the Decision and found, following the reasoning of the two mentioned courts, that the Decision did not concern competences vested in the organs of state authority, and therefore it could not confer such competences upon an international organisation or an international authority.

Judicial dialogue is also present in cases concerning interpretation of obligations of States under secondary law of the European Union and covers not only referrals to the $\mathrm{CJEU}^{271}$ but also to other national courts. The best example of such dialogue is the case law relating to Directive 2006/24/EC of the European Parliament and of the Council of 15 March 2006 on the retention of data generat-

266 Para. III.2.1.

267 See: para. C.I.2 of the decision of the German Constitutional Court in Lisbon Treaty 2 BvE 2/08 (German Federal Constitutional Court, 30 June 2009).

268 Case K 33/12 (Polish Constitutional Court, 26 June 2013).

269 C-370/12 Pringle v Government of Ireland (CJEU, 27 November 2012).

270 Case 2 BvR 1390/12 (German Federal Constitutional Court, 12 September 2012).

271 See inter alia: 13/2013-34/2014 (Lithuanian Constitutional Court, 29 October 2015) on public interest services in the electricity sector, PI. ÚS 37/04 (n 138) on discrimination. 
ed or processed in connection with the provision of publicly available electronic communications services or of public communications networks and amending Directive 2002/58/EC ${ }^{272}$ (Data Retention Directive). ${ }^{273}$ It illustrates not only universality of rights protected under different constitutional orders, but also interactions between EU law and national law, which are in turn influenced by the ECHR. The case concerned compatibility of EU directive as well as national law both implementing the Directive and extending beyond this act with the right of respect of privacy and family life.

The Data Retention Directive as well as the national implementing measures evoked numerous doubts from the point of view of protection of the right to privacy. Consequently constitutional courts of Member States resolved number of cases concerning constitutionality of the system established by the Directive. ${ }^{274}$ The Directive constituted also the subject of judicial review by the CJEU in Digital Rights Ireland Ltd. within the preliminary ruling procedure instigated by the High Court (Ireland) and the Verfassungsgerichtshof (Austria). ${ }^{275}$ In the said judgment, the Court ruled that the Data Retention Directive 2006/24/EC was invalid as it violated Art. 7 (respect for private and family life) and Art. 8 (the protection of personal data) of the Charter of Fundamental Rights of the European Union. The CJEU found that the Data Retention Directive constituted a serious interference with the fundamental rights guaranteed in Articles 7 and 8 of the Charter, but it did not adversely affect the essence of those rights due to the fact that "Member States are to ensure that appropriate technical and organisational measures are adopted against accidental or unlawful destruction, accidental loss or alteration of the data." However, the vagueness of the Directive's text about Member States' obligation became one of the reasons for criticism. Moreover, the court acknowledged the danger of imprecise data treatment by electronic providers due to economic concerns, and found that the safeguards were insufficient. ${ }^{276}$ According to the Court,

272 OJ L 105, 13.04.2006, 54.

273 Data Retention Directive regulated obtaining and storing telecommunications data in EU Member States. It contained provisions concerning the obligations of the providers of publicly available electronic communications services or of public communications networks in regard to the retention of traffic and location data which are generated or processed by them, in order to ensure availability of such data for the purpose of the investigation, detection and prosecution of serious crime, as defined by each Member State in its national law. The Directive did not address issues related to the retention and disclosure of the content of communication via ICT networks. Pursuant to its Art. 6, data were to be retained for periods of not less than six months and not more than two years from the date of the communication.

274 Cf. T. Konstadinides, 'Destroying Democracy on the Ground of Defending It? The Data Retention Directive, the Surveillance State and Our Constitutional Ecosystem' (2011) 36 European Law Review, p. 722.

275 Joined cases C-293/12 and C-594/12 Digital Rights Ireland Ltd. (CJEU, 8 April 2014).

276 Para. 66 of the judgement. 
due to the significance of means of electronic communication in the modern world, data retained on the basis of the Directive in question provided national authorities with additional possibilities to shed light on serious offences. Thus, the fight against serious crime, in particular against organised crime and terrorism, constituted legitimate aim of limitation of fundamental rights. Yet, the restriction of rights imposed by the Directive were recognised by the CJEU as contrary to the proportionality requirements. It must be noticed that the CJEU based its findings concerning right to privacy on the jurisprudence of the ECtHR. ${ }^{277}$

It must be noted that before the CJEU's judgment in Digital Rights Ireland was issued, the Czech national provisions aiming at implementation of the directive were challenged before the Czech Constitutional Court. ${ }^{278}$ What is significant, due to a strict connection of provisions in question with EU law, applicants suggested asking a question to the CJEU about the potential invalidation of the Directive. The Constitutional Court found that although it is not competent to interpret acts of EU institutions, since it is an exclusive competence of the CJEU, it was not necessary to refer the question to the CJEU because national law in question went beyond the purpose of the Directive. ${ }^{279}$ However, it must be noticed that the same provisions of the Directive later annulled by the CJEU, such as obligation of retention of data with absolutely no differentiation, were also covered by the Constitutional Court review. In that regard the Czech Court argued that the Directive provided sufficient discretion to Member States to implement the measures and thus, this abstract review concerned a review of domestic and not Community legislation. Consequently, since there was no question of EU law being involved, preliminary reference was unnecessary. Furthermore, the Czech Court underlined its role as guardian of the Constitution and emphasised that national legislators had to comply with domestic constitutional principles when legislating, regardless of whether the essence of the measures originated from an external source. The position of the Czech Constitutional Court was inspired by the reasoning of the Federal Constitutional Court of Germany in similar case ${ }^{280}$ although not referred to in this part of the judgment.

The Czech Constitutional Court then proceeded with examination of the attributes of the contested legislation. Doing so the Court broadly referred to the case law of the ECtHR as well as to the decisions of other constitutional courts ${ }^{281}$ with

277 See paras: $35,47,54-55$ of the judgment.

278 Case Pl. ÚS 24/10 (Czech Constitutional Court, 22 March 2011).

279 See: para. 25 of the judgment.

280 Cases: 1 BvR 256/08, 1 BvR 263/08, 1 BvR 586/08 (German Federal Constitutional Court, judgment, 2 March 2010) Data Retention.

281 The Court referred to 1258 (Romanian Constitutional Court, 8 October 2009); (Supreme Court of Bulgaria, 11 December 2008); 65/2009, 78/2009, 82/2009 and 15/2010-22/2010 (Supreme Court of Cyprus, 1 February 2011). 
special attention devoted to the German Constitutional Court jurisprudence concerning the content and the scope of the right to privacy. ${ }^{282}$ The Court also referred to the decisions of the CJEU. ${ }^{283}$ In the conclusion the Constitutional Court found the national law on data retention disproportionate and thus, unconstitutional. The grounds of annulment were very similar to those indicated by the CJEU in Digital Rights Ireland Ltd.

It must be noted that in the last obiter dicta, the Czech Constitutional Court went back to the Data Retention Directive and called into question the validity of the Directive. It noted that there are serious doubts concerning data retention as an appropriate and effective measure as well as the necessity of such measures. In the light of these statements the refusal to refer the preliminary question to the CJEU is surprising. The only explanation of resistance of the Czech Court is preservation of its own role as a final arbiter in cases concerning domestic law and the position of the Constitution as the supreme law. The Court intended to avoid the situation in which it would be simply an executive body of a specific interpretation of both the directive and fundamental rights protected under EU law delivered by the CJEU. At the same time the Constitutional Court did not hesitate to support argumentation as to the interpretation of respective provision of the Constitution with references to foreign and international courts including the CJEU.

The above reasoning proves that court-to-court relation constitutes a very sensitive issue for the Czech Constitutional Court. On the one hand, as the European Arrest Warrant and other decisions showed, it can be recognised as Euro-friendly and open for interpretation of the Czech Constitution with the due consideration to European standards, on the other hand it is reluctant to use means of direct cooperation with the CJEU. ${ }^{284}$

The provisions of Polish law implementing the Data Retention Directive were challenged before the Constitutional Court after the decision of the CJEU. ${ }^{285}$ The Polish Constitutional Court in the statement of reasons firstly broadly analysed

282 Case BVerfGE 65 (German Federal Constitutional Court, 15 December 1983); BVerfGE 115 (German Federal Constitutional Court, 4 April 2006); 1 BvR 668/04 (German Federal Consitutional Court, 27 July 2005); 1 BvR 370/07, 1 BvR 595/07 (German Constitutional Court, 27 February 2008); 1 BvR 256/08, 1 BvR 263/08, 1 BvR 586/08 (n. 277).

283 The Czech Constitutional Court referred to joint cases C-92/09 and C-93/09 Volker und Markus Schecke GbR (CJEU, 9 November 2010) as indicating "[t]he necessity to provide, in a manner as stringent as possible, the guarantees and instruments for protecting the fundamental rights of individual when handling their personal data generated in course of electronic communications." See: para. 52.

284 P. Molek, 'The Czech Constitutional Court and the Court of Justice: Between Fascination and Securing Autonomy', [in:] M. Claes, M. de Visser, P. Popelier, C. Van de Heyning (eds), Constitutional Conversation in Europe. Actors, Topics and Procedures (Intersentia Publishing Ltd. 2012), p. 131.

285 Case K 23/11 (n. 59). 
the case law of the ECtHR with regard to Art. 8 ECHR (right to privacy). ${ }^{286} \mathrm{Sec}-$ ondly, the Court referred to the case law of the CJEU and other constitutional courts of the Member States. ${ }^{287}$ In regard to the above mentioned decision of the CJEU, the court noticed that although the CJEU's Digital Rights Ireland decision does not directly bind the Constitutional Tribunal in the procedure for the constitutional review of national provisions, "given the fact that there is a functional relation between the challenged provisions and the said Directive, and that the level of protection of privacy in the context of the storing and processing of personal data is - at least - not lower than the level guaranteed in Articles 7 and 8 of the Charter, the Constitutional Tribunal deems it useful to consider the decision of the CJEU a background for its own decision in the constitutional review of national provisions on granting access to telecommunications data to police forces and state security services." 288 The Constitutional Court also reminded that its competence to review the constitutionality of normative acts covers a situation where the allegation of unconstitutionality concerns a statute aimed at ensuring the effectiveness of EU law in the Polish legal order. ${ }^{289}$ In subsequent part of the judgment the Constitutional Court referred to decisions of other constitutional courts $^{290}$ to determine not only their way of understanding of right to privacy as guaranteed by European and national law and the scope of justified and necessary limitations in similar situations but also to find out the way of enforcement of the judgement of the CJEU.

It is obvious from the content of the judgment, that the previous judgment of the CJEU was decisive for the Polish Constitutional Court when evaluating the consistency of national provisions directly implementing the Data Retention Directive with human rights. ${ }^{291}$ What is significant is that the Court read the CJEU Digital Rights Ireland Ltd. decision in the light of case law of the ECtHR.

286 See: para. 2 of the judgement entitled "Selected jurisprudence of the European Court of Human Rights."

287 See: para. 3 of the judgement entitled "The retention of telecommunications data in the jurisprudence of the Court of Justice of the European Union and selected constitutional courts of EU Member States."

288 Para. 3.2.3 of the judgment.

289 Case P 1/05 (n. 113), para. III.2.4; Kp 8/09 (Polish Constitutional Court, 3 December 2009), para. III.4.

29013627 (Supreme Administrative Court of Bulgaria, 11 December 2008); 1258 (Romanian Constitutional Court 8 December 2009); 1 BvR 256/08 (n. 282); Pl. ÚS 24/10 (n. 281); Pl. ÚS 10/2014 (Slovakian Constitutional Court, 23 April 2014); G 47/2012, G 59/2012, G 62/2012, G 70/2012, G 71/2012 (Austrian Constitutional Court, 27 July 2014), 3 July 2014, the Slovenian Constitutional Court.

291 See: paras III.5.3, III.10.3 and III.10.4.3 of the judgement. In the literature the judgment is also recognised as the only one example of recognition of unconstitutionality of Polish law because of its inconsistency with EU law. Such a conclusion seems to be however kind of over interpretation of the Euro-friendly approach taken by the Constitutional Court. See: K. Kowalik-Bańczyk, 'Report on Poland', [in:] G. Martinico, O. Pollicino (eds), The National Treatment of the ECHR and EU Law. A Comparative Constitutional Perspective (2010), p. 329. 


\subsection{The Limits of Judicial Dialogue - from Sovereignty to Constitutional Identity}

As it was already mentioned, constitutional pluralism presupposed the existence of plural ultimate authority responsible for maintenance of coherence of the legal system and conformity of its norms with constitutional foundations. This task is performed by constitutional courts, on the one hand, and international courts (the ECtHR and the CJEU), on the other. From the perspective of institutional pluralism it is crucial to determine mutual legal relations between the highest courts. The common values, on which legal orders under consideration are based, minimalize the risk of conflict between them in the process of consistent and mutually sympathetic interpretation. However, the existence of such a conflict cannot be excluded and, as it was already mentioned, it is an inherent element of the pluralistic environment. The aim of this part of contribution is to explore limits of the judicial dialogue established in the practice of constitutional courts. We will look mainly at arguments used by courts in cases where they dissented from the decisions of international courts.

With regard to the CJEU, it must be remembered that the CEE constitutional courts reserved to themselves the power to control the protection of individuals' constitutionally granted rights, over the preservation of limits of powers conferred upon EU institutions and over protection of national constitutional identity. It is for each of the constitutional courts to determine the boundary conditions. The relation between national constitutional courts is determined by two main legal factors: the position of international and European law in a national legal order and the scope of jurisdiction of the constitutional court in question.

The Czech Slovak pensions saga constitutes a prominent example of difficult cooperation including tension between the Constitutional Court and the CJEU. It also shows that declared ultimate authority of the Constitutional Court may be successfully questioned though cooperation of other national courts with the CJEU in the preliminary ruling procedure. ${ }^{292}$ The dialogue between the Czech Constitutional Court and the CJEU was provoked by the conflict between the Czech Supreme Administrative Court and the Czech Constitutional Court.

292 See: detailed analysis in that regard: J. Komárek, 'Playing with Matches: The Czech Constitutional Court Declares a Judgment of the Court of Justice of the EU ultra Vires; Judgment of 31 January, PI. ÚS 5/12 Slovak Prensions XVII' (2012) 8 European Constitutional Law Review, p. 323; R. Král, 'Questioning the Recent Challenge of the Czech Constitutional Court to the ECJ' (2013) 19 European Public Law, p. 271; Z. Kühn, 'Ultra Vires Review and Demise of Constitutional Pluralism. The Czecho-Slovak Pensions Saga, and the Dangers of State Court's Defiance of EU Law' (2016) 1 Maastricht Journal, p. 183; G. Anagnostaras, 'Activation of the Ultra Vires Review: The Slovak Pensions Judgment of the Czech Constitutional Court' (2013) 14 German Law Journal, p. 959; R. Zbíral, 'A Legal Revolution or Negligible Episode? Court of Justice Decision Proclaimed Ultra Vires' (2012) 49 Common Market Law Review, p. 1457. 
The case originated in the specific historical legal circumstances connected with the dissolution of Czechoslovakia and the conclusion between the Czech Republic and the Slovak Republic of an international agreement aimed at coordinating matters relating to social security benefits. The criterion chosen for determining the applicable scheme and the authority with competence to grant such benefits was that of the State of residence of the employer at the time of dissolution of Czechoslovakia. Since the adopted solution resulted in differentiation of economic situation of Czech citizens based on former employer's residence, the Constitutional Court, on the basis of Art. 30 of the Czech Charter of Fundamental Rights, decided on special subsidiary payment to Czech citizens, residing in the Czech Republic conceived of as an additional benefit to pensions provided for in Art. 20 of the Czech-Slovak Agreement of 1992. ${ }^{293}$ The Czech Administrative Court disagreed with the law-creating decision and refused to apply Czech law as contrary to the Council Regulation 1408/71 on the application of social security schemes to employed persons moving within the Union as interpreted by the CJEU. ${ }^{294}$ The decision of the Supreme Administrative Court was challenged subsequently before the Constitutional Court. There existed a clear necessity to interpret EU law after the accession of the Czech Republic and Slovakia to the EU as the Czech-Slovak Agreement became a part of EU law. ${ }^{295}$ It seemed that the Constitutional Court had thus an excellent opportunity to make a reference to the CJEU and to submit constitutional arguments to support its own position. Instead, the Czech Court based the final decision on its own interpretation of the Regulation. In consequence it found Union law inapplicable to the case for temporal reasons and on this ground quashed the decision of the Supreme Administrative Court. ${ }^{296}$

In such a situation the request for a preliminary ruling concerning the conformity of the supplementary payment with EU law was submitted to the CJEU by the Supreme Administrative Court. ${ }^{297}$ Since the reference resulted in suspension of other similar proceedings until the judgment of Luxembourg Court was issued, the Constitutional Court was granted another opportunity to change its position

293 The Czech Constitutional Court in the first Slovak Pensions case held that Art. 20 of the Czech-Slovak Agreement was contrary to constitutional right to an adequate material security in old age. It found that it is necessary to bring the amount of old age benefits of Czech citizens granted under Art. 20 of the Agreement into line with the amount due to other pensioners residing in the Czech Republic, as required by Czech domestic law, including Pl. II. ÚS 405/02 (Czech Constitutional Court, 6 March 2003). In the subsequent judgment the Court found that beneficiaries of the special increment are solely Czech citizens residing in the Czech Republic. Pl. II. ÚS 252/04 (Czech Constitutional Court, 25 January 2005).

294 Case 3 Ads 2/2003-112 (Czech Supreme Administrative Court, 26 October 2005).

295 The agreement because it was listed in the third Annex of the Regulation 1408/71 and not listed in the annex as still applicable but interpreted in accordance with the general principles of EU law.

296 Case Pl. ÚS 4/06 (Constitutional Court, 20 March 2007).

297 Case 3 Ads 130/2008 (Czech Supreme Administrative Court, 23 September 2009). 
since the decision on suspension was challenged before it. The Constitutional Court, however, not only sustained its former findings as to the scope of application of the Regulation, but also recognised that in situation when inapplicability of EU law was manifest, the referral to the CJEU was inadmissible and contrary to the Constitution. ${ }^{298}$

The Supreme Administrative Court referred to the CJEU two questions: the first one concerning the conformity of conferral of a supplementary payment under the judgment of the Constitutional Court with the Regulation, the second concerning conformity of requirement of citizenship and residency with the principle of non-discrimination as established in the Regulation. What is significant, in the conduct of the procedure before the CJEU, the Czech government argued against the judgment of the Czech Constitutional Court, which means that national constitutional interests connected with history of the State invoked by the Constitutional Court were not presented to the CJEU. In reaction, the Constitutional Court decided to submit its own statement to the CJEU to provide supplementary information and arguments for the proceeding, however the CJEU refused to accept it.

In C-399/09 Landtová, ${ }^{299}$ the CJEU had no doubts that the Regulation is applicable in the case and decided that the provisions of EU law do not preclude a national rule, such as that at issue in the main proceedings, which provides for payment of a supplement to old age benefit where the amount of that benefit, granted pursuant to the Czech-Slovak Agreement, is lower than that which would have been received if the retirement pension had been calculated in accordance with the legal rules of the Czech Republic. However, when answering the second question, the CJEU held that supplementary payment granted solely to Czech nationals residing in the territory of the Czech Republic is inconsistent with EU law as discriminatory measure, based on precondition of nationality, differentiating between Czech nationals and nationals of other Member States. The Court also explained that EU law does not require depravation of such payment to an individual who satisfies the requirements. ${ }^{300}$

After the judgment of the CJEU the Supreme Administrative Court issued a rather provocative decision where it stated that since the judgment of the Constitutional Court was not only contrary to EU law but also violated the duty to refer a preliminary question to the CJEU, the Supreme Administrative Court is not bound by the effective judgement. Paradoxically, the Administrative

298 Case III. ÚS 1012/10 (Czech Constitutional Court, 12 August 2010).

299 C-399/09 Marie Landtová v Česká správa socialního zabezpečení (CJEU, 22 June 2011).

300 The CJEU held: "EU law does not, provided that the general principles of EU law are respected, preclude measures to re-establish equal treatment by reducing the advantages of the persons previously favoured" and added, that "before such measures are adopted, there is no provision of EU law which requires that a category of persons who already benefit from supplementary social protection, such as that at issue in the main proceedings, should be deprived of it", ibidem, paras 53-54. 
Court based its findings on previous decisions of the Constitutional Court, in which the Constitutional Court quashed decisions of the Supreme Administrative Court because of the breach of the constitutional right to lawful judge. Moreover, the Supreme Administrative Court pointed out that although it did not question the position of the Constitutional Court as the guardian of the Constitution, the possibility of recognition of EU decisions as unconstitutional (according to the case law of the Constitutional Court ${ }^{301}$ ) is exceptional and possible only if the relevant provisions of EU law violate the material core of the Constitution.

As the result, the Czech Constitutional Court for the first time in the history of the EU recognised the ruling of the CJUE to be ultra vires. ${ }^{302}$ The Court held that the "[f]ailure to distinguish the legal relationships arising from the dissolution of a state with a uniform social security system from the legal relationships arising for social security from the free movement of persons in the European Communities, or the European Union, is a failure to respect European history, it is comparing things that are not comparable." In consequence, according to the Constitutional Court "in that case there were excesses on the part of a European Union body, that a situation occurred in which an act by a European body exceeded the powers that the Czech Republic transferred to the European Union under Art. 10a of the Constitution; this exceeded the scope of the transferred powers, and was ultra vires."

The position of the Constitutional Court seems to be surprising in the light of previous decisions concerning Union law. In the discussed case the Constitutional Court consistently considered it as a purely internal one since from a national perspective the main problem was not the conformity of the special payment with EU law but a law-creating activity of the Constitutional Court. ${ }^{303}$ It must be repeated that the decision of the Constitutional Court was the sole ground of the supplementary benefit. The Constitutional Court missed the question of Union law in the first decision and, to defend its own legal construct, deemed EU law inapplicable. Such false assumption seems to have been the main reason for the disagreement. The whole argumentation of the Court is highly emotional and the application of ultra vires concept remains doubtful. The position of the Constitutional Court is based on a subjective interpretation of historical facts. At the same time, not only other Czech courts challenged the position of the Constitutional Court but also the Government and the Parliament $^{304}$ disagreed. This fact clearly indicates the internal conflict between state authorities and judicial bodies.

301 Case Pl. ÚS 50/04 (Czech Constitutional Court, 8 March 2006) and Pl. ÚS 19/08 (n. 91).

302 Slovak Pensions Pl. ÚS 5/12 (Czech Constitutional Court, 31 January 2012).

303 Cf. J. Komàrek (n. 293), p. 325.

304 Shortly of the judgment of the CJEU the Parliament adopted an act, which prospectively excluded the possibility of paying the special supplement to everyone with a specific reference to the CJEU's ruling. 
The Constitutional Court accused the CJEU of a lack of good will and cooperation and pointed to "deficiencies concerning the safeguards of a fair trial in the proceedings" before the CJEU. For the Constitutional Court it was obvious that the CJEU had a legal possibility to accept its letter. ${ }^{305}$ However, such possibility is not expressly indicated in the Statute of the CJEU. In opposition to the procedural position of the Commission, and State governments and other institutions involved in the procedure before national court, interventions of a third party is not regulated by the Statute of the CJEU. ${ }^{306}$ It must be also stressed that the function of the preliminary ruling procedure is to interpret EU law in circumstances of a particular case to support the national court in application of that law on the one hand and ensure its uniform application in the whole Union on the other. That's why the CJEU is bound by findings of referring court as to the applicable national law. ${ }^{307}$ The CJEU does not resolve disputes between state authorities in this procedure. If it had accepted the letter of the Constitutional Court, the CJEU would have put itself in the position of an arbiter between the Supreme Administrative Court, the Czech Government and the Constitutional Court. Thanks to the fact that it rejected the letter of the Constitutional Court, the CJEU simply performed its function and interpreted the Regulation within the limits of the questions posed by the referring court.

It is yet another question whether the Constitutional Court should have made its own referral for a preliminary ruling in the two cases. Although it is obvious that the Constitutional Court missed this opportunity to resolve the legal problem by means of a direct dialogue with the CJEU, it must be noticed, that the main problem was that the Constitutional Court did not consider EU law in the first decision conferring a right to supplementary payment. This was an original sin on the part of the Constitutional Court. The subsequent argumentation was only a consequence of this initial omission. For this reason the Constitutional Court sustained that the whole case remains outside the scope of EU law. At the same time, the preliminary ruling request of the Supreme Administrative Court was not motivated mainly by the care for effectiveness of EU law in the Czech Republic, but it was politically motivated and aimed to challenge the position of the Constitutional Court. As the result of the provocation by the Supreme Administrative Court, the Constitutional Court overreacted and misused ultra vires review. Consequently, the decision of the Court has been broadly criticised

305 The Court indicated that "the ECJ regularly makes use of the institution of amici curiae in proceedings on preliminary questions, especially in relation to the European Commission. In a situation where the ECJ was aware that the Czech Republic, as a party to the proceeding, in whose name the government acted, expressed in its statement a negative position on the legal opinion of the Constitutional Court, which was the subject matter for evaluation, the ECJ' statement that the Constitutional Court was a 'third party' in the case at hand cannot be seen otherwise than as abandoning the principle audiatur et altera pars", para. VII.2.

306 See: J. Komàrek (n. 293).

307 C-213/04 Ewald Burtscher (CJEU, 1 December 2005). 
and rejected by other state organs of the Czech Republic including administrative courts. It shows, that in the era of constitutional pluralism, at least within the EU, the question of the court of last world remains open and that any decision denying authority of the CJEU must be well grounded. It also illustrates problem of 'dual loyalty' of national courts applying EU law. The last, and unfortunately lesser word in the case belonged to the Constitutional Court but its argumentative power is rather weak, so the decision should not be recognised as a precedent.

Although the decision in Slovak Pensions can hardly be recognised as a precedent, it has influenced the perception of EU law in the Czech legal order. In the 2014 Report the Constitutional Court presented the following approach: " $t]$ he Constitutional Court believes that the national constitutional order and EU law are two different systems and two reference criteria, each of which is used autonomously by a different body. The ambits of the Court of Justice of the European Union and the Constitutional Court thus do not overlap, much as the Constitutional Court (driven by the German Solange doctrine) reserved the right to intervene, should the European Union overstep powers delegated to it by the Czech Republic (acting ultra vires), or should it interfere with the material core of the Constitution [...]" and concluded that "the case law of the Court of Justice of the European Union is of limited importance to the application practice of the Constitutional Court due to the mutual non-connectedness of the two judicial systems." ${ }^{308}$ There is no doubt that the statement was connected with Slovak Pensions decision discussed in the subsequent part of the Report. The Constitutional Court tried to show that it was not in the position of competition CJEU basing its argumentation on a dualistic approach towards EU law.

The next example of an Eastern European court, which used dialogue to assert and justify a particular domestic constitutional standard that differs from the solution offered under international human rights law comes from Lithuania. It is the Paksas case of the Lithuanian Constitutional Court of 25 May 2012. ${ }^{309}$ In this case, the Lithuanian Constitutional Court emphasised the need to protect the 'very constitutional identity' of Lithuania when it justified its rejection of ECtHR jurisprudence. The case in question concerned the effects of the ECtHR judgment Paksas v Lithuania, ${ }^{310}$ which criticised an earlier 2004 Constitutional Court's decision ${ }^{311}$ concerning consequences of impeachment

308 Constitutional Court of the Czech Republic (2013) National Report XVIth Congress of the Conference of European Constitutional Courts "Cooperation of Constitutional Courts in Europe - Current Situation and Perspectives" 11.

309 Case 8/2012/05/09/2012 (Lithuanian Constitutional Court, 22 May 2012).

310 Paksas v Lithuania, App. no. 34932/04 (ECtHR, 6 January 2011).

311 Case 24/04 (Lithuanian Constitutional Court, 25 May 2004). 
procedure in the field of electoral rights. ${ }^{312}$ When reviewing this decision, the ECtHR found a violation of the right to vote and stand in parliamentary elections under Art. 3 of the First Protocol to the ECHR. In its subsequent decision of 2012, the Lithuanian Constitutional Court questioned the ECtHR's arguments and set out the limits of the legal consequences of the ECtHR judgments in the Lithuanian legal order based on two arguments. First, the Constitutional Court of Lithuania pointed to the subsidiary nature of the ECHR system and stressed its own exclusive competence to interpret the Constitution of Lithuania. ${ }^{313}$

The Lithuanian Constitutional Court's second argument related to the need to protect the constitutional identity of the state. It observed that there was a close relationship between the impeachment procedure, breach of oath and electoral rights under the Lithuanian Constitution. It stressed that a change of any of these three elements would influence the balance of the Lithuanian constitutional system and the constitutional values behind this system. The Constitutional Court of Lithuania declared the Lithuanian Constitution as the supreme law of the land. It further stated that ECtHR judgments might not serve as a constitutional basis for the reinterpretation of the official constitutional doctrine if such reinterpretation, in the absence of corresponding amendments to the Lithuanian Constitution, affects the essence of the constitutional provision in question. Such reinterpretation based on ECtHR judgments could also not be accepted if it unduly interfered with the values entrenched in the Lithuanian Constitution and undermined the level of protection of fundamental rights offered by it.

The judgment of the Lithuanian Constitutional Court determined limits of effectiveness of the decision of the ECtHR, without questioning its legal value. It is clear for the Court that the decision is binding upon Lithuania, however, in case of conflict between the decision and constitutionally protected values the decision cannot be implemented without change of the Constitution. The Court decided that the harmonious interpretation of the Constitution has its limits if the constitutional identity of the State is to be ensured. Yet, the Court did not use the term; it referred to the "overall constitutional regulation" and the "system of values entrenched in the Constitution" and stressed its own role as a guardian of the constitution. The case constitutes an excellent example of a situation of collision

312 The Lithuanian Constitutional Court held that a person who had been removed from the office of the president for a gross violation of the Lithuanian Constitution or a breach of oath, could never be elected president of the republic or a member of the Seimas (lower chamber of Lithuanian Parliament) again, nor could he/she hold an office for which it was necessary to take an oath in accordance with the Lithuanian Constitution.

313 "Even though the jurisprudence of the European Court of Human Rights, as a source for construction of law, is important also for construction and application of Lithuanian law, the jurisdiction of the said Court does not replace the powers of the Constitutional Court to officially construe the Constitution", para. III.2. 
within a pluralistic system and shows that sometimes resolution of a conflict between a coexisting legal systems within pluralistic legal order cannot be resolved by judges.

The Russian Constitutional Court adopted different approach towards conflicting situation, for the first time in the Markin case concerning paternal leave granted in Russia elusively to female military personnel. After the judgments of the ECtHR ${ }^{314}$ ascertaining violation of Art. 8 ECHR in which the ECtHR criticised the Russian Constitutional Court's decision based on the constitutional protection of motherhood and childhood ${ }^{315}$ as 'unconvincing' and pointed to 'gender prejudices' in the decision, ${ }^{316}$ there was a strong reaction in Russia. ${ }^{317}$ When Mr. Markin applied for the reopening of his case before a regional court in St. Petersburg, in consequence of the ECtHR's ruling, the court referred the case to the Russian Constitutional Court as it was faced with the legal question of how to reconcile contradicting judgments of the Russian Constitutional Court and the ECtHR. In its decision, the Russian Constitutional Court ${ }^{318}$ made sure that it left a backdoor open that would allow it to protect specific domestic solutions in the future, in particular solutions that were based on

314 ECtHR cases: Konstantin Markin v Russia, App. no. 30078/06 (7 October 2010); Konstantin Markin v Russia, App. no. 30078/06 (22 March 2012).

315 Case 187-O-O (Russian Constitutional Court, 15 January 2009). The Constitutional Court stated that: "Owing to the specific demands of military service, non-performance of military duties by military personnel en masse must be excluded as it might cause detriment to the public interests protected by law. Therefore, the fact that servicemen under contract are not entitled to parental leave cannot be regarded as a breach of their constitutional rights or freedoms, including their right to take care of, and bring up, children [...]. Moreover, this limitation is justified by the voluntary nature of the military service contract. By granting, on an exceptional basis, the right to parental leave to servicewomen only, the legislature took into account, firstly, the limited participation of women in military service and, secondly, the special social role of women associated with motherhood. [Those considerations] are compatible with Art. 38(1) of the Constitution of the Russian Federation. Therefore, the legislature's decision cannot be regarded as breaching the principles of equality of human rights and freedoms or equality of rights of men and women, as guaranteed by Art. 19(2) and (3) of the Constitution of the Russian Federation." Translation after the ECtHR Konstantin Markin v Russia (Grand Chamber), para. 34.

316 See: paras 57-59 of the ECtHR Chamber judgment Konstantin Markin v Russia.

317 The President of the Constitutional Court, Valeri Zorkin claimed that the ECtHR had not shown sufficient respect for Russia's sovereignty and its legislature, which was better placed to solve questions related to national security and determining the scope of individual rights in this context. He further declared that the interpretation of the Russian Constitution by the Russian Constitutional Court could not automatically be overridden by an interpretation of the ECHR offered by the ECtHR. See more: W.E. Pomeranz, 'Uneasy Partners: Russia and the European Court of Human Rights' (2012) 3 Human Rights Brief 17; G. Vaypan, 'Acquiescence Affirmed, Its Limits Left Undefined: The Markin Judgment and the Pragmatism of the Russian Constitutional Court vis-à-vis the European Court of Human Rights' (2014) 3 Russian Law Journal 130.

318 Case 27-П/2013 (Russian Constitutional Court, 6 December 2013). 
its own interpretation of the Russian Constitution. The Russian Constitutional Court ruled that the district court was under an obligation to reopen the proceedings after the ECtHR had found a violation of the ECHR by Russia. However, the Court also noted that if a lower court is able to comply with the judgment of the ECtHR only by disregarding an interpretation of the Constitution and a finding of the constitutionality of an ordinary law by the Russian Constitutional Court that was binding on lower courts, the lower court in question is obliged to refer the case to the Russian Constitutional Court. The Constitutional Court will then re-assess its interpretation of the Russian Constitution and/or its finding on the constitutionality of a domestic provision in the light of the ECtHR judgment. The Russian Constitutional Court did not indicate in detail how it would solve such cases. In the case at hand, the decision on $\mathrm{Mr}$ Markin's right to parental leave became redundant because his children attained an age that no longer entitled him to parental leave.

In 2015 a group of Russian Members of Parliament challenged before the Russian Constitutional Court the constitutionality of the 1998 Federal Law "On Ratification of the ECHR" and the 1995 Federal Law "On International Treaties", alongside with a number of procedural norms. The applicants argued that the system of the ECHR and contested rules oblige national courts and other state bodies to unconditional implementation of the ECtHR decisions even if they are contrary to the Russian Constitution and that such a situation leads to a breach of human rights and contradicts the fundamental principles of the constitutional system. The Russian Constitutional Court in the decision of 14 July $2015^{319}$ held that the contested norms do not conflict with the Constitution, however the reasoning of the Court was based on a very strong sovereignty argument supported by the primacy of the Constitution. The Court stressed that any derogation form the obligation to execute ECtHR judgments must remain an exemption since both the Constitution and the ECHR are based on the shared basic values. The Constitutional Court stressed that the system of the ECHR is based on the subsidiarity principle and that the protection granted by the ECtHR is essentially complementary to the national mechanism of judicial protection of human rights. It means that the protection must be granted in the first place by Russian courts including the Constitutional Court and that the result of the judgment of the ECtHR cannot be diminishing the level of protection of a constitutional standard.

The Court considered ECtHR judgments as an integral part of the Russian legal system however under supremacy of the Constitution. The Court held that the Constitution stipulates

319 Case 21-П/2015 (Russian Constitutional Court, 14 July 2015) unofficial translation by Maria Smirnova, <http://transnational-constitution.blogspot.com/2015/08/russian-constitutional-court-decision.html> (access: August 2016). Official summary: <http://www.ksrf.ru/en/Decision/Judgments/Documents/resume\%202015\%2021-\%D0\%9F.pdf> (access: August 2016). 


\begin{abstract}
"impossibility of implementation in the legal system of international treaties participation in which may result in either restriction on rights and freedoms of man and citizen or in violation of constitutional provisions by encroachment on the foundations of the constitutional system of the Russian Federation. Thus, neither the Convention [...] nor the ECtHR judgments based on the Convention and containing an assessment of national legislation or indicating the need to change any of its provisions have capacity to cancel the priority of the Constitution in the Russian legal system." ${ }^{320}$ The Court stressed that conclusion of the international agreement "does not mean repudiation by Russia of its sovereignty." As a result "in situation when the actual content of the judgment of the ECtHR [...] unlawfully from constitutional and legal point of view allude to principles and norms of the Constitution, Russia may, however as a matter of exemption, depart from her obligations when such derogation is the only way to avoid the violation of fundamental principles and norms of the Constitution." ${ }^{221}$
\end{abstract}

The next argument of the Russian Constitutional Court was based on the general international law. The Constitutional Court indicated that in a particular situation a dynamic interpretation of the ECHR by the ECtHR, such that changes the ECHR's meaning and results in a conflict with a national constitution, must be recognised as unlawful in the light of general international law and especially the customary norms of the Vienna Convention on the Law of Treaties. The Constitutional Court argued that an international agreement is binding on the State parties only if it is interpreted according to the rules of 31(1) VCLT. Thus, if the ECtHR decides to deviate from these rules and attribute to the ECHR a meaning contradicting its object and purpose or violating peremptory norms of international law, the State party may refuse to execute the ruling. The Constitutional Court recognised sovereign equality as a jus cogens of general international law. The Court invoked Art. 46(1) of the Vienna Convention and held that it can be recognised as the basis to block the action against the State, which is manifestly contrary to constitutional norms of particular importance. The Court explained that the situation of conflict under consideration concerns a dynamic interpretation by the ECtHR, which had been unforeseeable at the moment of the accession to the Convention.

The Russian Constitutional Court also referred to the practice of the highest courts of European countries: Germany, ${ }^{322}$ Italy, ${ }^{323}$ Austria, ${ }^{324}$ and the United Kingdom, ${ }^{325}$ which also "adhere to the principle of the priority of norms of national constitutions in the execution of the ECtHR judgments." This referral to foreign courts is the most obvious example of an instrumental use of judicial

\footnotetext{
320 See: para. 2.2 .

321 See: para. 2.2 .

322 German Constitutional Court cases: Görgülü 2 BvR 1481/04 (14 October 2004); Solange I 2 BvL 52/71 (29 May 1974).

323 Italian Constitutional Court cases: 264/12 (19 November 2012); 234/14 (22 October 2014).

324 Case B 267/86 (Austrian Constitutional Court, 14 October 1987).

325 Case (2013) UKC 63 (The Supreme Court of the United Kingdom, 16 October 2013).
} 
dialogue. It must be recalled, that the Russian Constitutional Court usually does not refer to other national courts, which means that we have to do with exceptional practice aimed at a specific goal. This aim was to prove that adopted approach is nothing special within the society of state-parties to the ECHR. However an analogy between findings of the Russian Constitutional Court and courts invoked by it is doubtful and misleading. The main problem discussed by national highest courts was how the judgement of the ECtHR should be implemented in terms of direct applicability of the ECHR and decisions of ECtHR. The courts declaring an international decisions non-executable but just with regard to unconstitutionality or legal impossibility for other reasons, of given modality of enforcement ${ }^{326}$ and did not call into question legally binding force of ECtHR decisions.

326 The German Federal Constitutional Court in Görgülü, (n. 34) set up constitutional limits of implementation of the judgments of the ECtHR and placed the Convention in German legal order at the level of regular legislation. However the Federal Constitutional Court has never put into question legally binding force of the judgments of the ECtHR but converted their direct effect. In other words, the German Federal Constitutional Court consider how the judgment should be implemented not whether it should be implemented. Moreover, Security detention I/ 2 BvR 233/08 (Federal Constitutional Court, 4 May 2011), the Court held that Fundamental Law should be interpreted in the light of the Convention and its development by the ECtHR. According to the Court it should be done though transposition of European standard into domestic legal order and held that "It is true that at national level, the European Convention on Human Rights ranks below the Basic Law. However, the provisions of the Basic Law are to be interpreted in a manner that is open to international law (völkerrechtsfreundlich). At the level of constitutional law, the text of the Convention and the case law of the European Court of Human Rights serve as interpretation aids for the determination of the contents and scope of the fundamental rights and of rule-of-law principles enshrined in the Basic Law. An interpretation that is open to international law does not require the Basic Law's statements to be schematically aligned with those of the European Convention on Human Rights but requires its valuations to be taken on to the extent that this is methodically justifiable and compatible with the Basic Law's standards." Cf. F. Hoffmeister, 'Germany: Status of European Convention on Human Rights in Domestic Law' (2006) 4 I-CON 722, 729; A. Seibert-Fohr, M.E. Villiger (eds), Judgments of the European Court of Human Rights - Effects and Implementation (Nomos 2014), p. 267. In case of the High Court of the United Kingdom the main question concerns the limits of obligation of the British courts stemming from the Human Rights Act to "take into account Strasbourg case law" "so far as it is possible to do so", to read and give effect to legislation in a way which is compatible with the Convention rights. The referred judgement thus concerns judicial enforcement of the ECtHR decision and not legally binding force of it and general obligation of execution of the judgment. In contrast to the legal consequences of the judgment of the Russian Constitutional Court, the exclusion of judicial implementation of the judgement by the High Court in particular case does not mean that the judgement is non-executable at all. The High Court expressly stated that implementation of the judgment belongs to the Parliament. See the discussion concerning problems with implementation of Hirst: E. Bates, 'Analysing the Prisoner Voting Saga and the British Challenge to Strasbourg' (2014) 14 Human Rights Law Review, p. 503. Reference to Italian experience seems to be missed since in the decision of 2012 the Italian Constitutional Court clearly stated that: "when fundamental rights are at issue, respect for international obligations cannot in any 
The main outcome of above discussed decisions of the Constitutional Court is reservation of the 'right to object' in most exceptional cases. The Court declared willingness to pursue 'dialogue and constructive engagement. ${ }^{327}$ However, the argumentation of the Court based on the constitutionally determined state sovereignty protected, according to the Court, by the equal sovereignty principle such as jus cogens norm of international law leaves no room for further negotiations in a situation of a conflict. The Court retained the competence to make a final decision as to the implementation of the ECtHR judgements in two kinds of constitutional proceedings: the review of the constitutionality of legislation which was found by the ECtHR contrary to the Convention (any court reconsidering a case on the basis of a decision of the ECtHR is obliged to submit legal question to the Constitutional Court $)^{328}$ and the interpretation of the Constitution in cases brought by the President or the Government of the Russian Federation when they consider that implementation of particular decision of the ECtHR can violate the Constitution.

As a consequence of the above discussed case and also in response to subsequent judgements of the ECtHR especially in Anchugov \& Gladkov ${ }^{329}$ and Yukos ${ }^{330}$ the amendment to the Federal constitutional law on the Constitutional Court of Russian Federation ('Amendment') was adopted in December 2015. The new law extended powers of the Constitutional Court and entitled it, upon a request by the President or the government, to review a contradiction between the provisions of a treaty as interpreted by a treaty body and the provisions of the Constitution, and to declare decisions of international courts as 'unenforceable'. It should be noticed that the European Commission for Democracy through Law (Venice Commission) evaluated the Amendment. The Commission held that it is not against international law to empower the Constitutional Court to control the conformity with the Constitution of decisions of international bodies. However, it is contrary to international law, especially Art. 46 of the ECHR and customary rules stemming from Art. 26 and 27 of the Vienna Convention on Law of Treaties of 1969, that a negative result of the constitutionality review makes the judgment 'unenforceable' and prevents the execution of the judgment in any manner in Russia.

In April 2016 the Russian Constitutional Court, upon request of the Ministry of Justice, resolved another case concerning enforcement of the decision of the

case constitute grounds for a reduction in protection of compared to whose already available under national law, but on the contrary may and must constitute an effective instruments for expanding such protection." The constitutional Court also stressed that ordinary courts are obliged to verify conformity of national law with the ECHR.

327 The Russian Constitutional Court declared that "in the resolution of such conflicts it is necessary not to seek self-isolation, but proceed from the necessity of dialogue and constructive engagement. Only in this way can a truly harmonious relationship between the legal systems in Europe be built, based on mutual respect rather than submission."

328 See: Art. 125(4) of the Constitution of the Russian Federation.

329 Anchugov and Gladkov v Russia, App. nos 11157/04 and 15162/05 (ECtHR, 4 July 2013).

330 Neftyanaya Kompaniya Yukos v Russia, App. no. 14902/04 (ECtHR, 31 July 2014). 
ECtHR. ${ }^{331}$ The case originated in Anchugov and Gladkov v Russia judgment in which the ECtHR found that the Russian Constitution, providing for general ban depraving prisoners right to vote or to stand for election, violated voting rights granted in Protocol 1(3) of the ECHR by Russian law, and Art. 32(3) ${ }^{332}$ of the Russian Constitution. Taking into account a possible constitutional dimension of its own decision, the ECtHR indicated that "[i]n the present case, it is open to the respondent Government to explore all possible ways in that respect and to decide whether their compliance with Art. 3 of Protocol No. 1 can be achieved through some form of political process or by interpreting the Russian Constitution by the competent authorities - the Russian Constitutional Court in the first place - in harmony with the Convention in such a way as to coordinate their effects and avoid any conflict between them."

The Russian Constitutional Court, using new powers and broadly referring to the previous decision of 2015, deemed execution of a judgement in Anchugov and Gladkov as to both general and individual measures impossible. Although the Court employed in its argumentation pluralistic vocabulary (mainly judicial dialogue, constitutional identity, mutual trust), the outcome of the judgement is far from being pluralist, since the Court determined that there was a complete impossibility of execution of the ECtHR decision. The execution was excluded by the Court not only in the light of the Russian Constitution, but also from the point of view of international public law, especially the norms of the law of treaties. Moreover, the findings of the ECtHR with regard to existing European standard were considered as unjustified in the light of both previous ECtHR decisions and development of protection of right to vote in the State parties to the ECHR. In consequence the Court held that

[i]n the Judgment in the case of Anchugov and Gladkov $v$ Russia the European Court of Human Rights attributed to Art. 3 of Protocol No. 1 to the Convention the meaning, implicitly contemplating alteration of Art. 32 (Section 3) of the Constitution of the Russian Federation, to which Russia as a High Contracting Party to the multilateral international treaty, which is the Convention for the Protection of Human Rights and Fundamental Freedoms, gave no consent during its ratification, so far as assumed (including bearing in mind absence of any objections on the part of the Council of Europe) that Art. 32 (Section 3) of the Constitution of the Russian Federation and Art. 3 of Protocol No. 1 to the Convention did not contradict each other. ${ }^{333}$

331 Case 12-П/2016 (Russian Constitutional Court, 19 April 2016). See also comments: I. Nuzov, Russia's Constitutional Court Declares Judgment of the European Court "Impossible" to Enforce (Int'l J. Const. L. Blog 2016), <http://www.iconnectblog.com/2016/04/russias-constitutional-court-declares-judgment-of-the-european-court-impossible-to-enforce> (access: July 2016).

332 Art. 32(3) of the Russian Constitution "citizens detained in a detention facility pursuant to a sentence imposed by a court' to vote or to stand for election."

333 See: para. 4.2. 
This statement means that any further discussion on an imperative ban, according to which all convicted persons serving sentence of deprivation of liberty defined by the criminal law have no electoral rights with no exception, is impossible. The Court even denied payment of just satisfaction adjudicated by the ECtHR, which means general depravation of any legal force of this decision. The suggested possibility of further implementation of the judgment affected by the interpretation of terms 'sentence imposed by the court', 'detained' and 'detention facility', seems to be unsatisfactory in the light of the outcome of the judgment.

The judgement of the Constitutional Court seems to be a dangerous precedent within the system of the ECHR. One must agree that Russia has adopted a policy of partial or à la carte compliance. ${ }^{334}$ It must be noticed that there is a clear position that withdrawal from the Convention is not an option. Rather, it is expected by the Russian authorities that the European system is to be modified with a due regard to the Russian sovereign will determined not in objective way on the basis of the content of the ECHR as international treaty binding upon the Russian Federation but as defined subjectively in the Russian Constitution as interpreted by the Russian Constitutional Court. ${ }^{335}$ It is stressed that

the question is not validity or invalidity for Russia of an international treaty as a whole, but simply of the impossibility to implement its provision in the interpretation attributed to it by an authorized intergovernmental body within the framework of consideration of a specific case, to the extent to which this interpretation has rendered this provision concrete in such a way that it has come into conflict with the provisions of the Constitution of the Russian Federation. ${ }^{336}$

Valeri Zorkin, the President of the Constitutional Court even pointed out that "it is not in the contradiction to the European Court of Human Rights, but, on the contrary, it is based on the aspiration to safeguard ourselves from situations,

334 C. Hillebrecht, Domestic Politics and International Human Rights Tribunals: The Problem of Compliance (Cambridge University Press 2016), p. 113.

335 As the Council of Europe Secretary General Thorbjørn Jagland noticed "our states have consistently demonstrated that perceived tensions between the Convention and core constitutional principles can be resolved without open conflict. This is the only way to preserve our common, legal pan-European space. The alternative is a blatant challenge to the binding effect of the European Court's judgments, which would mark the beginning of the end for our unique human rights protection system. I trust that this is not the intention of the Russian Federation, nor of any other State or any institution in Europe." Speech during the conference held in Sankt Petersburg in 2015, <http://www.coe.int/en/web/secretary-general/speeches/-/asset_publisher/gFMvlOSKOUrv/content/international-conference-enhancing-national-mechanisms-for-effective-implementation-of-the-european-convention-on-human-rights-> (access: May 2016).

336 V. Zorkin, 'Challenges of Implementation of the Convention on Human Rights', <http://www. ksrf.ru/en/News/Documents/Report\%20for\%2022\%200ctober.docx> (access: June 2016). 
fraught with serious complication of the relations of Russia with the ECtHR and with the Council of Europe as a whole. The question regards the situations when the ECtHR decisions, intruding into the sphere of the national sovereignty of Russia, are fraught with more substantial violations of rights of Russian citizens than those, which the Strasbourg Court is objecting to. As a matter of fact, the Constitutional Court, which possesses of a large experience of constructive interaction and mutually respectful dialogue with the ECtHR, has taken upon itself the burden of settlement of conflicts of this sort." ${ }^{\text {"37 }}$

All the above-mentioned explanations employ pluralistic vocabulary, however, the outcome of the judgment is in obvious opposition to the idea.

\section{Concluding Remarks}

The CEE Constitutional Courts, just as other European courts, face the authority of international courts. Since constitutions of these states incorporate international treaty regimes (by means of a general clause as a part of international law like in Czech Republic, Lithuania, Poland, Russia or Ukraine or by specific incorporation like in Hungary) authority of the highest courts established within this regimes must be taken into account by constitutional courts not only in the process of application of international law but also in interpretation of national constitutions and other acts of internal law. The ECC constitutional Courts have built their own relation with international courts on the basis of international obligations of the State and its constitutional framework. Since in all states under consideration there is a strong sovereignty dimension in constitutional provisions connected with supremacy of the constitution as the highest law of the land it was necessary to interpret national constitutions with due openness to international law and revision of an absolute understanding of state sovereignty. Participation in international organisations and undertaking international obligations is seen by the courts as a means of execution of sovereignty, and not as its limitation.

In practice, constitutional courts are in the position to rather avoid conflict with the highest courts of other legal orders. They do so through consistent interpretation of their own constitutions, giving due consideration to the decisions of international courts and building up the court-to-court relations including own scope of jurisdiction under national law. Constitutional courts use judicial dialogue, especially but not exclusively with the ECtHR and CJEU, to achieve this purpose. In the field of human rights protection the legally binding nature of the ECHR

337 Ibidem. 
is not the only reason of such practice. The jurisprudence of the ECtHR is recognized as an indicator of established European standards of protection of human rights. That's why constitutional courts refer to the case law of the ECtHR not only when applying the ECHR but also in the process of interpretation of national law. For the same reason the constitutional courts in difficult cases broadly refer also to practice of foreign courts. Such attitude seems to confirm that courts recognize themselves as members of community of judges ensuring, within a pluralistic legal community, the effective protection and preservation of universal values.

The Constitutional Courts of Czech Republic, Hungary, Lithuania and Poland clearly distinguish scope of their own jurisdiction from jurisdiction of the ECtHR and the CJEU. While they are solely responsible for interpretation and application of the Constitution including review of constitutionality of any applicable law, the European Courts have exclusive power to decide on interpretation of particular international treaties as well as on violation of treaty obligations. This attitude makes the coexistence of different autonomous constitutional orders possible even in conflict situation. However, the courts proclaimed constitutional identity as a boundary beyond which the influence of the external coexisting legal orders on their constitutions is not permissible.

The ECC constitutional Courts preserve their own function as guardians of national constitutions, which means that also implementation of decisions of international courts may be subject of constitutionality review. The approach of the Czech, Lithuanian, Hungarian and Polish Constitutional Courts is similar to this adopted by the CJEU in Kadi. ${ }^{338}$ All international obligations of a State must be performed in conformity with its constitution. However, even if execution of some means of the judgment of a European court is impossible in the light of the national constitution in force, like in Paksas case, it does not mean that it is not possible at all. The distinction between (an indirect) control of constitutionality of a decision of international court and a control of its validity is crucial for constitutional pluralism, since it makes dialogue (in the meaning of both speaking and listening) possible. It also shows that not only common understandings but also real differences are possible. It also shows that judicial practice, even based on due mutual respect, is not able to resolve all problems of complex reality of constitutional pluralism. Sometimes intervention of other, political, bodies is necessary to avoid conflict. As it was indicated at the beginning of the paper, a concept of a dialogue does not mean everyone at the table agree with one another and pluralism involves the commitment to being at the table - with one's commitments. Slovak Pensions shows that lack of due consideration of the authority of the highest court of other legal order and lack of will to engage in a dialogue at the beginning may result in exclusion of participation in further discussion. In case of Russia the argument of state sovereignty as jus cogens norm of international law evocable against a treaty

338 C-402/05 P and C-415/05 P Kadi v Council and Commission (CJEU, 3 September 2008). 
obligation shows that perception of international law in Russia differs from other CEE states. ${ }^{339}$

The practice of the CEE constitutional courts shows also that the line between dualism and pluralism is fluent and nuanced. As in case of practices of Western European courts one may wonder whether argumentation based on mutual trust, friendly coexistence of legal systems and dialogue amounts to the constitutional pluralism or is it simply dualism cloaked as pluralism. ${ }^{340}$

339 It must be emphasised that a strong belief that state sovereignty is the fundamental principle in international law is characteristic for Russian understanding of international law. In the same time, sovereignty is absolute, indivisible and cannot be limited. It leads to critique of constitutionalisation of international law and very idea of legal pluralism. L. Mälksoo, Russian Approaches to International Law (Oxford University Press 2015) 100.

340 Phrase used by A.L. Paulus with regard to the German Federal Constitutional Court in 'From Dualism to Pluralism: The relationship between international law, European law, and domestic law', [in:] P.H.F. Bekker, R. Dolzer, M. Waibel (eds), Making Transnational Law Work in the Global Economy, Essays in Honour of Detlev Vags (Cambridge University Press 2010), p. 134. 


\section{Bibliography}

\section{Case law}

\section{CJEU}

\section{Court of Justice}

26/62 NV Algemene Transport - en Expeditie Onderneming van Gend \& Loos (5 February 1963)

6/64 Costa v ENEL (15 July 1965)

11/70 Internationale Handelsgesellschaft GmbH (CJEU 17 December 1970)

C-283/81 CILFIT and Lanificio di Gavardo SpA v Ministry of Health (6 October 1983)

C-314/85 FotoFrost (22 October 1987)

C-200/91 The Coloroll Pension Trustees (28 September 1994)

C-424/99 Commission v Austria (27 November 2001)

C-229/00 Commission v Finland (12 June 2003)

C-402/05 P and C-415/05 P Kadiv Council and Commission (3 September 2008)

C-399/09 Marie Landtová v Česká správa socialního zabezpečení (22 June 2011)

Joined cases C-293/12 and C-594/12 Digital Rights Ireland Ltd (8 April 2014)

Joined cases C-92/09 and C-93/09 Volker und Markus Schecke GbR (9 November 2010)

C-370/12 Pringle v Government of Ireland (27 November 2012)

\section{General Court}

T-92/98 Interporc v Commission (7 December 1999)

Joined Cases T-110/03, T-150/03 and T-405/03 Jose Maria Sison v Council of the European Union

(26 April 2005)

\section{ECHR}

Klass and Others $v$ Germany, App. no. 5029/71 (6 September 1978)

Sporrong i Lonnroth $v$ Sweden, App. nos 7151/75 and 7172/75 (29 June 1982)

Xv Belgium, App. no. 8707/79 (13 December 1979)

Soering $v$ United Kingdom, App. no. 14038/88 (7 July 1989)

Quaranta v Switzerland, App. no. 12744/87 (24 May 1991)

Spadea and Scalabrino v Italy, App. no. 12868/87 (28 September 1995)

Schmautzer v Austria, App. no. 15523/89 (10 May 1993)

Imbrioscia $v$ Switzerland, App. no. 13972/88 (24 November 1993)

Scollo v Italy, App. no. 19133/91 (28 September 1995)

Velosa Baretto v Portugal, App. no. 18072/91 (21 November 1995)

Kopp v Switzerland, App. no. 23224/94 (5 March 1998)

Teixeira de Castro v Portugal, App. no. 44/1997/828/1034 (9 June 1998)

Viel v France, App. no. 41781/98 (14 December 1999)

Burdov v Russia, App. no. 59498/00 (7 May 2002) 
Broniowski v Poland, App. no. 31443/96 (22 June 2004)

Edwards and Lewis $v$ the United Kingdom, App. nos 39647/98 and 40461/98 (27 October 2004)

Hutten-Czapska v Poland, App. no. 35014/97 (22 February 2005)

Hutten-Czapska v Poland, App. no. 35014/97 (19 June 2006)

Hutten-Czapska v Poland, App. no. 35014/97 (28 April 2008)

A. Gorodnichev v Russia, App. no. 32275/03 (15 November 2007)

Ramanauskas v Lithuania, App. no. 74420/01 (5 February 2008)

Vajnai v Hungary, App. no. 33629/06 (8 July 2008)

Husák v Czech Republic, App. no. 19970/04 (4 December 2008)

Burdov v Russia II, App. no. 33509/04 (15 January 2009)

Yuriy Nikolayevich Ivanov v Ukraine, App. no. 40450/04 (15 October 2009)

Kohlhofer et Minarik v Czech Republic, App. nos 32921/03, 28464/04 and 5344/05 (15 October 2009)

Nagovitsyn and Nalgiyev $v$ Russia, App. nos 27451/09 and 60650/09 (23 September 2010)

Konstantin Markin v Russia, App. no. 30078/06 (7 October 2010)

Konstantin Markin v Russia, App. no. 30078/06 (22 March 2012)

Paksas v Lithuania, App. no. 34932/04 (6 January 2011)

Ullens de Schooten et Rezabek v Belgium, App. nos 3989/07 and 38353/07 (20 September 2011)

Ananyev and Others $v$ Russia, App. nos 42525/07 and 60800/08 (10 January 2012)

Ilyushkin and Others $v$ Russia, App. nos Requêtes nos 5734/08, 20420/07, 54342/08, 56997/08, 60129/08, 4561/09, 7738/09, 11273/09, 11993/09, 16960/09, 20454/09, 21964/09, 26632/09, 28914/09, 31577/09, 31614/09, 31685/09, 32395/09, 35053/09, 36327/09, 38180/09, 45131/09, $48059 / 09,52605 / 09,56935 / 09,58034 / 09,59761 / 09,1048 / 10$ et 1119/10 (17 April 2012)

Kalinkin and Others $v$ Russia, App. nos 16967/10, 37115/08, 52141/09, 57394/09, 57400/09, 2437/10, $3102 / 10,12850 / 10,13683 / 10,19012 / 10,19401 / 10,20789 / 10,22933 / 10,25167 / 10,26583 / 10$, 26820/10, 26884/10, 28970/10, 29857/10, 49975/10 et 56205/10 (17 April 2012)

Anchugov and Gladkov v Russia, App. nos 11157/04 and 15162/05 (4 July 2013)

Khmel v Russia, App. no. 20383/04 (12 December 2013)

Neftyanaya Kompaniya Yukos v Russia, App. no. 14902/04 (31 July 2014)

Biblical Centre of the Chuvash Republic v Russia, App. no. 33203/08 (12 June 2014)

Varga and others $v$ Hungary, App. nos 14097/12, 45135/12, 73712/12, 34001/13, 44055/13, and 64586/13 (10 March 2015)

Rutkowski v Poland Rutkowski and Others v Poland, App. nos 72287/10, 13927/11 and 46187/11

(7 July 2015)

Gazsó v Hungary, App. no. 48322/12 (16 October 2015)

Vasiliauskas v Lithuania, App. no. 35343/05 (20 October 2015)

\section{ICJ}

Advisory Opinion on the Reservations to the Convention on Genocide (28 May 1951)

Nottebohm Lichtenstein v Guatemala (6 April 1955)

Gabčikovo-Nagymaros Project, Hungary v Slovakia (25 September 1997)

La Grand Germany $v$ United States of America (27 June 2001)

Avena and Other Mexican Nationals, Mexico v United States of America (31 March 2004) 
Armed activities on the territory of the Congo Democratic Republic of the Congo $v$ Rwanda (3 February 2006)

Bosnia and Herzegovina v Serbia and Montenegro (26 February 2007)

\section{ICTY}

IT-95-10 The Prosecutor v Jelisić (14 December 1999)

IT-95-16-T The Prosecutor v Kupreškić and Others (14 January 2000)

IT-98-33 The Prosecutor v Krstić (2 August 2001)

IT-02-60-T The Prosecutor v Blagojević and Jokić (17 January 2005)

IT-03-66-T The Prosecutor $v$ Limaj and Others (November 2005)

\section{ICTR}

ICTR-96-4-T The Prosecutor v Akayesu (2 September 1998)

ICTR-95-1-T Kayishema and Ruzindana (21 May 1999)

ICTR-97-20 The Prosecutor $v$ Semanza (15 May 2003)

ICTR-95-54A-T The Prosecutor $v$ Kamuhanda (22 January 2004)

\section{Austria}

\section{Constitutional Court}

B 267/86 (14 October 1987)

Schmautzer B 821/88 (27 February 1989)

\section{Cyprus}

\section{Supreme Court}

65/2009, 78/2009, 82/2009 and 15/2010-22/2010 (1 February 2011)

\section{Czech Republic}

\section{Constitutional Court}

Pl. ÚS 9/94 (13 September 1994)

Pl. ÚS 33/96 (4 June 1997)

Pl. ÚS 45/97 (25 March 1998)

Pl. ÚS 36/01 (25 June 2001)

Pl. ÚS 15/02 (21 January 2003)

Pl. II. ÚS 405/02 (6 March 2003)

I. ÚS 752/02 (15 April 2003)

Pl. ÚS 44/02 (24 June 2003)

Pl. ÚS 11/04 (25 April 2005)

Pl. ÚS 50/04 (8 March 2006)

Pl. ÚS 50/04 (8 March 2006)

Pl. ÚS 37/04 (26 April 2006) 
Pl. ÚS 66/04 (3 May 2006)

I. ÚS 310/05 (11 November 2006)

Pl. ÚS 36/05 (16 January 2007)

Pl. ÚS 4/06 (20 March 2007)

III. ÚS 2738/07 (24 July 2008)

Pl. ÚS 19/08 (26 November 2008)

Pl. ÚS 154/08 (30 June 2008)

II. ÚS 1009/08 (8 January 2009)

II. ÚS 1945/08 (2 April 2009)

I. ÚS 2553/07 (15 February 2010)

II. ÚS 862/10 (19 May 2010)

III. ÚS 1012/10 (12 August 2010)

Pl. ÚS 14/10 (7 January 2011)

Pl. ÚS 24/10 (22 March 2011)

Pl. ÚS 24/11 (20 December 2011)

II. ÚS 1685/11 (30 November 2011)

Pl. ÚS 5/12 (31 January 2012)

Pl. ÚS 17/11 (5 May 2012)

I. ÚS 2482/13 (26 May 2014)

3 ÚS 1136/13 (27 October 2015)

1 II. ÚS 3626/13 (16 December 2015)

\section{Supreme Administrative Court}

3 Ads 2/2003-112 (26 October 2005)

3 Ads 130/2008 (23 September 2009)

\section{Denmark}

\section{Supreme Court}

Carlsen and Others v Rasmussen I-361/1997 (6 April 1998)

\section{France}

\section{Cour de cassation}

Administration des Douanes $v$ Societe 'Cafes Jacques Vebre' et SARL Wiegel et Cie (8 January 1971)

\section{Constitutional Council}

2007-560 DC (20 December 2007)

\section{Germany}

\section{Constitutional Court}

Internationale Handesgesellschaft GmbH (Solange I) BvL 52/71 (29 May 1974)

1 BvR 1925/80 (26 January 1982) 
BVerfGE 65 (15 December 1983)

Re Wünsche Handelsgesellchaft (Solange II) 2 BvR 197/83 (22 October 1986)

1 BvR 331/85 (24 July 1986)

Hitler T-shirt 1 BvR 680/86 (3 April 1990)

1 BvR 74/92 (9 March 1992)

Brunner v the European Union Treaty 2 BvR 2134 and 2159/92 (12 October 1993)

Görgülü 2 BvR 1481/04 (14 October 2004)

1 BvR 668/04 (27 July 2005)

1 BvR 204/03 (23 March 2006)

BVerfGE 115 (4 April 2006)

1 BvR 150/03 (1 June 2006)

1 BvR 370/07, 1 BvR 595/07 (27 February 2008)

2 BvR 2202/08 (18 May 2009)

Lisbon Treaty 2 BvE 2/08 (German Federal Constitutional Court 30 June 2009)

1 BvR 256/08, 1 BvR 263/08, 1 BvR 586/08 (2 March 2010)

Honeywell (Mangold) 2 BvR 2661/06 (6 July 2010)

Security detention 2 BvR 233/08 (4 May 2011)

2 BvR 1390/12 (12 September 2012)

\section{Hungary}

\section{Constitutional Court}

48/1998 (XI. 23.) AB (18 November 1998)

14/2000 (V. 12.) AB (9 May 2000)

988/E/2000 (7 October 2003)

57/2001 (XII. 5.) AB

22/2003 (IV. 28.) $\mathrm{AB}$

50/2003 (XI. 5.) AB

17/2004 (V. 25.) AB. IV. 1.

1053/E/2005 (16 June 2006)

72/2006 (XII. 15.) (15 December 2006)

6/2007 (II. 27.) AB

20/2007 (III. 29.) AB

281/B/2007 (6 April 2009)

21/B/2008, 154/2008 (XII. 15.) AB (15 December 2008)

$32 / 2008$ (III. 12.)

$61 / 2008$ (IV. 29.)

$76 / 2008$ (V. 29.) (29 May 2008)

87/2008 (VI. 18.) AB

$53 / 2009$ (V. 6.) AB

143/2010 (VII. 14.) AB

61/2011 (12 July 2011)

1/2013 (I. 7.) AB (4 January 2013) 
22/2012 (V.11.) $\mathrm{AB}$

22/2013 (VII. 19.) $\mathrm{AB}$

7/2014 (III. 7.) AB

32/2014 (XI. 3.)

\section{Ireland}

\section{Supreme Court}

Society for the Protection of Unborn Children (Ireland) Ltd. $v$ Grogan (19 December 1989)

Attorney General v X (5 March 1992)

\section{Italy}

\section{Constitutional Court}

74/1958 (20 December 1958)

Frontini v Ministero delle Finanze 183/73 (27 December 1973)

S.p.a. Granital v Amministrazione delle Finanze dello Stato 170 (8 June 1984)

Fragd v Amministrazione delle Finanze dello Stato 232/1989 (21 April 1989)

264/12 (19 November 2012)

234/14 (22 October 2014)

\section{Latvia}

\section{Constitutional Court}

2008-35-01 (7 April 2009)

\section{Lithuania}

\section{Constitutional Court}

22/94 (24 January 1995)

11/99 (7 January 1999)

12/99-27/99-29/99-1/2000-2/2000 (8 May 2000)

24/04 (25 May 2004)

17/02-24/02-06/03-22/04 (14 March 2006)

30/03 (21 December 2006)

47/04 (8 May 2007)

7/04-8/04 (15 May 2007)

47/04 (4 December 2008)

33/06 (27 March 2009)

13/2010-140/2010 (22 December 2011)

$8 / 2012$ (22 May 2012)

31/2011-40/2011-42/2011-46/2011-9/2012-25/2012 (18 March 2014)

26/2014-4/2015 (9 July 2015) 
10/2015 (20 October 2015)

13/2013-34/2014 (29 October 2015)

2/2014 (4 November 2015)

\section{Poland}

\section{Constitutional Court}

K 13/94 (14 March 1995)

P 1/95 (11 September 1995)

P 11/98 (12 January 2000)

P 8/00 (4 October 2000)

K 33/02 (19 December 2002)

K 12/03 (18 February 2004)

SK 29/04 (6 December 2004)

P 1/05 (27 April 2005)

K 18/04 (11 May 2005)

K 17/05 (20 March 2006)

P 37/05 (19 December 2006)

K 41/05 (2 June 2007)

K 51/07 (27 June 2008)

K 38/07 (3 July 2008)

Kp 3/08 (18 February 2009)

K 54/07 (23 June 2009)

SK 48/05 (9 July 2009)

K 63/07 (15 July 2009)

U 10/07 (2 December 2009)

Kp 8/09 (3 December 2009)

SK 52/08 (9 June 2010)

SK 26/08 (5 October 2010)

P 29/09 (18 November 2010)

K 32/09 (24 November 2010)

SK 45/09 (16 November 2011)

SK 11/12 (23 October 2012)

K 19/11 (3 June 2014)

K 23/11 (30 July 2014)

P 26/11 (15 October 2013)

K 33/12 (236 June 2013)

K 6/13 (11 March 2014)

K 44/12 (18 September 2014)

K 28/13 (21 September 2015)

K 39/12 (20 January 2015)

K 61/13 (7 July 2015)

SK 32/14 (22 September 2015) 
K 5/15 (17 November 2015)

K 47/15 (9 March 2016)

\section{Supreme Court}

I CK 323/02 (21 November 2003)

\section{Romania}

\section{Constitutional Court}

1258 (8 October 2009)

\section{Russia}

\section{Constitutional Court}

4-П (4 February 1996)

86-O (14 July 1998)

8-П (16 May 2000)

11-П (27 June 2000)

1-П (25 January 2001)

11-П (19 June 2002)

14-П (18 July 2003)

8-П (14 July 2005)

2-П (5 February 2007)

187-O-O (15 January 2009)

5-П (17 March 2009)

4-П (26 February 2010)

6-П (25 April 2011)

16-П (14 July 2011)

27-П/2011 (6 December 2011)

30-П (21 December 2011)

29-П (30 November 2012)

27-П/2013 (6 December 2013)

21-П/2015 (14 July 2015)

6-П/2014 (19 March 2014)

6-П/2015 (31 March 2015)

12-П/2016 (19 April 2016)

\section{Slovakia}

\section{Constitutional Court}

Pl. ÚS 15/03 (11 February 2004) 


\section{United Kingdom}

\section{Supreme Court}

Manchester City Council v Pinnock (Nos 1 and 2) [2011] 2 AC 104 (30 November 2010)

[2013] UKC 63 (16 October 2013)

\section{Ukraine}

\section{Constitutional Court}

9-rp/97 (25 December 1997)

11-rp/99 (29 December 1999)

19-rp/2004 (1 December 2004)

6-rp/2007 (9 July 2007)

2-rp/2008 (29 January 2008)

20-rp/2008 (8 October 2008)

8-rp/2010 (11 March 2010)

17-rp/2010 (29 June 2010)

1 -rp/2012 (18 January 2012)

10-rp/2012 (18 January 2012)

5-rp/2012 (13 March 2012)

2-rp/2014 (14 March 2014)

3-rp/2015 (8 April 2015)

4-rp/2014 (22 April 2014)

\section{United States of North America}

\section{US Illinois Supreme Court}

Society $v$ Kohrig 62719-24, 498 N.E. 2d 1158 (1 October 1986)

\section{US Iowa Supreme Court}

State $v$ Hartog Ref. No. 88-383, 440 N.W. 2d 852 (17 May 1989)

\section{US Washington Supreme Court}

State v Eckblad 74109-3, 152 Wn. 2d 515, 98 3d 1184 (14 October 2004)

\section{References}

\section{Books}

Allott P., The Emerging Universal Legal System in New Perspectives on the Divide Between National and International Law (Oxford University Press 2007)

Bobek M., Comparative Reasoning in European Supreme Courts (Oxford University Press 2013) 
Burkov A.L., The Impact of the European Convention on Human Rights on Russian Law. Legislation and Application in 1996-2006 (ibidem-Verlag, Stuttgart 2007), http://sutyajnik.ru/documents/4237.pdf (access: between March 2014 and May 2016)

Claes M., The National Courts Mandate in the European Constitution (Hart Publishing 2006)

Czarnota A., Krygier M., Sadurski W. (eds), Spreading Democracy and the Rule of Law? The Impact of EU Enlargement for the Rule of Law, Democracy and Constitutionalism in Post-Communist Legal Orders, Constitutional Evolution in Central and Eastern Europe: Expansion and Integration into the EU (Springer 2006)

Habermas J., Between Facts and Norms. Contributions to a Discourse Theory of Law and Democracy translated by William Rehg (The MIT Press 1996)

Hammer L., Emmert F. (eds), The European Convention on Human Rights and Fundamental Freedoms in Central and Eastern Europe (Eleven International Publishing 2012)

Hart H.L.A., The Concept of Law (Oxford University Press 1997)

Hillebrecht C., Domestic Politics and International Human Rights Tribunals: The Problem of Compliance (Cambridge University Press 2016)

Maggs P.B., Schwartz O., Burnham W., Law and Legal System of the Russian Federation (Juris Publishing 2015)

Mälksoo L., Russian Approaches to International Law (Oxford University Press 2015)

Prochazka R., Mission Accomplished on Founding Constitutional Adjudication in Central Europe (Central European University Press 2002)

Rosenfeld M., The Identity of the Constitutional Subject: Selfhood, Citizenship, Culture, and Community (Routledge 2010)

Tatham A.F., Central European Constitutional Courts in the Face of EU Membership: The Influence of the German Model in Hungary and Poland. The Influence of the German Model in Hungary and Poland (Martinus Nijhoff Publishers 2013)

Visser de M., Constitutional Review in Europe (Hart Publishing 2015)

\section{Books Sections}

Búrca de G., 'The ECJ and the international legal order: A re-evaluation', [in:] Búrca de G., Weiler J.H.H., The Worlds of European Constitutionalism (Oxford University Press 2011) 105

Čepas A., 'Preface', [in:] Human Rights in Lithuania (NAUJOS SISTEMOS 2005)

Chronowski N., Drinóczi T., Ernszt I., 'Hungary', [in:] Shelton D. (ed.), International Law and Domestic Legal Systems. Incorporation, Transformation and Persuasion (Oxford University Press 2011) 278

Collins R., 'Classical legal positivism in international law revisited', [in:] Kammerhofer J., D’Aspremont J. (eds), International Legal Positivism in a Post-Modern World (Oxford University Press) 24

Fuentes C.I., Provost R., Walker S.G., 'E Pluribus Unum - Bhinneka Tunggal Ika? Universal Human Rights and the Fragmentation of International Law', [in:] Provost R., Sheppard C. (eds), Dialogues on Human Rights and Legal Pluralism (Springer 2013) 38

Gaja G., 'Dualism: A Review', [in:] Nijman J., Nollkaemper A. (eds), New Perspectives on the Divide between National and International Law (Oxford University Press 2007) 53 
Klabbers J., Piiparinen T., 'Normative Pluralism: An Exploration', [in:] Klabbers J., Piiparinen T. (eds), Normative Pluralism and International Law: Exploring Global Governance (Cambridge University Press 2013) 13

Kovács P., 'International Law in the Recent Jurisprudence of the Hungarian Constitutional Court: Opening of a New Tendency?' in: Seibert-Fohr A., Villiger M.E. (eds), Judgments of the European Court of Human Rights - Effects and Implementation (Nomos 2014) 251

Kowalik-Bańczyk K., 'Sending Smoke Signals to Luxembourg - the Polish Constitutional Tribunal in Dialogue with ECJ', [in:] Claes M., Visser de M., Popelier P., Van de Heyning C. (eds), Constitutional Conversation in Europe. Actors, Topics and Procedures (Intersentia Publishing Ltd. 2012) 267

Kowalik-Bańczyk K., 'Report on Poland', [in:] Martinico G., Pollicino O. (eds), The National Treatment of the ECHR and EU Law. A Comparative Constitutional Perspective (2010) 329

Krisch N., 'The case for pluralism in postnational law, [in:] Búrca de G., Weiler J.H.H., The Worlds of European Constitutionalism (Oxford University Press 2011) 203

Mare de la T., Donnelly C., 'Preliminary Rulings and EU Legal Integration: Evolution and Stasis', [in:] Craig P., Búrca de G. (eds), The Evolution of EU Law (Oxford University Press 2011) 363

Molek P., 'The Czech Constitutional Court and the Court of Justice: Between Fascination and Securing Autonomy', [in:] Claes M., Visser de M., Popelier P., Van de Heyning C. (eds), Constitutional Conversation in Europe. Actors, Topics and Procedures (Intersntia Publishing Ltd. 2012) 131

Nijman J., Nollkaemper A., 'Beyond Divide, [in:] Nijman J., Nollkaemper A. (eds), New Perspectives on the Divide Between National and International Law (Oxford University Press 2007) 341

Lachmayer K., 'The Possibility of International Constitutional Law. A Pluralistic Approach towards Constitutional Claw and Constitutional Comparison', [in:] Riberi P., Lachmayer K. (eds), Philosophical or Political Foundation of Constitutional Law?: Perspectives in Conflict (Nomos Publishing 2014) 283

Macdonald R.A., 'Pluralistic Human Rights? Universal Human Wrongs?', [in:] Provost R., Sheppard C. (eds), Dialogues on Human Rights and Legal Pluralism (Springer 2013) 15

Maduro M.P., 'Courts and Pluralism: Essay on a Theory of Judicial Adjudication in the Context of Legal and Constitutional Pluralism', [in:] Dunoff J.L., Trachtman J.P. (eds), Ruling the World? Constitutionalism, International Law, and Global Governance (Cambridge University Press 2009) 356

Maduro M.P., 'Contrapuntal Law: Europe’s Constitutional Pluralism in Action', [in:] Walker N. (ed.), Sovereignty in Transition (Hart Publishing 2003) 501

Štruma P., 'Human Rights in a New EU Member State: The Czech Example', [in:] Arnold R. (ed.), Universalism of Human Rights (Springer 2013) 357

Perju V., 'Constitutional Transplants, Borrowing, and Migrations', [in:] Rosenfeld M., Sajó A. (eds), The Oxford Handbook of Comparative Constitutional Law (Oxford University Press 2012) 1304

Peters A., 'Membership in the Global Constitutional Community', [in:] Klabbers J., Peters A., Ulfstein G. (eds), The Constitutionalisation of International Law (Oxford University Press 2009) 153

Peters A., 'The Globalization of State Constitutions', [in:] Nijman J., Nollkaemper A. (eds), New Perspectives on the Divide Between National and International Law (Oxford University Press 2007) 251 
Rosenfeld M., Sajó A., 'Introduction', [in:] Rosenfeld M., Sajó A. (eds), Oxford Handbook of Comparative Constitutional Law (Oxford University Press 2012) 1

Safjan M., 'Central \& Eastern European Constitutional Courts Facing New Challenges - Ten Years of Experience', [in:] Bobek M. (ed.), Central European Judges Under the European Influence. The Transformative Power of the EU Revisited (Hart Publishing 2015) 375

Stone Sweet A., Keller H., 'The Reception of the ECHR in National Legal Orders', [in:] Keller H., Stone Sweet A. (eds), A Europe of Rights. The Impact of the ECHR on National Legal Systems (Oxford University Press 2008) 3

Štruma P., 'Human Rights in a New EU Member State: The Czech Example', [in:] Arnold R. (ed.), Universalism of Human Rights (Springer 2013) 357

Tatham A.F., “Keeping Faith” The Trials and Tribulations of the Hungarian Constitutional Court in Following its European Vocation', [in:] Bobek M. (ed.), Central European Judges Under the European Influence. The Transformative Power of the EU Revisited (Hart Publishing 2015) 349

Trochev A., 'Russia's Constitutional Spirit: Judge-Made Principles in Theory and Practice', [in:] Smith G.B., Sharlet R. (eds), Russia and its Constitution: Promise and Political Reality (Martinus Nijhoff Publishers 2008) 53

Ulfstein G., 'The International Judiciary', [in:] Klabbers J., Peters A., Ulfstein G. (eds), The Constitutionalisation of International Law (Oxford University Press 2009) 142

Walker N., 'Post-Constituent Constitutionalism? The Case of the European Union', [in:] Laughlin M., Walker N. (eds), The Paradox of Constitutionalism: Constituent Power and Constitutional Form (Oxford University Press 2007) 247

Wildhaber L., 'Rethinking the European Court of Human Rigths', [in:] Christoffersen J., Rask Madsen M. (eds), The European Court of Human Rights. Between Law and Politics (Oxford University Press 2011) 222

Wildhaber L., 'Pilot Judgments in Cases of Structural or Systemic Problems on the National Level', [in:] Wolfrum R., Deutsch U. (eds), The European Court of Human Rights Overwhelmed by Applications: The Problems and Possible Solutions (Springer-Verlag 2009)

Wójtowicz K., Constitutional Courts and European Union Law (Wydawnictwo Sejmowe 2014)

\section{Articles}

Albi A., 'Supremacy of EC Law in new Member States. Bringing Parliaments into the Equation of "Cooperative Constitutionalism"' (2007) 3 European Constitutional Law Review 25

Anagnostaras G., 'Activation of the Ultra Vires Review: The Slovak Pensions Judgment of the Czech Constitutional Court' (2013) 14 German Law Journal 959

Avbelj M., Komárek J., 'Four Visions of Constitutional Pluralism' (2008) 4 European Constitutional Law Review 524

Barents R., 'The Precedence of EU Law from the Perspective of Constitutional Pluralism' (2009) 5 European Constitutional Law Review 421

Bates E., 'Analysing the Prisoner Voting Saga and the British Challenge to Strasbourg' (2014) $14 \mathrm{Hu}-$ man Rights Law Review 503

Bogdandy von A., 'Pluralism, direct effect, and the ultimate say: On the relationship between international and domestic constitutional law' (2008) 6 International Journal of Constitutional Law 397 
Cartabia M., 'Europe and Rights: Taking Dialogue Seriously' (2009) 5 European Constitutional Law Review 5

Chronowski N., Csatlós E., 'Judicial Dialogue or National Monologue? The International Law and Hungarian Courts' (2013) 1 ELTE Law Journal 27

The European Court of Human Rights, 'The Past, The Present, The Future' (2007) 22 American University International Law Review 521

Hoffmeister F., 'Germany: Status of European Convention on Human Rights in Domestic Law' (2006) 4 I-CON 722

Komárek J., 'Playing with Matches: The Czech Constitutional Court Declares a Judgment of the Court of Justice of the EU ultra Vires; Judgment of 31 January, Pl. ÚS 5/12 Slovak Pensions XVII' (2012) 8 European Constitutional Law Review 323

Konstadinides T., 'Destroying Democracy on the Ground of Defending It? The Data Retention Directive, the Surveillance State and Our Constitutional Ecosystem' (2011) 36 European Law Review 722

Koroteev K., Golubok S., 'Judgment of the Russian Constitutional Court on Supervisory Review in Civil Proceedings: Denial of Justice, Denial of Europe' (2007) 7 Human Rights Law Review 619

Kowalik-Bańczyk K., 'Should We Polish It Up? The Polish Constitutional Tribunal and the Idea of Supremacy of EU Law' (2005) 6 German Law Journal 1355

Král R., 'Questioning the Recent Challenge of the Czech Constitutional Court to the ECJ' (2013) 19 European Public Law 271

Kühn Z., 'Ultra Vires Review and Demise of constitutional Pluralism. The Czecho-Slovak Pensions Saga, and the Dangers of State Court's Defiance of EU Law' (2016) 1 Maastricht Journal 183

Leach P., Hardman H., Stephenson S., 'Can the European Court's Pilot Judgment Procedure Help Resolve Systemic Human Rights Violations? Burdov and the Failure to Implement Domestic Court Decisions in Russia' (2010) 2 Human Rights Law Review 346

MacCormick N., 'The Maastricht Urteil: Sovereignty Now' (1995) 1 European Law Journal 259

Marks G., Hooghe L., Blank K., 'European Integration from the 1980s: State-centric vs. Multi-level Governance' (1996) 34 Journal of Common Market Studies 341

Martinico G., 'Multiple loyalties and dual preliminarity: The pains of being judge in a multilevel legal order' (2012) 10 I-CON 871

Martinico G., 'Judging in the Multilateral Legal Order: Exploring the Techniques of "Hidden Dialogue' (2010) 21 King's Law Journal 257

Mikeš P., 'Czech Courts and International Law' (2011) 2 Czech Yearbook of International Law 289

Peters A., 'Supremacy Lost: International Law Meets Domestic Constitutional Law' (2009) 3 Vienna Online Journal on International Constitutional Law 170

Pomeranz E., 'Uneasy Partners: Russia and the European Court of Human Rights' (2012) 3 Human Rights Brief 17

Priban I., 'Asking the Sovereignty Question in Global Legal Pluralism: From “Weak” Jurisprudence to "Strong” Socio-Legal Theories of Constitutional Power Operations' (2015) 28 Ratio Juris 33

Rosenfeld M., 'Is Global Constitutionalism Meaningful or Desirable?' (2014) 25 European Journal of International Law 177

Slaughter A.-M., 'A Typology on Transjudicial Communication' (1994) 29 University of Richmond Law Review 106 
Śledzińska-Simon A., 'Constitutional identity in 3D: A model of individual, relational, and collective self and its application in Poland' (2015) 13 I-CON 124

Stone Sweet A., 'Constitutionalism, Legal Pluralism, and International Regimes' (2009) 16 Indiana Journal of Global Legal Studies 621

Vaypan G., 'Acquiescence Affirmed, Its Limits Left Undefined: The Markin Judgment and the Pragmatism of the Russian Constitutional Court vis-à-vis the European Court of Human Rights' (2014) 2 Russian Law Journal 130

Voßkuhle A., 'Multilevel Cooperation of the European Constitutional Courts. Der Europäische Verfassungsgerichtsverbund' (2010) 6 European Constitutional Law Review 175

Walker N., 'The Idea of Constitutional Pluralism' (2002) 65 Modern Law Review 317

Wendel M., 'Lisbon before the Courts: Comparative Perspective' (2011) 7 European Constitutional Law Review 96

Wet de E., 'The International Constitutional Order' (2006) 55 International \& Comparative Law Quarterly 51

Zbíral R., 'A Legal Revolution or Negligible Episode? Court of Justice Decision Proclaimed Ultra Vires' (2012) 49 Common Market Law Review 1457

\section{Other}

Benvenisti E., 'Reclaiming Democracy: The Strategic Uses of Foreign and International Law by National Courts' (2008) 5 Tel Aviv University Law Faculty Papers

Danilenko G., 'Implementation of International Law in Russia and Other CIS States' (1998), <http:// www.nato.int/acad/fellow/96-98/danilenk.pdf> (access: between March 2014 and May 2016)

Krzemińska J., 'Courts as Comparatists: References to Foreign Law in the Case law of the Polish Constitutional Court' (2012) 05 Jean Monnet Working Paper

Nuzov I., 'Russia’s Constitutional Court Declares Judgment of the European Court "Impossible" to Enforce', Int'l J. Const. L. Blog (2016), <http://www.iconnectblog.com/2016/04/russias-constitutional-court-declares-judgment-of-the-european-court-impossible-to-enforce > (access: July 2016)

Sadurski W., 'Partnering with Strasbourg: Constitutionalisation of the European Court of Human Rights, the Accession of Central and East European States to the Council of Europe and the Idea of Pilot Judgments' (2008) 08 Sydney Law School Legal Studies Research Paper

Sadurski W., “'Solange, chapter 3": Constitutional Courts in Central Europe - Democracy - European Union' (2006) 40 EUI Working Paper LAW

Wendel M., 'Comparative Reasoning and the Making of a Common Constitutional Law - The Europe-Decisions of National Constitutional Courts in a Transnational Perspective' (2013) 25 Jean Monnet Working Paper

Zorkin V., Challenges of Implementation of the Convention on Human Rights, <http://www.ksrf.ru/ en/News/Documents/Report\%20for\%2022\%20October.docx> (access: June 2016) 